Prepared in cooperation with the Southwest Tennessee Development District

\title{
Automated Identification of Stream-Channel Geomorphic Features From High-Resolution Digital Elevation Models in West Tennessee Watersheds
}

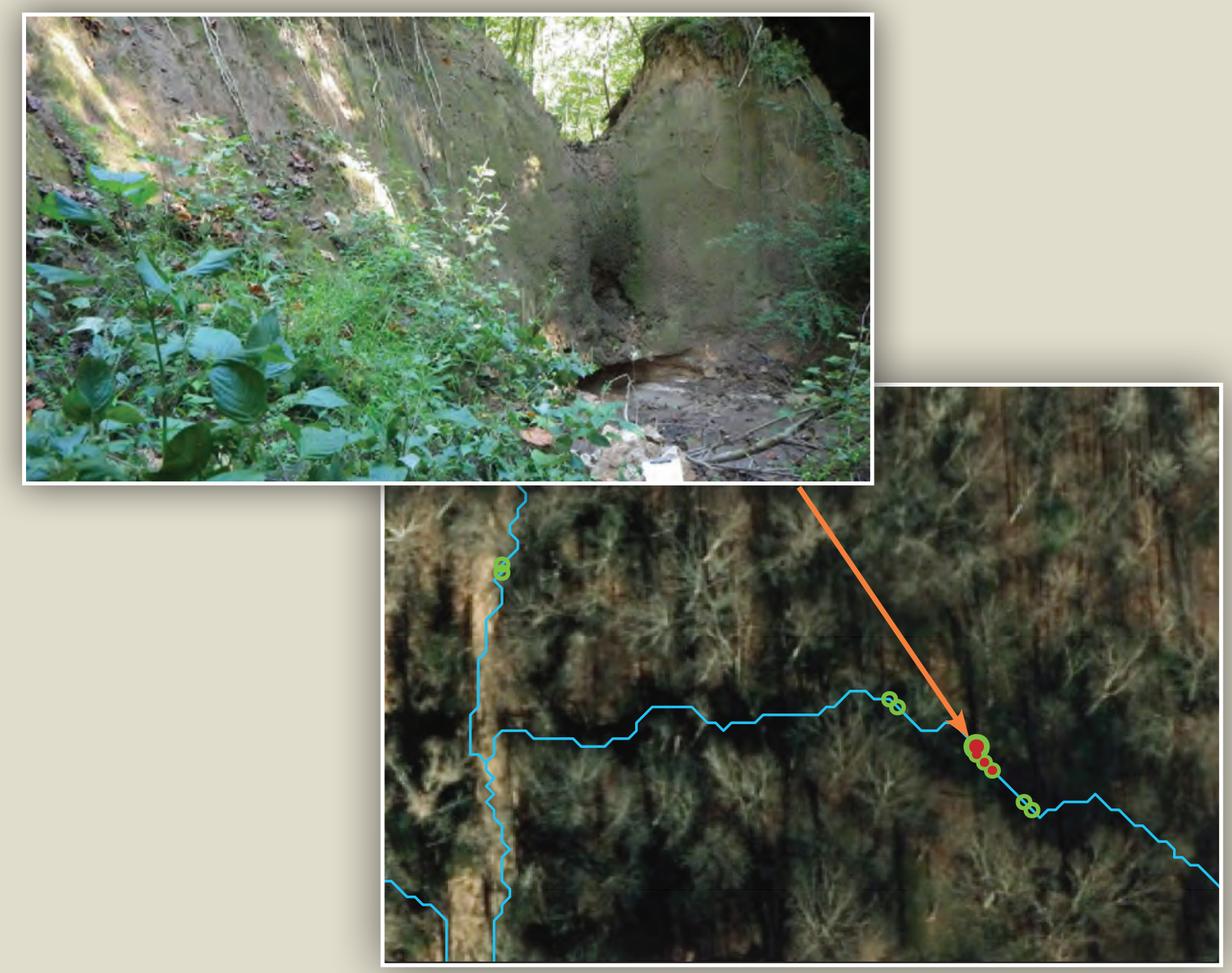

Scientific Investigations Report 2016-5141 
Cover: A head cut 3 meters tall that was not detectable from high-resolution aerial imagery but associated with a flow-network zone of steep slope and high slope-area index, Upper Sandy study area. 


\section{Automated Identification of Stream-Channel Geomorphic Features From High-Resolution Digital Elevation Models in West Tennessee Watersheds}

By Jennifer M. Cartwright and Timothy H. Diehl

Prepared in cooperation with the Southwest Tennessee Development District

Scientific Investigations Report 2016-5141 


\section{U.S. Department of the Interior SALLY JEWELL, Secretary}

\section{U.S. Geological Survey Suzette M. Kimball, Director}

\section{U.S. Geological Survey, Reston, Virginia: 2017}

For more information on the USGS - the Federal source for science about the Earth, its natural and living resources, natural hazards, and the environment—visit http://www.usgs.gov or call 1-888-ASK-USGS.

For an overview of USGS information products, including maps, imagery, and publications, visit http://store.usgs.gov/.

Any use of trade, firm, or product names is for descriptive purposes only and does not imply endorsement by the U.S. Government.

Although this information product, for the most part, is in the public domain, it also may contain copyrighted materials as noted in the text. Permission to reproduce copyrighted items must be secured from the copyright owner.

\footnotetext{
Suggested citation:

http://catalog.loc.gov/

ISSN 2328-031X (print)

ISSN 2328-0328 (online)

ISBN 978-1-4113-4100-5
}

Cartwright, J.M., and Diehl, T.H., 2017, Automated identification of stream-channel geomorphic features from high-resolution digital elevation models in West Tennessee watersheds: U.S. Geological Survey Scientific Investigations Report 2016-5141, 44 p., https://doi.org/10.3133/sir20165141. 


\section{Acknowledgments}

The authors wish to thank Timothy Poole, Park Manager at Pinson Mounds State Archaeological Park, Tennessee Department of Environment and Conservation, Division of State Parks, for facilitating access and providing information for one of the study sites. This report was improved through reviews by Alfred Kalyanapu of Tennessee Technological University and Jeffrey Fore of The Nature Conservancy. The authors are also grateful to Gregg Hileman and David Ladd of the U.S. Geological Survey for assistance with field data collection and postprocessing, technical assistance with field equipment, and valuable technical discussions during the course of the study. 



\section{Contents}

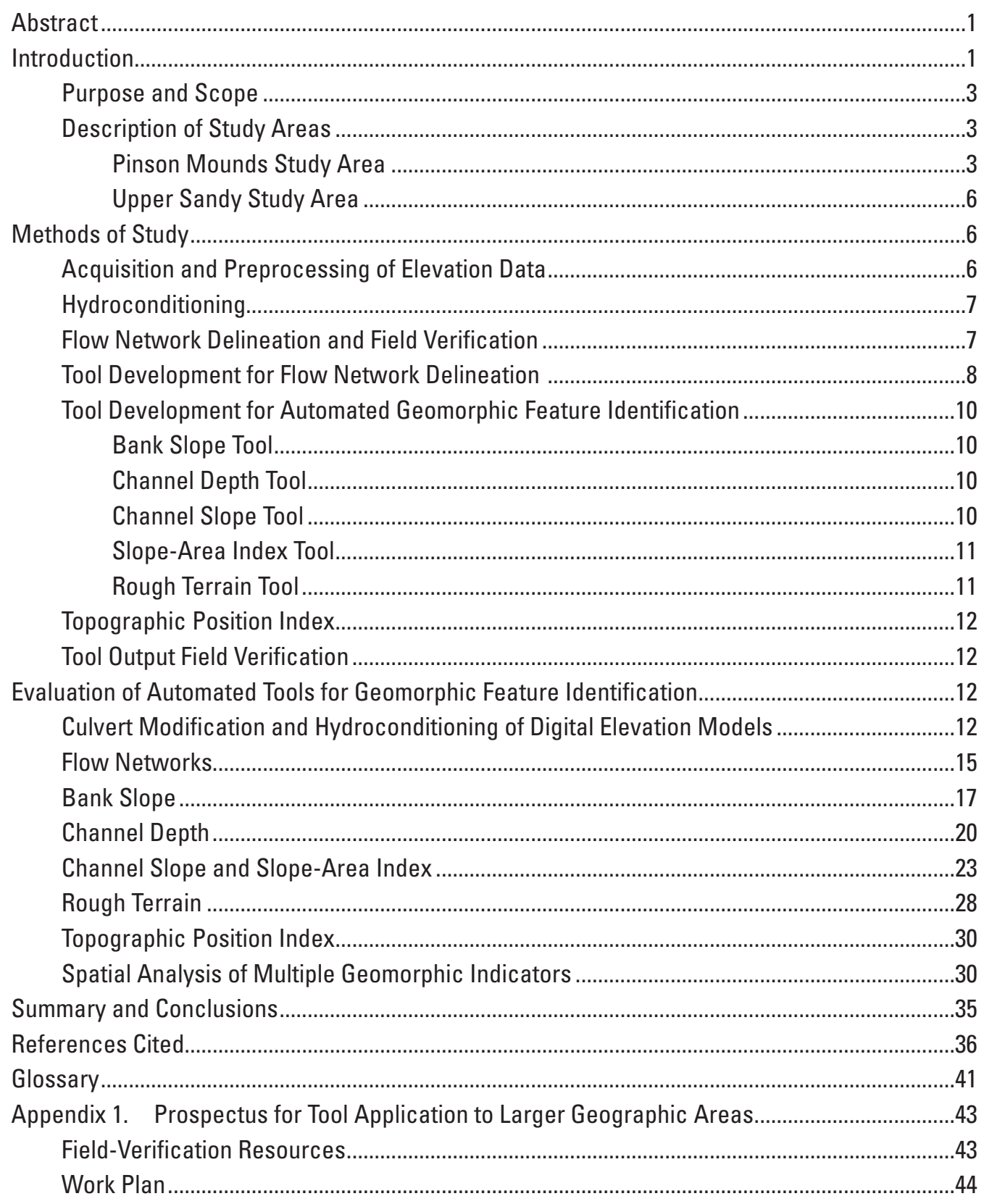




\section{Figures}

1. Map showing location of the Pinson Mounds study area, containing the Hudson Branch watershed and Pinson Mounds State Archaeological Area, Madison and Chester Counties, Tennessee

2. Map showing location of the Upper Sandy study area containing the headwater basin of Sandy Creek, Madison County, Tennessee...

3. Diagram showing suggested workflow for tools in the digital elevation model Geomorphology Toolbox

4. Maps showing locations in the Upper Sandy and Pinson Mounds study areas where tool output verification was performed using Global Positioning System-enabled photography and field-note dictation.

5. Maps showing examples of cut and fill records produced by the Optimized Pit Removal tool and flow-network modification based on incorporation of culvert locations into digital elevation models, Pinson Mounds study area.

6. Maps showing Flow Network tool outputs compared to the high-resolution flowline from the National Hydrography Dataset for the Upper Sandy and Pinson Mound study areas

7. Maps showing outputs from the Bank Slope tool within the Upper Sandy study area and along gully networks within the Pinson Mounds study area...

8. Composite showing an example of an actively eroding and overhanging bank in a stream-channel section identified by the Bank Slope tool as having a slope exceeding 50 percent but not exceeding 100 percent in the Pinson Mounds study area

9. Composite showing an area mapped with slope exceeding 100 percent that is vegetated and is probably stable, an area mapped with a slope exceeding 50 percent that shows signs of active erosion including exposed soil and overhanging roots, and output from the Bank Slope tool in the Pinson Mounds study area

10. Composite showing upstream view of a gully head upstream view of a narrow, steep-walled gully system upstream view of a channel connected to a floodplain in the base of a trench downstream view of the outlet of a gully system where flow enters the river floodplain, and calculated channel depth within gully networks using a 10 -foot search radius, Pinson Mounds study area.....

11. Composite showing a head cut 3 meters tall that was not detectable from high-resolution aerial imagery but associated with a flow-network zone of steep slope and high slope-area index, Upper Sandy study area.

12. Composite showing a, 0.5-meter-tall active head cut a root-stabilized head cut, and output from the Channel Slope and Slope-Area Index tools, Upper Sandy study area

13. Composite showing examples of errors produced by the Channel Slope tool and the Slope-Area Index tool, including a head cut not identified by the tools, a location in the flow-network with high slope-area index but no head cut, and tool outputs, Pinson Mounds study area

14. Composite showing an example of erosion at a culvert outlet that was not identified in Channel Slope tool or Slope-Area Index tool output, Upper Sandy study area 
15. Composite showing an example of a gully head eroding urban infrastructure, including an upstream view of the gully head a downstream view of the gully a close-up view of the eroded area undercutting asphalt, and boundaries of polygons generated by the Rough Terrain tool, Upper Sandy study area

16. Composite showing output polygons from the Rough Terrain tool superimposed on profile curvature derived from the digital elevation model, and on aerial orthoimagery of identical extent, Upper Sandy study area

17. Composite showing actively eroding head cuts in the main channel of a gully system, and a small tributary to the gully system, associated with feature clusters of outputs from multiple tools, Pinson Mounds study area

18. Composite showing A tributary gully, and an overhanging bank, associated with feature clusters of outputs from multiple tools, Upper Sandy study area

\section{Tables}

1. Numbers and lengths of digitized stormwater-infrastructure features ............................15

2. Summary of channel slope values produced by the Channel Slope tool...........................23

3. Summary of point values produced by the Slope-Area Index (SAI) tool ..........................24

\section{Conversion Factors}

\begin{tabular}{lcl}
\hline \multicolumn{1}{c}{ Multiply } & By & \multicolumn{1}{c}{ To obtain } \\
\hline & Length & \\
\hline centimeter $(\mathrm{cm})$ & 0.3937 & inch (in.) \\
meter $(\mathrm{m})$ & 3.281 & foot $(\mathrm{ft})$ \\
kilometer $(\mathrm{km})$ & 0.6214 & mile (mi) \\
\hline & Area & \\
\hline hectare $(\mathrm{ha})$ & 2.471 & acre \\
square meter $\left(\mathrm{m}^{2}\right)$ & 10.76 & square foot $\left(\mathrm{ft}^{2}\right)$ \\
square kilometer $\left(\mathrm{km}^{2}\right)$ & 0.3861 & square mile $\left(\mathrm{mi}^{2}\right)$ \\
\hline
\end{tabular}

Flow-network density

\begin{tabular}{lll}
\hline meter per hectare $(\mathrm{m} / \mathrm{ha})$ & 8.107 & foot per acre (ft/acre)
\end{tabular}

\section{Datums}

Vertical coordinate information is referenced to the North American Vertical Datum of 1988 (NAVD 88).

Horizontal coordinate information is referenced to North American Datum of 1983 (NAD 83) and World Geodetic System of 1984 (WGS 84).

Elevation, as used in this report, refers to distance above the vertical datum. 


\section{Abbreviations}

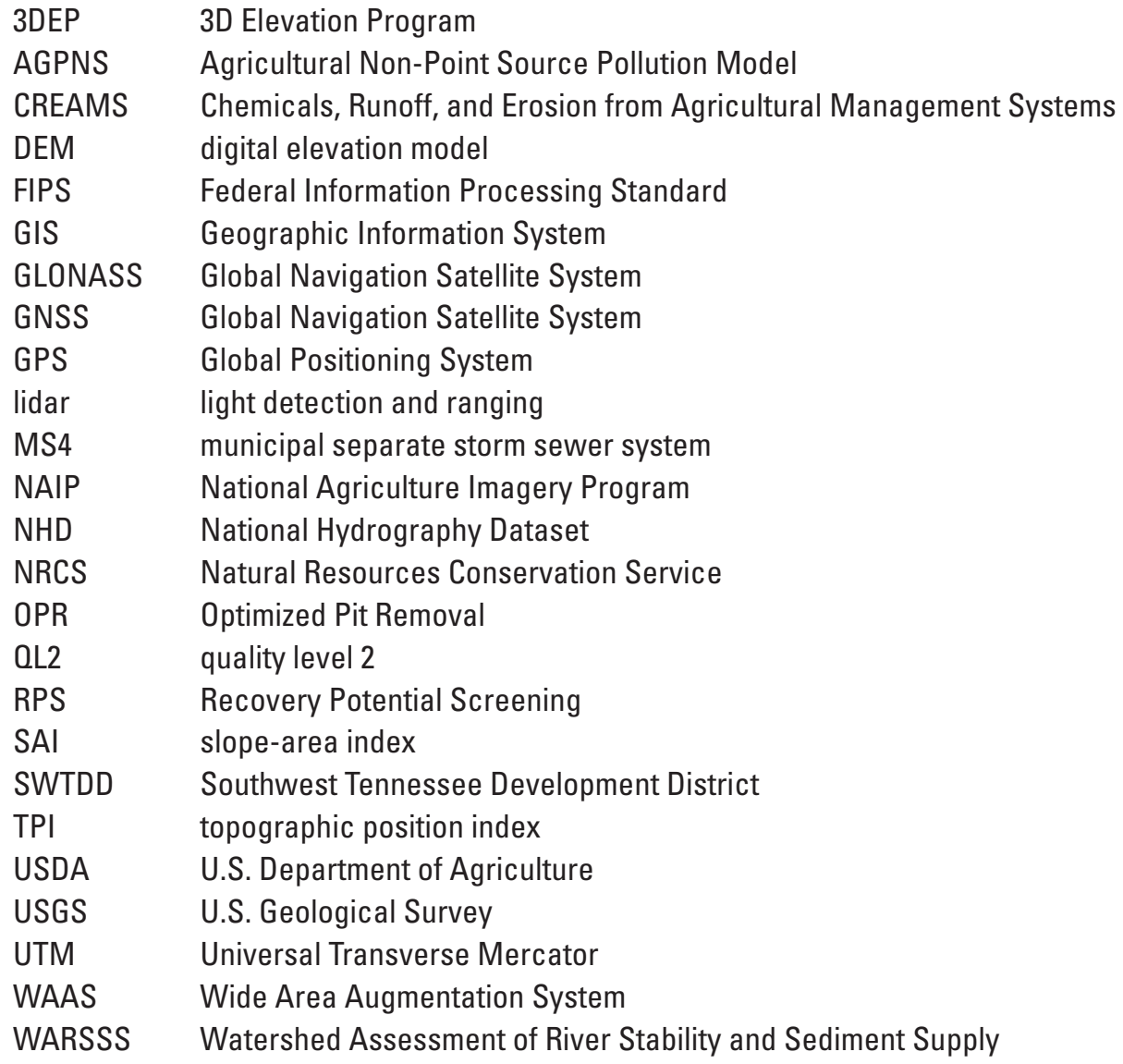




\title{
Automated Identification of Stream-Channel Geomorphic Features From High-Resolution Digital Elevation Models in West Tennessee Watersheds
}

\author{
By Jennifer M. Cartwright and Timothy H. Diehl
}

\begin{abstract}
High-resolution digital elevation models (DEMs) derived from light detection and ranging (lidar) enable investigations of stream-channel geomorphology with much greater precision than previously possible. The U.S. Geological Survey has developed the DEM Geomorphology Toolbox, containing seven tools to automate the identification of sites of geomorphic instability that may represent sediment sources and sinks in stream-channel networks. These tools can be used to modify input DEMs on the basis of known locations of stormwater infrastructure, derive flow networks at user-specified resolutions, and identify possible sites of geomorphic instability including steep banks, abrupt changes in channel slope, or areas of rough terrain. Field verification of tool outputs identified several tool limitations but also demonstrated their overall usefulness in highlighting likely sediment sources and sinks within channel networks. In particular, spatial clusters of outputs from multiple tools can be used to prioritize field efforts to assess and restore eroding stream reaches.
\end{abstract}

\section{Introduction}

Identifying sites of geomorphic instability ${ }^{1}$ within stream-channel networks is an important component of several watershed-management practices. For example, locating sites of erosion is vital for enhancing water quality and preserving aquatic habitat, because eroded sediment transported by streams is a leading cause of habitat impairment in lotic ecosystems (Ribaudo, 1986; Wood and Armitage, 1997; Henley and others, 2000) and in downstream estuaries (Thrush and others, 2004). Erosion has been linked to reduced biomass and diversity of benthic invertebrates in downstream reaches (Wantzen, 2006) and has negatively affected amphibian diversity and abundance (Smiley and others, 2009). Identifying erosional features

\footnotetext{
${ }^{1}$ Terms in bold are defined in the glossary.
}

within stream-channel networks is also important in efforts to mitigate potential threats to economically valuable resources, such as agricultural land and urban infrastructure. Erosional features near roads and other transportation infrastructure can undermine their structural stability (Cocker, 2007; Saksa and Minár, 2012). Gas pipelines, power lines, and other energy infrastructure features can be damaged over time by erosion (Cocker, 2007). In addition, erosional processes contribute to the degradation of agricultural land because of the loss of fertile topsoil (Vandekerckhove and others, 2001; Svoray and others, 2012).

Much of the eroded sediment in degraded landscapes comes from gully erosion, including ephemeral gullies in agricultural fields that are removable by cultivation, and permanent gullies that remain in place for years (Poesen and others, 2003). Gully erosion is a major cause of sedimentation in reservoirs (Valentin and others, 2005; Shellberg and Brooks, 2013) and on floodplains (Happ and others, 1975) downstream. Gully erosion generally enhances the connectivity or coupling of the sediment transport system from upstream slopes to downstream channels (Poesen and others, 2003; Aksoy and Kavvas, 2005), but in some places sediment from gullies overwhelms the transport capacity of streams and creates partial or complete barriers to sediment transport, including braided streams, alluvial fans, and valley plugs (Happ and others, 1940; Happ and others, 1975; Trimble, 2008). Depending on the location within the stream-channel network, the effects of gully erosion may be dominated either by channel deepening and widening or by channel filling (Booth and Henshaw, 2001).

The frequency, distribution, and severity of gully erosion are difficult to predict (Poesen, 2011; Poesen and others, 2011; Svoray and others, 2012). Existing models of erosion and sediment transport do not predict gully formation, but some can model gully erosion if data on gully characteristics are available, such as from the Agricultural Non-Point Source Pollution (AGNPS) model; Chemicals, Runoff, and Erosion from Agricultural Management Systems (CREAMS) model; and the SedNet model (Bull and Kirkby, 1997; Vandekerckhove and others, 1998; Merritt and others, 2003; Dougall and others, 2007; Eustace and others, 2009; Dabney and others, 2010; Taguas and others, 2012; Daggupati and 
others, 2013). Some watershed management tools can incorporate spatial information on gully characteristics relevant to watershed health and recovery (U.S. Environmental Protection Agency, 2012). In particular, the Watershed Assessment of River Stability and Sediment Supply (WARSSS) procedure can incorporate local observations of gully channel types and the recovery potential screening (RPS) method includes several metrics directly affected by gullies, particularly in the flow and channel dynamics subcategory (Norton and others, 2009; U.S. Environmental Protection Agency, 2012). Although documentation for each of these approaches acknowledges the importance of watershed-specific information about sediment sources and sinks, none of them include methods for the automated spatial identification of geomorphic features associated with erosion and sediment deposition.

Spatially precise information linking erosional features to downstream targets is important for achieving cost-effective reductions in suspended-sediment loads (Lu and others, 2004); however, acquiring this information is commonly time-consuming and thus expensive (Booth and Henshaw, 2001; Biron and others, 2013). Investigations of streamchannel geomorphology have historically relied on field survey techniques (Harrelson and others, 1994; Fitzpatrick and others, 1998). Traditional methods to quantify gully erosion and gully wall retreat have relied on time-intensive field methods such as erosion pin monitoring, measurement by theodolite, and repeated cross sections (Lawler, 1993; Vandekerckhove and others, 1998; Nyssen and others, 2006; Rustomji, 2006). Acquisition of field data is typically limited by resource constraints and land-access restrictions, requiring interpretation and inference for entire stream reaches based on limited numbers of surveyed cross sections and stream profiles. This is a major limitation of field-survey approaches, because individual cross sections provide little information about conditions upstream and downstream (Booth and Henshaw, 2001). In nonforested landscapes, mapping of erosional features such as gullies may be achievable using high-resolution aerial orthoimagery (Daggupati and others, 2013; Conoscenti and others, 2014). This approach is typically labor-intensive, because it relies on visual assessment either to analyze imagery or to verify results from automated methods. Moreover, the usefulness of aerial imagery in detecting erosional features is limited where canopy cover or thick ground vegetation obscures stream-channel geomorphology (Heine and others, 2004; James and others, 2007).

An alternative or complementary approach is to characterize stream-channel geomorphology in a geographic information systems (GIS) framework using hydrologic and elevation data. Some studies using this approach have relied on hydrologic networks and elevation data derived from topographic contour maps at scales of 1:10,000 or 1:24,000; for example, Desmet and others (1999) and Conoscenti and others (2014). The resolution of such datasets may not be sufficient to resolve small-scale erosional features, such as head cuts, especially if they are located in headwater streams (James and others, 2007). Moreover, the hydrography depicted in 1:24,000 U.S. Geological Survey (USGS) topographic maps has been shown to underestimate total stream length by more than 50 percent (Heine and others, 2004; James and others, 2007) and by as much as 80 percent if perennial, intermittent, and ephemeral streams are considered (Hansen, 2001). As a result, these data sources are of limited use in locating sites of geomorphic instability with small drainage areas. In addition, because such datasets are more than 30 years old, on average (Snyder, 2012), they are commonly outdated in urbanizing watersheds.

A promising, newly available data source derives from airborne light detection and ranging (lidar), an active remote-sensing technology that uses laser scanning to generate high-resolution digital elevation models (DEMs) over large areas. A variety of quality levels have been assigned to digital elevation data, with quality level 2 (QL2) representing 0.7-meter $(\mathrm{m})$ horizontal point spacing and 9.25-centimeter (cm) vertical accuracy (Snyder, 2012). On the basis of a cost-benefit analysis conducted as part of the National Enhanced Elevation Assessment (Dewberry, 2011), the USGS 3D Elevation Program (3DEP) set a target to acquire QL2 elevation data for the conterminous United States by the end of 2022, with an 8-year acquisition cycle thereafter (Carswell, 2013). In Tennessee, where this study was conducted, QL2 elevation data were available for less than one-third of the State's land area as of 2013 (Carswell, 2013). The State of Tennessee was awarded a grant by the USGS 3DEP in 2015 for planned acquisition of QL2 data for an additional 27 counties covering much of the eastern part of the state (Pederson, 2015). Thus, high-resolution DEM analysis will become increasingly feasible over the coming decades, even for remote or rural locations. In addition, time-series analysis of high-resolution DEMs becomes possible as repeated flights are conducted over time (Hessel and Van Asch, 2003; Martínez-Casasnovas, 2003; Shellberg and Brooks, 2013; Hogan and others, 2014).

Analysis of high-resolution DEMs can complement traditional approaches to the study of geomorphology by allowing spatially comprehensive assessment of topographic indicators, such as slope and curvature (Ferencevic and Ashmore, 2012; Biron and others, 2013; Daggupati and others, 2013), and rapid assessments of gully morphology (Perroy and others, 2010; Höfle and others, 2013). DEM-based analysis can be used to estimate indicators associated with fluvial erosion risk, such as bank slope and channel slope. Spatial identification of certain stream-channel geomorphic features may be useful to land managers and water-quality planners seeking to identify locations within stream-channel networks that are sources and sinks of sediment (Ferencevic and Ashmore, 2012). Because DEM-based analysis typically requires many steps and nested, iterative processes, efficiency can be improved by developing automated tools to process DEMs and produce spatial locations for geomorphic indicators 
of concern. Flexibility can be built into automated tools by allowing the user to adjust parameters of interest. An automated approach makes inherently subjective choices of geomorphic criteria consistent across the area of analysis, documents these choices, and enables comparison of results across multiple choices (user-adjusted parameter settings).

The USGS, in cooperation with the Southwest Tennessee Development District (SWTDD), conducted a 12-month pilot study to develop automated tools to identify possible locations of sediment contribution within stream-channel networks on the basis of QL2 DEMs. This pilot study was conducted in two contrasting study areas (one urban watershed, one rural) in Madison County, Tennessee. This pilot study was intended to provide (1) a preliminary set of tools for geomorphic feature identification to be used in local and regional planning efforts related to water quality, stream-channel restoration, infrastructure protection, and stormwater management, and (2) a prospectus describing the requirements for applying such tools to larger geographic areas in future work.

\section{Purpose and Scope}

The purpose of this report is to document the development of the DEM Geomorphology Toolbox ${ }^{2}$, which is a set of automated tools for the identification of geomorphic features in stream-channel networks that may be associated with erosion and sediment deposition. These geomorphic features are identified herein using high-resolution digital elevation models of watersheds in western Tennessee.

Field verification of tool outputs is documented for selected areas within the watersheds used for the pilot study based on accessibility, land ownership, and the spatial distribution of tool outputs. As such, the results presented herein represent preliminary findings from the pilot study and demonstrate a proof of concept that automated GIS tools for processing high-resolution DEMs can produce results indicative of geomorphic instability in stream-channel networks. The automated GIS tools produced in this study have not been verified in other watersheds or physiographic settings. To apply these tools beyond the two test watersheds, additional field verification and tool calibration would be required. A prospectus for tool application to larger geographic areas is included in appendix 1.

\section{Description of Study Areas}

Two test watersheds were selected as study areas and have similar slopes, soils, and subsoils. Both study areas are located within the Coastal Plain Physiographic Province

\footnotetext{
${ }^{2}$ The DEM Geomorphology Toolbox and associated metadata, including the tools described in this report, are available at http://dx.doi.org/10.5066/ F78C9TBQ.
}

of western Tennessee and cover a total of 15.3 square kilometers $\left(\mathrm{km}^{2}\right)$ of drainage area (figs. 1 and 2; Fenneman and Johnson, 1946; Hardeman and others, 1966; Brown and others, 1978). The two study areas have contrasting land-use histories and differing concentrations of urban infrastructure. Thus, these areas allowed tool development and calibration to be informed by differences in historical and current land use.

\section{Pinson Mounds Study Area}

The Pinson Mounds study area encompasses the Hudson Branch watershed and Pinson Mounds State Archaeological Area (fig. 1). Hudson Branch is a tributary of the South Fork Forked Deer River and has a total drainage area of about 945 hectares (ha), located southwest of the city of Jackson in Madison and Chester Counties, Tenn. The Hudson Branch watershed partially overlaps Pinson Mounds State Archaeological Area, a National Historic Landmark containing a complex of over a dozen prehistoric earthen mounds constructed during the Middle Woodland Period (circa 1-500 A.D.), making it one of the largest Middle Woodland ceremonial centers in eastern North America (Mainfort, 1988). Pinson Mounds State Archaeological Area contains approximately 500 ha of plateau-like upland, steep slopes, and floodplain immediately north of the South Fork Forked Deer River. This upland area ranges from approximately 130 to $150 \mathrm{~m}$ in elevation. The floodplain of the South Fork Forked Deer River is approximately $110 \mathrm{~m}$ in elevation and has minimal relief. The sloping bluffs separating the upland from the river floodplain are dissected by drainage networks characterized by permanent gully erosion. Although stormwater infrastructure features were mapped over the entire study area, these gullied areas were the focus of tool development and validation in this study area.

Soils within the Pinson Mounds study area are primarily silt loams. Depositional areas along the floodplain of the South Fork Forked Deer River are mapped as Waverly silt loam (Brown and others, 1978). Nearby, alluvial fans are mapped as Iuka and Enfield soils, but the alluvial fans in this study were too small to be mapped as independent units in the Madison County soil survey (Brown and others, 1978). Permanently gullied areas and steep slopes generally are Smithdale silt loam. The broad, gently sloping, formerly agricultural areas of Pinson Mounds State Archaeological Area are Lexington silt loam, with severe erosion in swales (Brown and others, 1978). The watershed is underlain by bedrock of the Midway Group (Hardeman and others, 1966).

The land-use history of the Pinson Mounds study area since the mid-19th century is characterized by agricultural use followed by succession to mixed hardwood forest.

Euro-American settlement in the area surrounding what is now the Pinson Mounds State Archaeological Area began in the 1820s and involved decades of intensive timber harvesting and the clearing of land for agriculture, predominantly corn and cotton under ridge cultivation (Mainfort and others, 2011). 


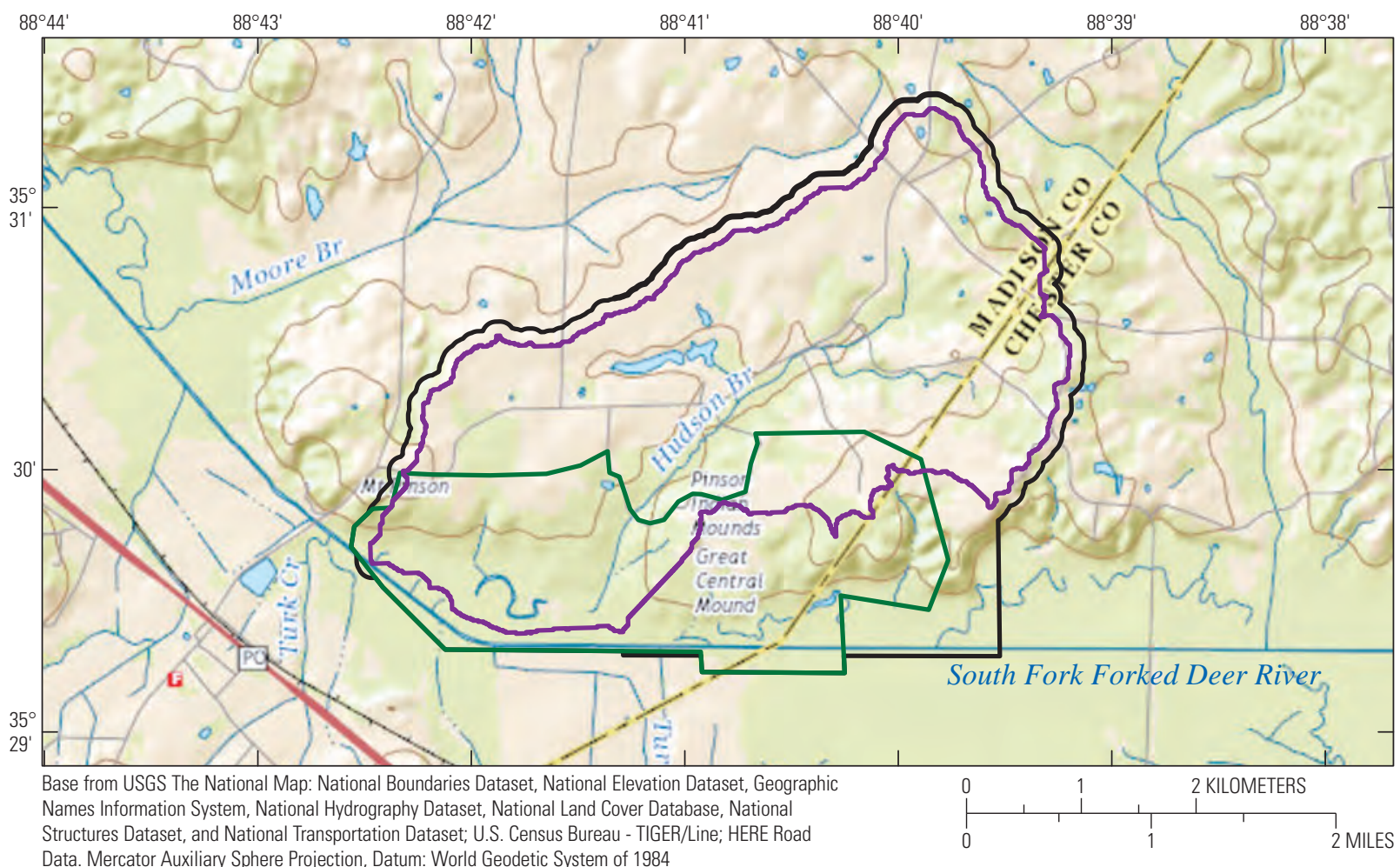

Data. Mercator Auxiliary Sphere Projection, Datum: World Geodetic System of 1984

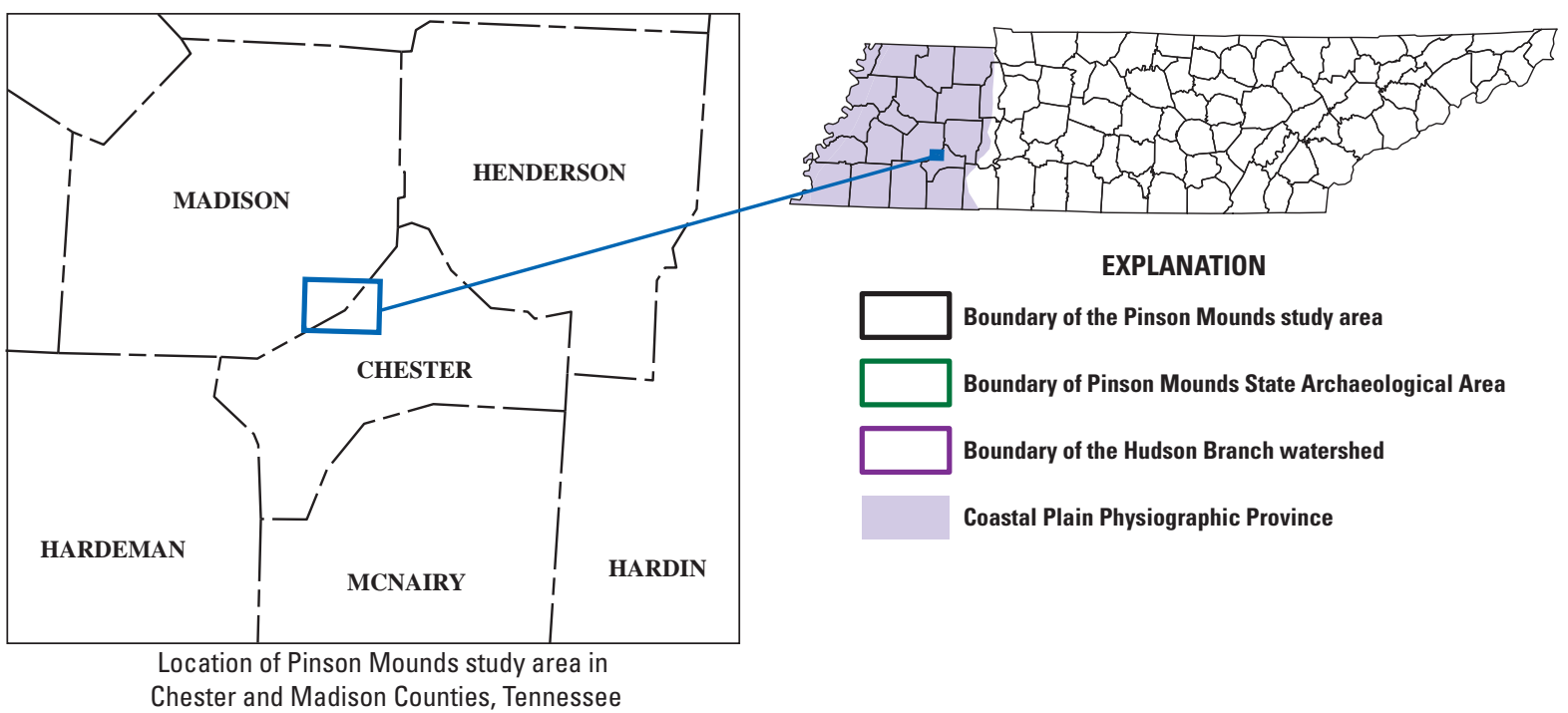

Figure 1. Location of the Pinson Mounds study area, containing the Hudson Branch watershed and Pinson Mounds State Archaeological Area, Madison and Chester Counties, Tennessee. 


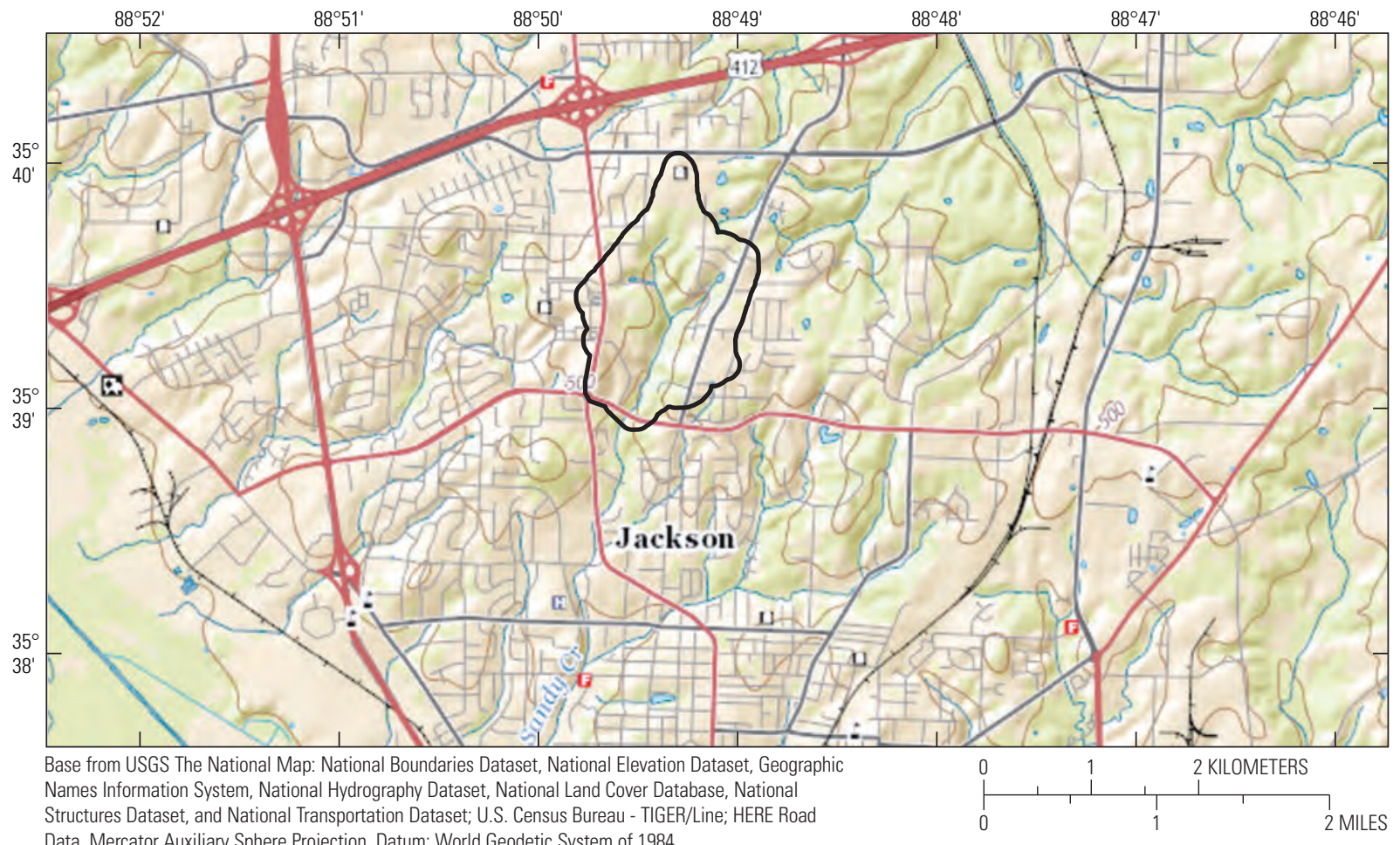

Data. Mercator Auxiliary Sphere Projection, Datum: World Geodetic System of 1984

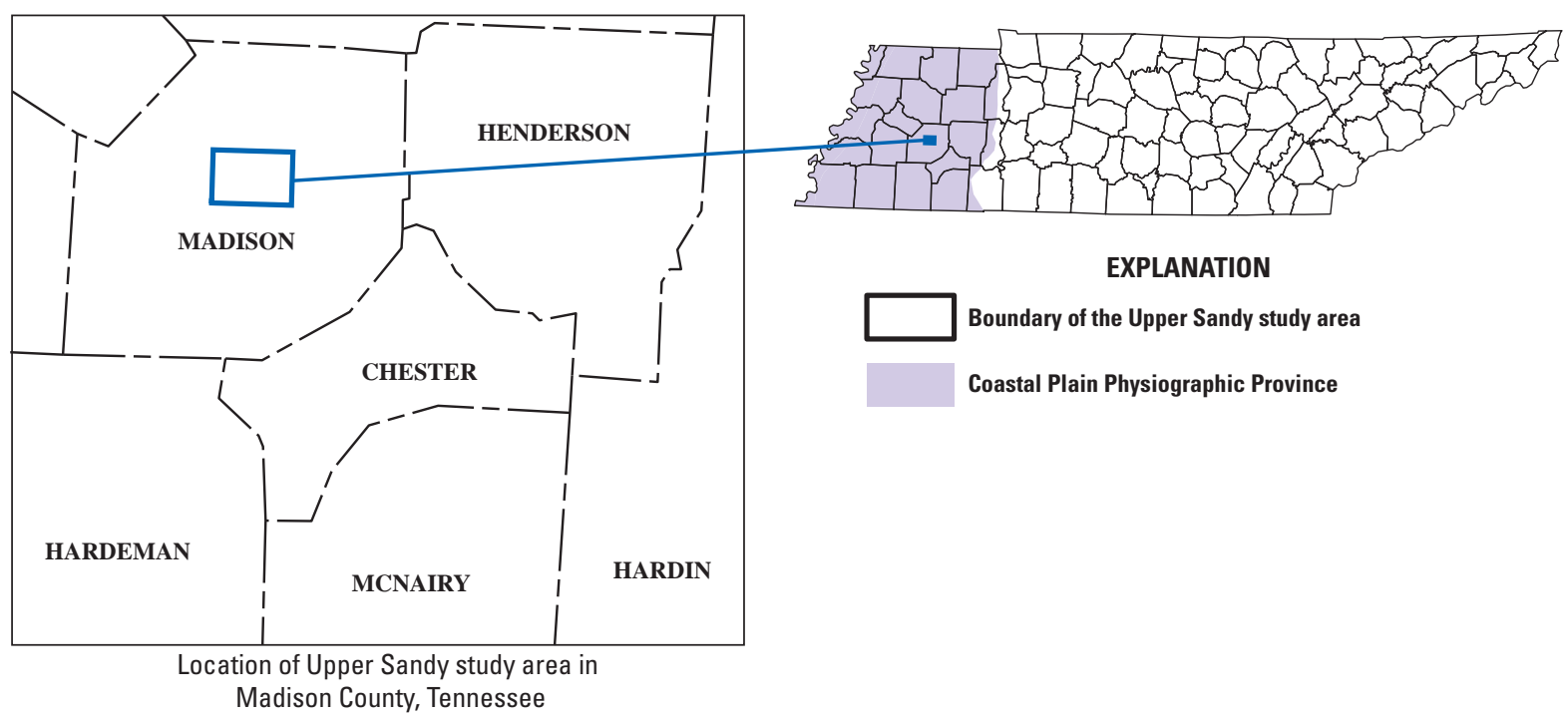

Figure 2. Location of the Upper Sandy study area containing the headwater basin of Sandy Creek, Madison County, Tennessee. 
Stream-Channel Geomorphic Features From High-Resolution Digital Elevation Models, West Tennessee

Row-cropping on the gently sloping uplands near the Pinson Mounds ceremonial sites continued until the mid-20th century, when the State of Tennessee purchased the land and, in 1974, designated the Pinson Mounds State Archaeological Area as a Tennessee State Park. After several decades of succession, the Pinson Mounds State Archaeological Area is now predominantly forested and has a network of roads and trails connecting visitor attractions such as campsites, picnic shelters, and archaeological areas. Upland forests are predominantly oak-hickory, forests on sloping bluffs between the upland and the river floodplain are mixed beech-oak, and the river floodplain is primarily cypress swamp (Broster and Schneider, 1977). Outside the boundary of the Pinson Mounds State Archaeological Area, the Hudson Branch watershed contains a mosaic of forest and agricultural land uses and a wider variety of soils (Brown and others, 1978).

\section{Upper Sandy Study Area}

The Upper Sandy study area is composed of the watershed for the headwaters of Sandy Creek, which is a tributary to the South Fork Forked Deer River. This study area encompasses approximately 180 ha in Madison County, Tenn., in the northern part of the city of Jackson (fig. 2). Elevation within the Upper Sandy study area ranges from approximately 130 to $165 \mathrm{~m}$.

Soils within the Upper Sandy study area are primarily silt loams and are subject to varying degrees of erosion. Soil along the downstream $300 \mathrm{~m}$ of Sandy Creek is mapped as Collins silt loam, formed in silty alluvium (Brown and others, 1978). Most of the stream, its tributaries, and nearby slopes are mapped as Lexington silt loam and have slopes ranging from 12 to 20 percent. Margins of the watershed and internal ridges are mapped as Memphis silt loam and are severely eroded in steeper areas. The Lexington and Memphis loams are similar, both developed in loess overlying sandy subsoil, but in the Memphis loam, this subsoil lies deeper than $150 \mathrm{~cm}$ where erosion is absent. Crops grown on the Memphis silt loam were the same as those grown on the Lexington silt loam, but with larger yields (Brown and others, 1978). Both soils belong to the Memphis-Lexington-Smithdale soil association, which is common in Madison County. The Upper Sandy study area is underlain by the Claiborne and Wilcox Formations (Hardeman and others, 1966), composed of nonmarine sands interspersed with clay lenses, which are exposed in the bases of some eroding streambanks (Roberts and Collins, 1926).

Land use within the Upper Sandy study area is a mixture of residential and commercial development and mixed hardwood forest. Development in this area began in the 1940s and 1950s along major roads along the eastern and western boundaries of the study area, then spread through the interior of the study area in the 1960s through 1990s (City of Jackson, 2015). Because of the greater urbanization in this watershed compared to the Pinson Mounds study area, the Upper Sandy study area contains a greater concentration of urban infrastructure features such as culverts, road ditches, and storm sewers.

Urbanization increases the importance of gully erosion, particularly relative to other sources of sediment, in two ways. First, a decrease in the area of bare and cultivated ground reduces surface erosion as a major sediment source (Poesen and others, 2003). Second, an increase in impervious area and drainage infrastructure generates greater runoff volume and faster delivery of water to stream-channel networks in frequent rainfall events, thereby promoting erosion in reaches downstream from culverts and armored ditches (Poesen and others, 2003; Cocker, 2007; Katz and others, 2014). Sandy Creek has characteristics that indicate geomorphic instability, including gully erosion in close proximity to urban infrastructure and degradation of water quality because of sediment loads. These issues have prompted the West Tennessee River Basin Authority to focus on restoring the stream (Blackwood, 2012).

\section{Methods of Study}

This study involved the development and refinement of automated tools to process DEMs derived from lidar. For the two study areas, DEMs based on lidar data produced in 2011-12 were acquired, preprocessed, and hydroconditioned. The hydroconditioned DEMs were used to derive preliminary flow networks that were then modified using data indicating the locations of stormwater infrastructure. The hydroconditioned DEMs and modified flow networks were used as data inputs to develop automated tools to identify geomorphic features that may be associated with streamchannel erosion, sediment transport, and sediment deposition. All geospatial preprocessing, modification, and analysis were performed using ArcGIS Desktop version 10.2 (Esri, Redlands, Calif.). Automated tools were developed using ArcGIS ModelBuilder (Esri, Redlands, Calif.).

\section{Acquisition and Preprocessing of Elevation Data}

Lidar-derived DEMs were obtained from the U.S. Department of Agriculture (USDA), Natural Resources Conservation Service (NRCS) (Dewberry, 2012). These DEMs represent "bare earth" elevation, meaning the elevation of the land surface (or water surface in the case of inundated areas) regardless of vegetation or canopy cover (Dewberry, 2012; Heideman, 2014). Lidar data were acquired between December 2010 and April 2011 for parts of 13 counties in western Tennessee at a nominal point spacing of $0.7 \mathrm{~m}$. The dataset is horizontally referenced to the North American Datum of 1983 (NAD 83), and has a horizontal accuracy of $1.04 \mathrm{~m}$ at the 95 -percent confidence level. The dataset is vertically referenced to the North American Vertical Datum of 1988 (NAVD 88), and has a vertical accuracy of $0.18 \mathrm{~m}$ 
at the 95-percent confidence level. The coordinate system is Universal Transverse Mercator (UTM) Zone 16. Horizontal and vertical units are in meters. Cell size is 1 square meter $\left(\mathrm{m}^{2}\right)$ and individual DEM tiles measure 1 by 1 kilometer $(\mathrm{km})$. Further details about this dataset are available in Dewberry (2012).

The following preprocessing steps were conducted to prepare the DEM tiles obtained from NRCS:

1. Individual DEM tiles for each study area were combined into a single DEM.

2. Study area polygons were produced by adding a $100-\mathrm{m}$ buffer around watershed polygons obtained from the USGS StreamStats Web application (Ladd and Law, 2007). For the Pinson Mounds study area, the buffered watershed polygon for Hudson Branch was merged with a polygon representing the extent of Pinson Mounds State Archaeological Area to produce the study area polygon.

3. DEMs were clipped to study area polygons.

4. Clipped DEMs were projected into the State Plane Coordinate System (NAD 83 State Plane Tennessee FIPS 4100 feet [ft]), with horizontal and vertical units in feet, while maintaining a $1-\mathrm{m}(0.304801-\mathrm{ft})$ cell size.

\section{Hydroconditioning}

The DEMs typically must be hydroconditioned prior to deriving hydrologic features such as flow networks (Jenson, 1991; Poppenga and others, 2010; Jackson, 2013). Hydroconditioning is a process by which elevation values are modified to produce coherent flow directions and flow accumulations. In particular, hydroconditioning requires the removal of internal topographic depressions (raster cells of low elevation completely surrounded by cells of higher elevations). Although some DEM depressions represent true features of the terrain, such as karst sinkholes, many others are artifacts of various processing operations that are needed to produce bare-earth DEMs, such as the removal of elevation values representing vegetation (Jenson, 1991; Poppenga and others, 2010; Dewberry, 2012; Heideman, 2014). In areas drained by stormwater infrastructure, areas upstream from infrastructure features, such as culverts and storm sewers, commonly appear in DEMs as depressions. Because the

\footnotetext{
${ }^{3} \mathrm{~A}$ common practice among lidar vendors, including the producer of the lidar-derived digital elevation models (DEMs) used in this study, is to remove elevation values corresponding to large bridges by interpolating groundsurface elevation values immediately surrounding bridges. Culverts and small bridges, especially bridges on secondary or tertiary roads, are not removed from DEMs (Dewberry, 2012).
}

routing of water through culverts and under small bridges is not represented in lidar-derived DEMs ${ }^{3}$, algorithms for deriving hydrologic features effectively treat roads and other infrastructure features underlain by culverts as "digital dams" and treat the areas upstream from culverts as depressions (Poppenga and others, 2010; Li and others, 2013; Chan and Crabtree, 2014).

A variety of techniques exist for modifying DEMs to remove topographic depressions in preparation for deriving hydrologic features - reviewed in Kenny and others (2008, table 2) -including DEM smoothing (O’Callaghan and Mark, 1984), outlet breaching (Martz and Garbrecht, 1999), and stream burning using existing vector representations of hydrologic networks (Callow and others, 2007). The filling of depressions (Jenson and Domingue, 1988) can be accomplished quickly in ArcGIS (Esri, Redlands, Calif.) using the Fill tool, which simply increases the elevation values within depression cells and thus allows water to be routed across the filled depression. With high-resolution lidar data, especially in areas of relatively flat terrain, this approach commonly results in large alterations that obscure meaningful topographic features upstream of any dam-like feature (Jackson, 2013). For this study, hydroconditioning was performed using the Optimized Pit Removal (OPR) tool (Jackson, 2013). This tool uses a combination of cuts (reductions in cell elevation) and fills (increases in cell elevations) to accomplish hydroconditioning while minimizing overall changes to the DEM. The OPR tool was set to minimize absolute elevation change.

\section{Flow Network Delineation and Field Verification}

Following hydroconditioning of the DEMs for each study area, preliminary flow networks were derived using standard flow-accumulation threshold methods as described by Jenson and Domingue (1988), Jenson (1991), and Poppenga and others (2010), using the ArcGIS Flow Direction and Flow Accumulation tools. Flow-accumulation thresholds of 1,000 and 5,000 cells (1,000 and 5,000 $\mathrm{m}^{2}$, or 0.1 and 0.5 ha, respectively) were applied to the output raster datasets from the Flow Accumulation tool. Thus, the preliminary flow networks included only those cells that drained at least 1,000 or $5,000 \mathrm{~m}^{2}$, respectively, with "no data" values assigned to all cells having flow accumulation values below the thresholds.

Because the functions of stormwater infrastructure, such as culverts and storm sewers, are not captured by lidar-derived DEMs (Poppenga and others, 2010; Li and others, 2013; Chan and Crabtree, 2014), the preliminary flow networks delineated in this study required field verification and, in many cases, flow-network correction. To prepare for field verification of flow networks, digital maps were prepared including the following base map layers: color orthoimagery from the National Agriculture Imagery Program (NAIP), hydroconditioned DEMs, DEM-derived profile curvature, 
cut and fill records from the OPR tool (which in many cases were useful for identifying likely culvert locations), and the preliminary flow networks at flow-accumulation thresholds of 1,000 and 5,000 cells. In addition, vector line files were included representing suspected culvert locations that were digitized in the office on the basis of visual examination of DEMs and derivative data layers. These data layers were loaded onto a Surface Pro 3 tablet (Microsoft, Redmond, Wash.) and accessed in the field using ArcGIS version 10.2 (Esri, Redlands, Calif.). Navigation was performed using a SkyPro XGPS160 Global Navigation Satellite System (GNSS) receiver (Dual Electronics, Heathrow, Fla.) with dual access to the U.S. Global Positioning System (GPS) and Russian Global Navigation Satellite System (GLONASS).

Flow-network verification was performed in the Pinson Mounds study area on December 9, 2014, and in the Upper Sandy study area on March 18 and April 10, 2015. Culvert locations were digitized in the field as vector line files viewed on top of the reference data layers. Culvert vector lines that had been digitized in the office were field-verified and edited as needed. Each culvert was automatically assigned a unique identification number, time stamp, length (in feet), and user identification based on the person who digitized each line. Culverts were also assigned a code to record whether they were digitized in the field or digitized in the office and then verified in the field. The southwestern part of the Upper Sandy study area contains relatively dense commercial development. In this area, the complexity of subterranean stormwater infrastructure rendered comprehensive digitization impossible. Surface stormwater infrastructure features were inspected, including culvert inlets, culvert outlets, levees along the edges of parking lots, and storm drains, to determine the most likely patterns of connectivity.

Following field inspection of preliminary flow networks, the culvert location files were used to modify the DEMs to improve flow-network accuracy. Culverts were incorporated into the DEMs as linear strips of elevation sufficiently low as to allow their inclusion on flow networks. The culvert locations were incorporated using the following steps:

1. Vector line files representing culvert locations were converted to raster.

2. Elevation values for all cells in each rasterized culvert were assigned the elevation of the lowest cell along that culvert. For this purpose, elevation values were taken from the raw (not hydroconditioned) DEMs.

\footnotetext{
${ }^{4}$ Stormwater-infrastructure features digitized in the two study areas were primarily culverts but also included a few longer and more complex subterranean features, such as conduits draining storm sewers. In this report, the term "culvert-modified" refers to digital elevation models that have been modified to incorporate culverts and other related types of stormwater infrastructure.
}

3. The raw (not hydroconditioned) DEMs were modified such that elevation values for culvert cells were equal to the output of step 2 above, whereas all nonculvert cells retained their original elevation values.

4. The culvert-modified DEMs (outputs from step 3 above) were hydroconditioned using the OPR tool.

By following the processing steps just described, raster datasets were produced representing hydroconditioned DEMs that incorporated stormwater-infrastructure locations. Using these culvert-modified ${ }^{4}$, hydroconditioned DEMs as inputs, modified flow networks were delineated using flow-accumulation thresholds of 1,000 and 5,000 cells, as described previously. These modified flow networks were checked against field notes (Cartwright and Diehl, 2016) and were compared to the high-resolution $(1: 24,000)$ flowlines from the National Hydrography Dataset (NHD; Simley and Carswell, 2009). In some areas of commercial development in the Upper Sandy watershed, deeper culverts crossed under roadways drained by shallower culverts, or under surface waterways carrying flow. These situations were only approximately represented by the culvert-modified DEM in which flow lines cannot cross each other; however, this complication did not appear to affect computed drainage area or flow routing to downstream sections of the flow network.

\section{Tool Development for Flow Network Delineation}

To make the processes of flow-network delineation quicker and more user-friendly, two ArcGIS tools were created as part of the DEM Geomorphology Toolbox: the Add Culverts tool and the Flow Network tool. The suggested workflow for all tools in the DEM Geomorphology Toolbox shown in figure 3 . All tools include detailed user instructions available in the tool dialogue windows.

The Add Culverts tool requires an input DEM and an input culvert file, which is an input vector line file representing the locations of stormwater infrastructure. The input DEM should be preprocessed to combine individual DEM tiles as needed and should be clipped to the watershed that includes the study area. From these inputs, the Add Culverts tool generates a culvert-modified DEM that includes modified elevation values along the locations of stormwater-infrastructure inputs. Notably, this modified DEM requires hydroconditioning (such as with the OPR tool) prior to use as an input for flow-network delineation.

The Flow Network tool requires, as input, a culvert-modified DEM (output of the Add Culverts tool) that has been subsequently hydroconditioned. The Flow Network tool allows the user to set a flow-accumulation threshold, which is the minimum number of cells that must drain into a raster cell for that cell to be included in the output flow network. Using the user-specified flow-accumulation threshold and the input DEM, the Flow Network tool produces three output files: 


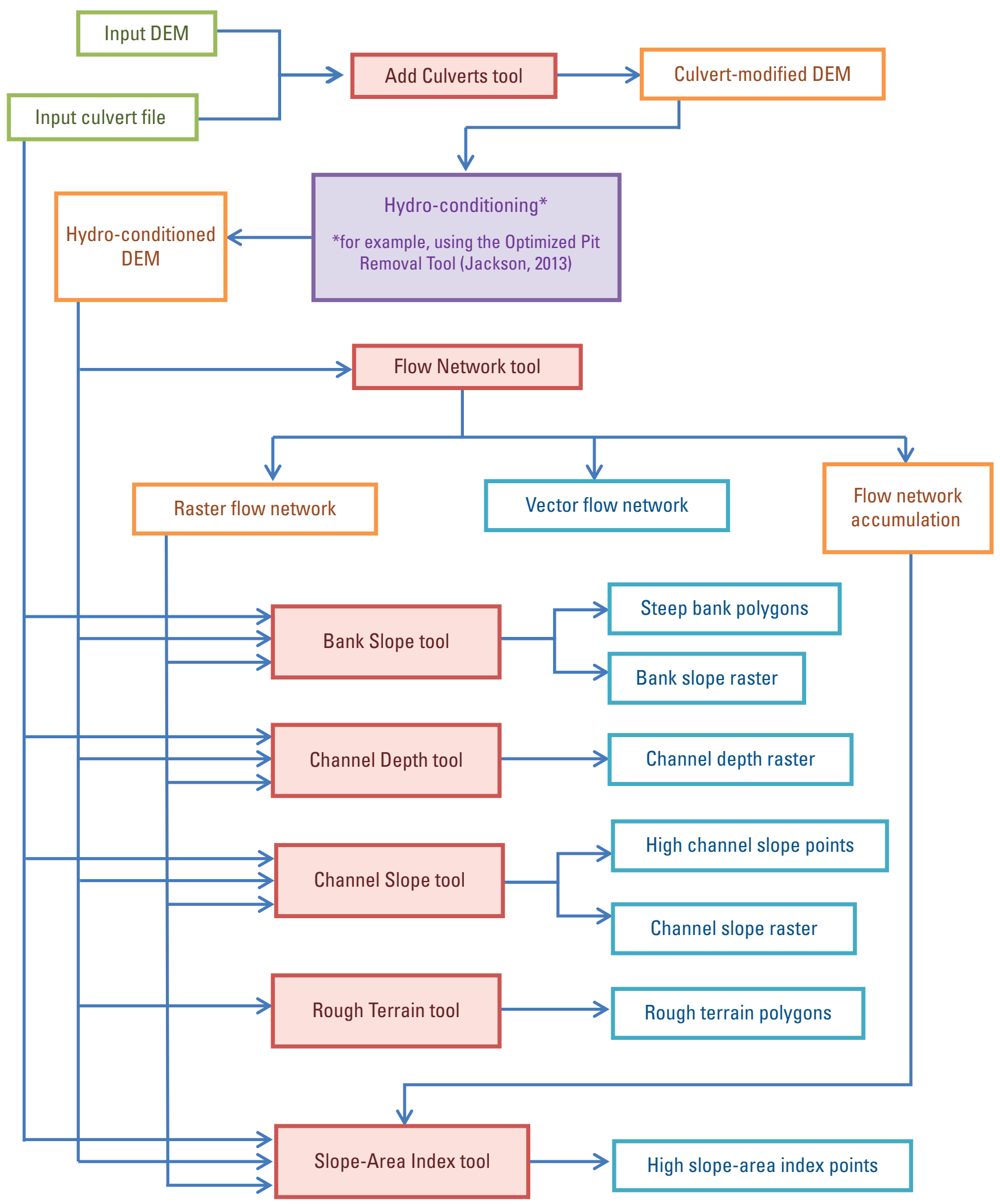

Figure 3. Suggested workflow for tools in the digital elevation model (DEM) Geomorphology Toolbox. Red boxes with pink shading represent the individual tools in the DEM Geomorphology Toolbox, green boxes represent data inputs, orange boxes represent intermediate data products, and blue boxes represent tool outputs. The purple box represents the hydroconditioning process, which is performed with tools available separately from the DEM Geomorphology Toolbox. 
1. A raster flow network file, with cells in the flow network having a value of 1 and cells not in the flow network having "no data" values.

2. A vector flow network file, which has a polyline for each flow-network segment, with segments separated by confluences.

3. A raster flow-network accumulation file, equivalent to the raster flow network except that values along the flow network contain flow accumulation values.

These output files are intended to serve as inputs for several automated tools within the DEM Geomorphology Toolbox that are used to identify geomorphic features, as described next.

\section{Tool Development for Automated Geomorphic Feature Identification}

Five tools were developed for the DEM Geormorphology Toolbox to automate the identification of certain geomorphic features from DEMs: the Bank Slope tool, the Channel Depth tool, the Channel Slope tool, the Slope-Area Index tool, and the Rough Terrain tool. These tools require, as input, the flow-network files and the culvert-modified, hydroconditioned DEMs produced using the Add Culverts and Flow Network tools. All tools include itemized user instructions available in the tool dialogue windows.

\section{Bank Slope Tool}

The Bank Slope tool requires, as input, a culvertmodified, hydroconditioned DEM, a raster flow network (output of the Flow Network tool), and an input vector line file representing stormwater-infrastructure locations. The Bank Slope tool allows the user to set a flow corridor width across which bank slope is calculated. User instructions for the Bank Slope tool explain that the units for this flow corridor width must be the same as the linear unit for the coordinate system for the input DEM. The user is also prompted to input a bank slope threshold, in percent rise, which is used to create vector polygons representing zones with bank slope exceeding the threshold.

The Bank Slope tool uses the input files and the user-specified flow-corridor width and bank-slope threshold to produce two output files:

1. A bank slope raster, representing the slope of cells within the user-specified flow corridor.

2. A steep banks polygon file, which is a vector polygon file representing areas of bank slope exceeding the user-specified bank-slope threshold.

The process of incorporating stormwater-infrastructure locations to modify DEMs using the Add Culverts tool produces artifacts resembling steep bank slopes. These artifacts are included in the output bank slope raster produced by the Bank Slope tool; however, this tool uses the input culvert location file to remove polygons within $30 \mathrm{ft}(9.14 \mathrm{~m})$ of culverts from the output steep banks polygon file.

\section{Channel Depth Tool}

The Channel Depth tool requires, as input, a culvert-modified, hydroconditioned DEM, a raster flow network (output of the Flow Network tool), and an input vector line file representing stormwater-infrastructure locations. The user can set a search radius within the Channel Depth tool dialogue window to identify the maximum elevation value in the input DEM. Using the input files and a user-specified search radius, the Channel Depth tool produces a channel depth raster corresponding to the input flow network. For each cell in the channel depth raster, the cell value represents the difference between that cell's elevation and the maximum elevation within the user-specified search radius from that cell. Units of the channel depth raster are the same as the units of the input DEM.

The process of incorporating stormwater infrastructure locations to modify DEMs using the Add Culverts tool produces artifacts resembling deep channels. The Channel Depth tool uses the input culvert location file to remove from the output raster the cells along the flow network corresponding to culvert locations. Instead of depth values, these cells have "no data" values.

\section{Channel Slope Tool}

The Channel Slope tool requires, as input, a culvert-modified, hydroconditioned DEM, a raster flow network (output from the Flow Network tool), and an input vector line file representing stormwater-infrastructure locations. Using these inputs, the tool calculates the slope along the flow network and produces the following output files:

1. A channel-slope raster containing slope values along the flow network, in percent rise.

2. A vector point file representing locations of channel slope greater than 2 percent.

The process of incorporating stormwater-infrastructure locations to modify DEMs using the Add Culverts tool produces artifacts resembling steep channel slopes at culvert entrances. These artifacts are included in the output channel slope raster produced by the Channel Slope tool; however, the Channel Slope tool uses the input culvert location file to remove points within $10 \mathrm{ft}$ (3.05 m) of culverts from the output vector point file. 


\section{Slope-Area Index Tool}

The Slope-Area Index tool requires as input a culvert-modified, hydroconditioned DEM, a raster flow network and a raster flow-network accumulation file (both are outputs of the Flow Network tool). Using these inputs, the tool calculates the slope along the flow network, equivalent to the output from the Channel Slope tool. The Slope-Area Index tool then calculates the slope-area index (SAI) (Vandaele and others, 1996; Daggupati and others, 2013) for each cell on the flow network as follows:

$$
\mathrm{SAI}=\mathrm{S} \times \mathrm{A}^{\mathrm{b}}
$$

where

SAI is the slope-area index,
S is the channel slope,
A is the drainage area (the number of cells
draining into the target cell), and
b is a user-specified exponent.

Previous investigations have demonstrated that ephemeral gully erosion is typically best predicted by SAl using an exponent value of $b=0.4$, but area exponents found in a variety of gully-erosion settings range from approximately 0.1 to 0.6 (Montgomery and Foufoula-Georgiou, 1993; Vandaele and others, 1996; Vandekerckhove and others, 1998; Desmet and others, 1999; Daggupati and others, 2013). Therefore, the default value for the exponent parameter in the Slope-Area Index tool dialogue window is set to 0.4 , but this parameter can be adjusted by the user. The tool also includes as a user-specified parameter an SAI threshold above which to identify high-SAI point locations.

The tool uses the inputs and user-specified parameter settings to produce as output a point feature class representing locations along the input flow network where SAI equals or exceeds the SAI threshold. The process of incorporating stormwater-infrastructure locations to modify DEMs using the Add Culverts tool produces artifacts resembling steep channel slopes at culvert entrances. Because channel slope is a variable used to calculate SAI, culvert locations can produce artifacts resembling high SAI values. Therefore, the Slope-Area Index tool uses the input culvert location file to remove points within $10 \mathrm{ft}(3.05 \mathrm{~m})$ of culverts from the output vector point file.

\section{Rough Terrain Tool}

The Rough Terrain tool identifies areas within the input DEM that represent concentrations of high profile curvature (high convexity and high concavity) connected by steep slopes. Profile curvature is defined as curvature in the direction of maximum slope and thus represents the first derivative of slope. This tool was designed and calibrated so as to identify areas of known gully erosion in the two study areas. These areas have been produced by channel incision and can be identified from DEMs, because their bank tops produce high levels of upward convexity, their thalwegs produce high levels of upward concavity, and these two zones are typically connected spatially by steep banks.

The Rough Terrain tool can be run on any high-resolution DEM. Unlike the other tools in the DEM Geomorphology Toolbox described herein, for which analysis is confined to the immediate vicinity of flow networks based on user-specified distances, the Rough Terrain tool processes data across the entire landscape. As a result, the input DEM does not necessarily have to be hydroconditioned (meaning that the tool will run successfully on an input DEM with internal depressions). Users may wish to use raw (not culvert-modified or hydroconditioned) DEMs as inputs to avoid generating artifacts of rough terrain produced by the processes of incorporating stormwater infrastructure and removing internal depressions. Because the Rough Terrain tool performs landscape-level analysis rather than channel-based analysis, an input flow network is not required.

The Rough Terrain tool uses an input DEM to produce an output vector polygon representing zones of rough terrain (high profile curvature and steep slope) according to three user-specified threshold parameters: the slope-threshold parameter, the curvature-threshold parameter, and the polygon-area-threshold parameter. The slope-threshold parameter is the slope value, in percent rise, above which zones within the DEM will be eligible for inclusion in the output polygon file. The default value is 50 , indicating that zones with a slope that exceeds a 50-percent rise will be eligible for inclusion. The curvature-threshold parameter is the absolute value of profile curvature above which zones within the DEM will be eligible for inclusion in the output polygon file. Profile curvature values are positive for DEM zones having upward concavity (such as stream-channel thalwegs) and negative for zones having upward convexity (such as ridges and channel bank tops). The default value for the curvature threshold parameter is set at 5.0, indicating that zones having upward concavity values greater than or equal to 5.0 will be eligible for inclusion, as will zones having upward convexity less than or equal to -5.0. Using these two parameter settings, the tool creates areas of steep slope and areas of high profile curvature and then spatially merges these zones. The merged zones, composed of steep slope and (or) high profile curvature, are then compared to the user-defined polygon-area-threshold parameter to produce the final output polygon file. The polygon area threshold is the minimum area, in number of raster cells of input DEM, of the contiguous area of merged zones required for those zones to be included as an output polygon. The default value is set at 300 , indicating that merged zones will be included as output rough terrain polygons if and only if their contiguous area is equal to or greater than 300 raster cells. 


\section{Topographic Position Index}

Raster files of topographic position index (TPI) were created at multiple neighborhood sizes (Weiss, 2001) for both study areas. Positive TPI values represent cells, such as along ridgetops, with higher elevation values than the average of the specified neighborhood. Negative TPI values represent cells, such as along stream-channel thalwegs, with lower elevation values than the neighborhood average. TPI values near zero represent cells in areas of relatively constant slope, including flat sloped areas and flat level areas. The upstream ends of depositional areas within stream-channel networks, such as the heads of alluvial fans, generally represent topographic contexts where confined stream channels rapidly transition downstream into areas of generally open topography. Therefore, rapid increases in TPI values along flow networks were hypothesized to be useful indicators of depositional features.

Using TPI calculated with a three-cell-radius circular neighborhood, point locations were derived as follows to represent relatively abrupt changes in TPI along flow networks:

1. TPI values were averaged along flow networks by applying a focal mean with a 20-cell-radius circular neighborhood.

2. Averaged TPI values from step 1 were used to assign binary values along the flow network equal to 0 if averaged TPI exceeded -0.5 or equal to 1 , if not.

3. Slope was calculated on binary values from step 2 .

4. Binary values from step 2 were multiplied by slope values from step 3.

5. Points were created representing cells with product values from step 4 not equal to zero.

\section{Tool Output Field Verification}

Tool outputs from the Bank Slope, Channel Depth, Channel Slope, Slope-Area Index, and Rough Terrain tools were field-verified in selected parts of both study areas (fig. 4). In particular, field locations where tool outputs suggested possible geomorphic instability—such as steep bank polygons, high-channel-depth locations, high-SAI points, and rough terrain polygons - were photographed and described in field notes (Cartwright and Diehl, 2016). Commission errors were indicated where geomorphic instability was suggested by tool outputs but not observed in the field. Conversely, omission errors were indicated where geomorphic instability was observed in the field but not represented by tool outputs. Field locations representing both types of errors were photographed and described.
Tool output verification was performed in the Pinson Mounds study area on August 13 and 14, 2015, and in the Upper Sandy study area on September 12 and 14, 2015. In both study areas, field navigation was performed using printed maps of tool outputs and an eTrex H handheld GPS (Garmin, Olathe, Kan.). Field photography was performed using a Pentax Optio WG-2 GPS camera (Ricoh Ltd., Tokyo, Japan) with enabled Wide Area Augmentation System (WAAS) GPS to produce GPS-embedded photographs. At each field location where photographs were taken, field notes were dictated as audio (.WAV) files using the camera's microphone and were later transcribed to text (.RTF) files using Dragon NaturallySpeaking premium edition, version 12.50.000.142 (Nuance, Burlington, Mass.). Field notes were linked to photographs and to GPS locations using a common system of unique identification numbers.

\section{Evaluation of Automated Tools for Geomorphic Feature Identification}

Application of the tools in the DEM Geomorphology Toolbox to the DEMs from the Pinson Mounds and Upper Sandy study areas successfully produced flow networks and other tool outputs. Field-verification of tool outputs indicated that, although not all features identified by the tools corresponded to field indicators of geomorphic instability, the tools generally produced spatial data that were useful in locating and identifying areas of erosion and deposition within stream-channel networks.

\section{Culvert Modification and Hydroconditioning of Digital Elevation Models}

Application of the OPR tool (Jackson, 2013) to the DEMs for both study areas yielded hydroconditioning sufficient for delineating flow networks. By differencing the input DEM from the output DEM obtained from the OPR tool, a record of cuts and fills was produced. Examination of spatial patterns in cuts and fills provided information about the nature of alterations performed by the OPR tool and, in some cases, provided clues about the geomorphic context of those alterations (fig. 5A). For example, isolated single cells that were filled by the OPR tool may represent DEM artifacts (fig. 5A, blue arrow). In some cases, culverts produced "depressions" in the input DEM that were removed by the OPR tool. These features are identifiable as linear zones of cut cells downstream from multicell filled areas that are immediately upstream of culverts (fig. 5A, pink arrows).

Field inspections of preliminary flow networks identified multiple sites where preliminary flow networks were inaccurate owing to the presence of stormwater infrastructure, primarily culverts, but also gutters, ditches, and storm sewers. 

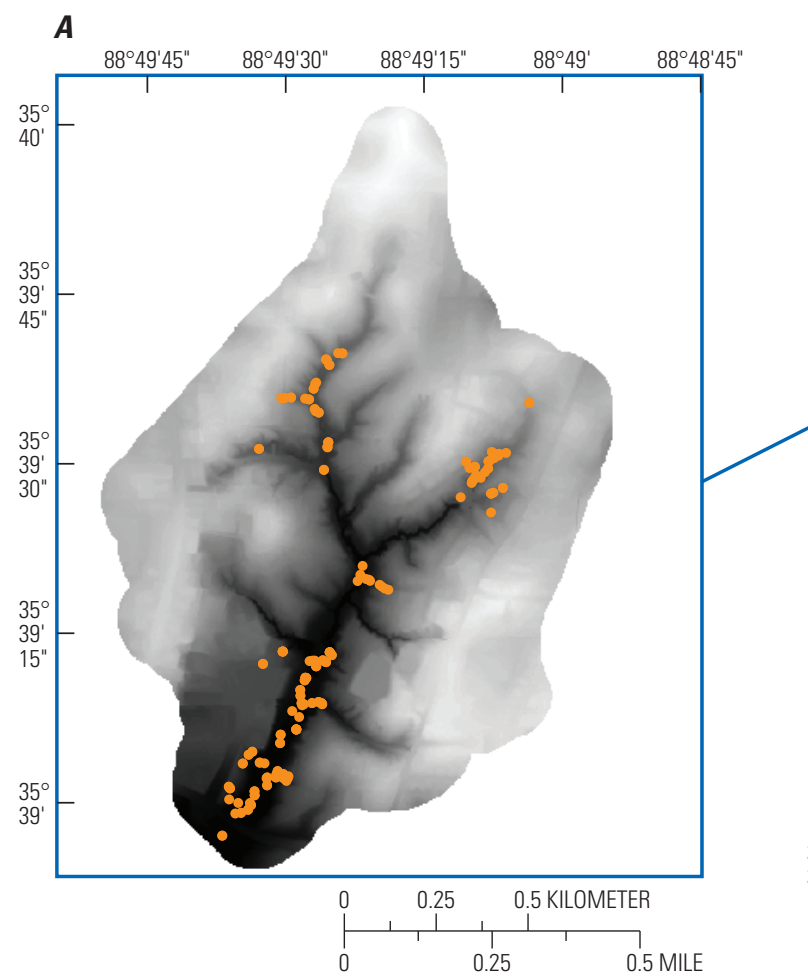

B
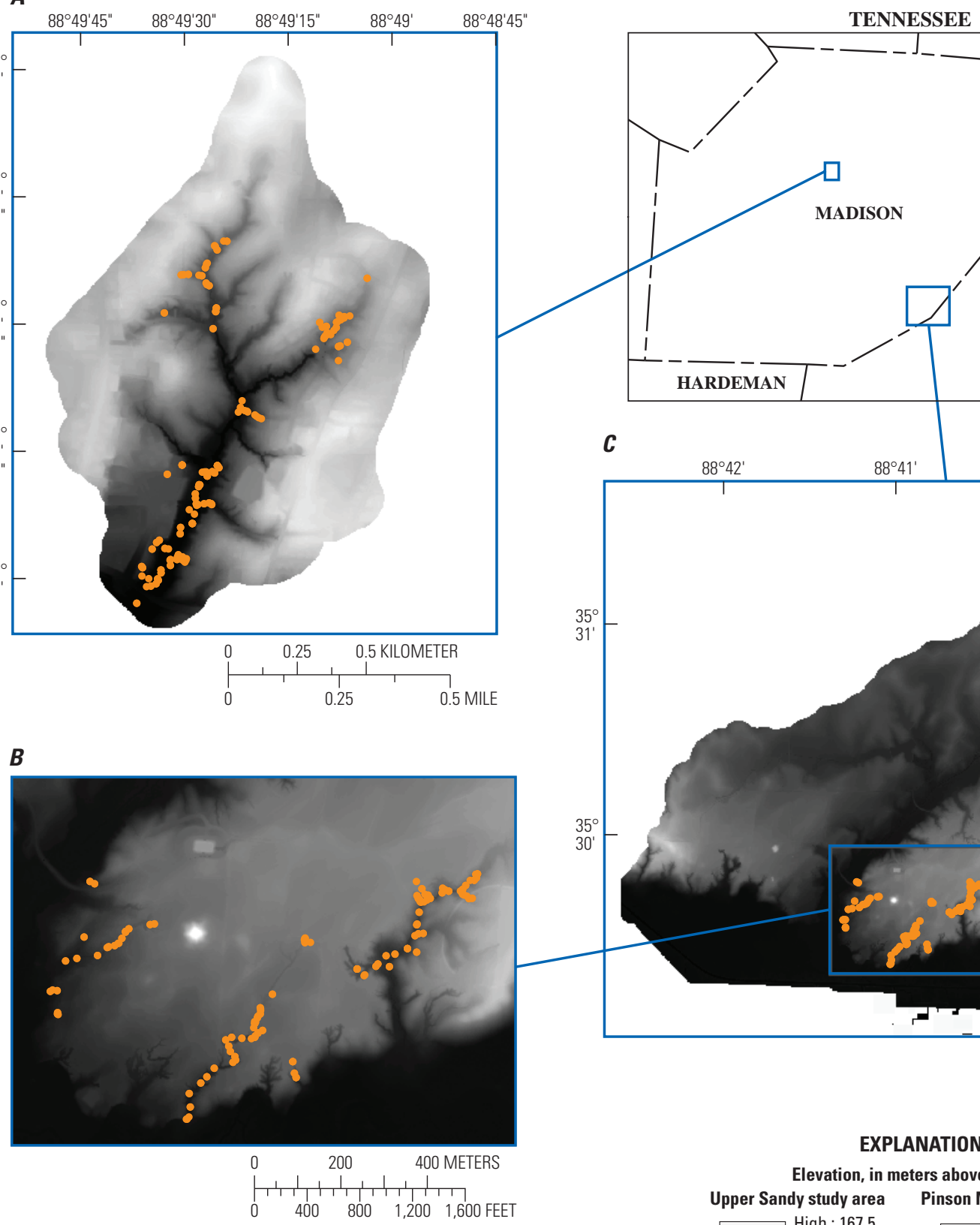

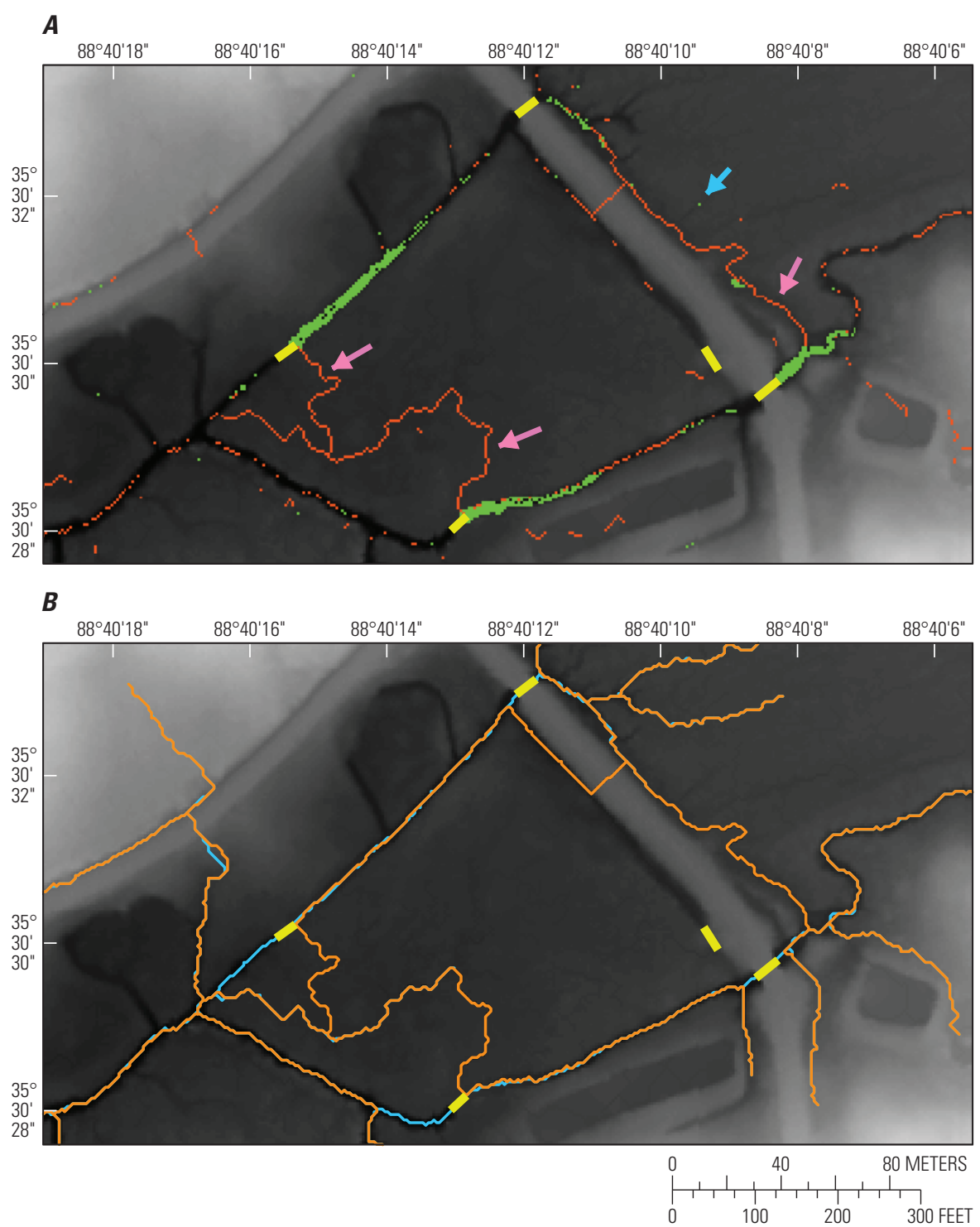

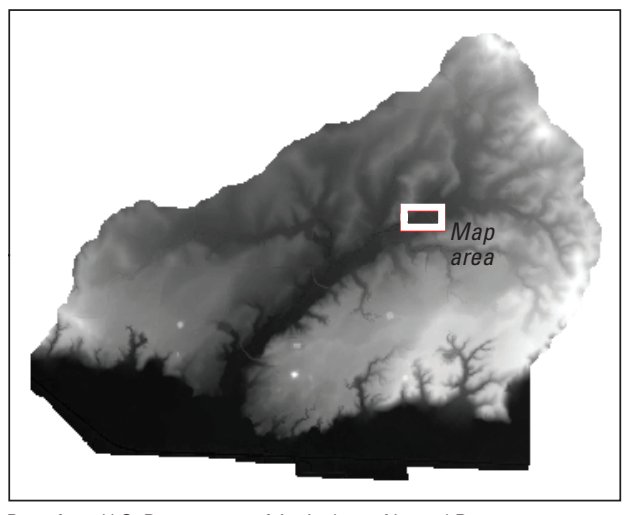

Base from U.S. Department of Agriculture, Natural Resources Conservation Service, 1-meter-cell-size digital elevation model, 2011. Lambert Conformal Conic Projection, Horizontal datum: North American Datum of 1983 (NAD 83), Vertical datum: North American Vertical Datum of 1988 (NAVD 88).

\section{EXPLANATION}

Elevation, in meters above NAVD88

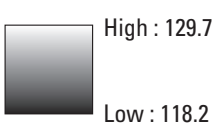

Cells cut by the OPR tool

Cells filled by the OPR tool

Culverts

Flow network before culvert modification

Flow network after culvert modification

$<$ Isolated single-fill cell

$<$ OPR-artifact channel

Figure 5. Examples of $A$, cut and fill records produced by the Optimized Pit Removal (OPR) tool and, $B$, flownetwork modification based on incorporation of culvert locations into digital elevation models, Pinson Mounds study area. Both flow networks in $B$ were delineated using a flow-accumulation threshold of 5,000 cells. 
These findings are similar to those of previous studies that found substantial errors in mapped stream networks resulting from the presence of roads and other drainage obstructions acting as "digital dams" in DEMs (Poppenga and others, 2009; Li and others, 2013; Chan and Crabtree, 2014). A total of 128 stormwater-infrastructure features were digitized in the two study areas (table 1). In the Upper Sandy study area, the longest lines digitized (representing features longer than $60 \mathrm{~m}$ ) were clustered primarily in the southwestern part of the study area, which is characterized by dense commercial development. The process of mapping these long underground conveyances was disproportionately slower and more difficult than mapping the other stormwater-infrastructure features documented in this study.

By comparing flow networks delineated before and after use of the Add Culverts tool (example in fig. 5B), it was possible to identify areas where the incorporation of stormwater infrastructure (culvert modification of DEMs) caused substantial changes to the flow network and areas where it did not. In some cases, the OPR tool alone was able to "cut" flow paths into the unmodified DEM, allowing preliminary flow networks (before culvert modification) to approximate the pattern of the culvert-modified flow networks. In other cases, the culvert-modified flow network differed greatly from the preliminary flow network. These results suggest that DEM modifications based on data representing stormwater-infrastructure locations can improve the accuracy of DEM-derived flow networks (Poppenga and others, 2009; Li and others, 2013; Chan and Crabtree, 2014).

The primary limitation of the Add Culverts tool is the requirement of spatially precise data concerning the locations of stormwater infrastructure. For small geographic areas where the density of stormwater infrastructure is low and infrastructure features are readily apparent by field inspection, field data collection may be practical. For example, rural areas where stormwater infrastructure is generally limited to short culverts under roads and driveways may be suitable for field-data collection. With an increase in geographic scale or infrastructure density and complexity, the time and resources required to digitize stormwater infrastructure locations in the field also increase and may become prohibitive. For large geographic areas or areas having extensive stormwater infrastructure, culvert modifications to DEMs could be achieved using culvert location data obtained from partnering institutions, such as municipalities administering a municipal separate storm sewer system (MS4; Cubanski, 2013; Li and others, 2013; Venner, 2014).

\section{Flow Networks}

Culvert-modified flow networks delineated using the Flow Network tool, with flow-accumulation thresholds of 5,000 and 1,000 cells, showed general alignment to the highresolution $(1: 24,000)$ flowlines from the NHD (Simley and Carswell, 2009). The tool outputs, however, continued farther upstream to include more headwater reaches and included many small tributaries not present in the NHD flowline (fig. 6). The flow networks produced by the Flow Network tool were generally more sinuous and appeared less smoothed than the NHD flowline (fig. 6B). The NHD flowline was not present within the gullied areas in Pinson Mounds State Archaeological Area (fig. 6C), indicating the value of the Flow Network tool in this study area for delineating flow networks having relatively small drainage areas.

In both study areas, flow-network delineation using a flow-accumulation threshold of 1,000 cells produced considerably denser drainage networks than delineation using a threshold of 5,000 cells. In the Pinson Mounds study area, the 1,000-cell threshold produced a flow network having a density of 296 meters per hectare (m/ha), which was more than twice as dense as the flow network produced using a 5,000-cell threshold (136 m/ha). Similarly, in the Upper Sandy study area, flow-network density was 239 and $87 \mathrm{~m} / \mathrm{ha}$ for the flow networks produced with 1,000-cell and 5,000-cell thresholds, respectively.

Table 1. Numbers and lengths of digitized stormwater-infrastructure features.

[NA, not applicable]

\begin{tabular}{l|ccc|cc}
\hline \multirow{2}{*}{$\begin{array}{c}\text { Study } \\
\text { area }\end{array}$} & \multicolumn{3}{c|}{$\begin{array}{c}\text { Number of } \\
\text { stormwater features }\end{array}$} & $\begin{array}{c}\text { Length of digitized lines } \\
\text { representing stormwater infrastruc- } \\
\text { ture features }\end{array}$ \\
\cline { 2 - 6 } & $\begin{array}{c}\text { Digitized } \\
\text { in field }\end{array}$ & $\begin{array}{c}\text { Digitized in office } \\
\text { and verified by } \\
\text { field inspection }\end{array}$ & Total & $\begin{array}{c}\text { Minimum } \\
\text { (meters) }\end{array}$ & $\begin{array}{c}\text { Maximum } \\
\text { (meters) }\end{array}$ \\
\hline $\begin{array}{l}\text { Upper Sandy } \\
\text { Pinson Mounds }\end{array}$ & 42 & 16 & 58 & 1.5 & 530 \\
Total & 32 & 38 & 70 & 7.0 & 105 \\
\hline
\end{tabular}




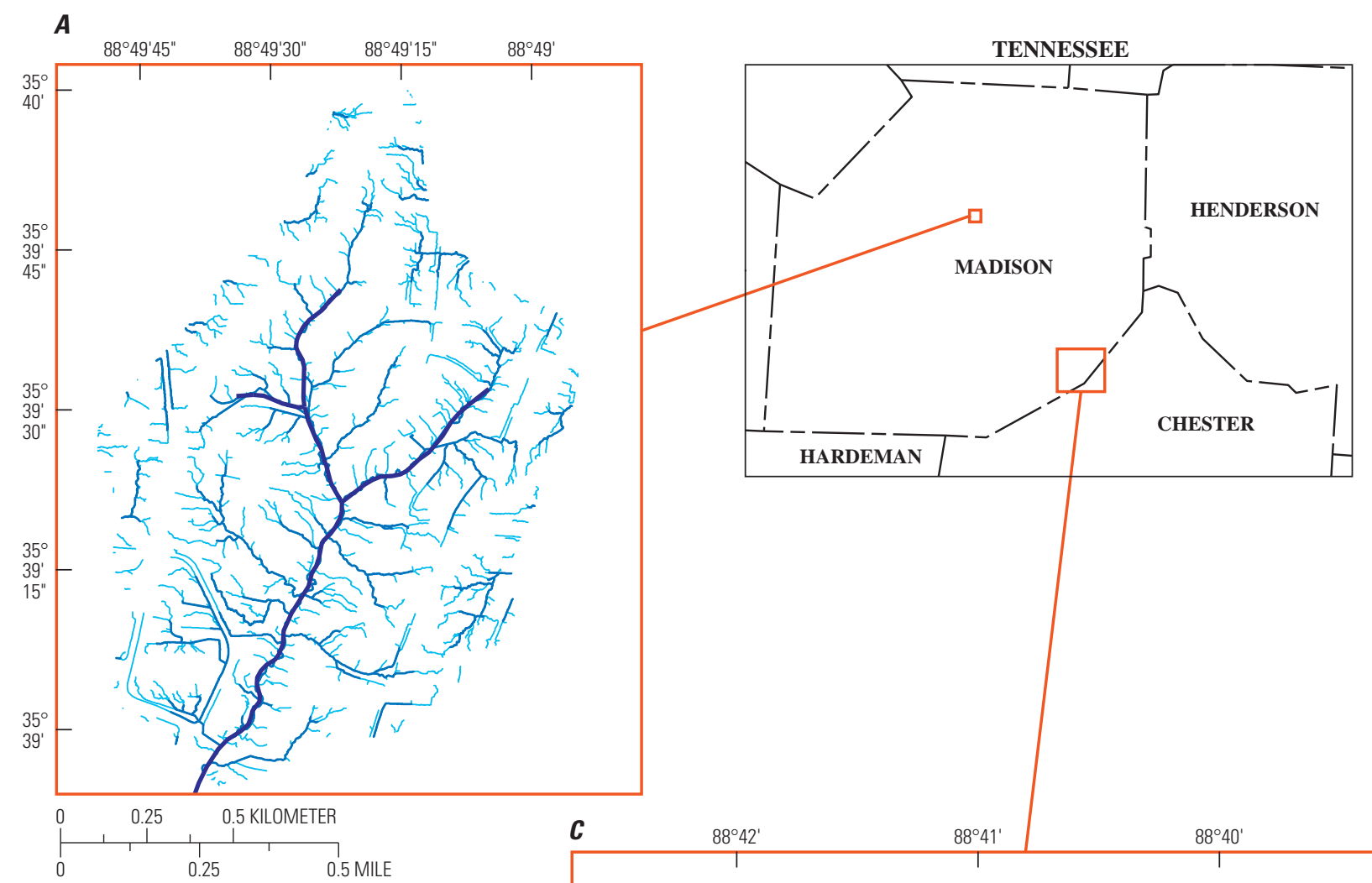

\section{$\boldsymbol{B}$}
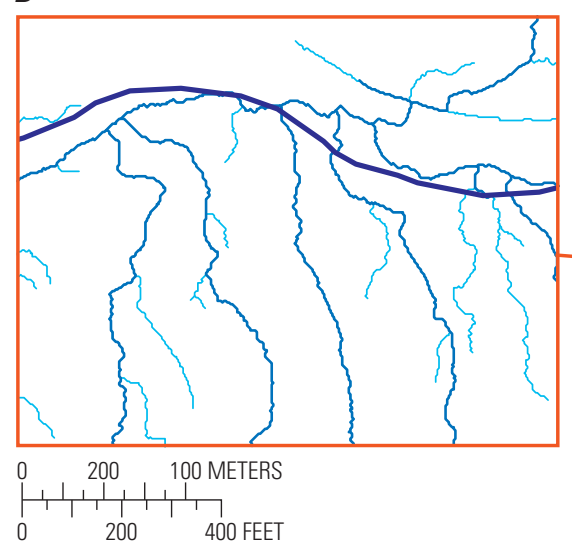

EXPLANATION

High-resolution (1:24,000) NHD flowlines

Flow Network tool output, 5,000-cell flow-accumulation threshold

Flow Network tool output, 1,000-cell flow-accumulation threshold

Gullied areas in Pinson Mounds State Archaeological Area

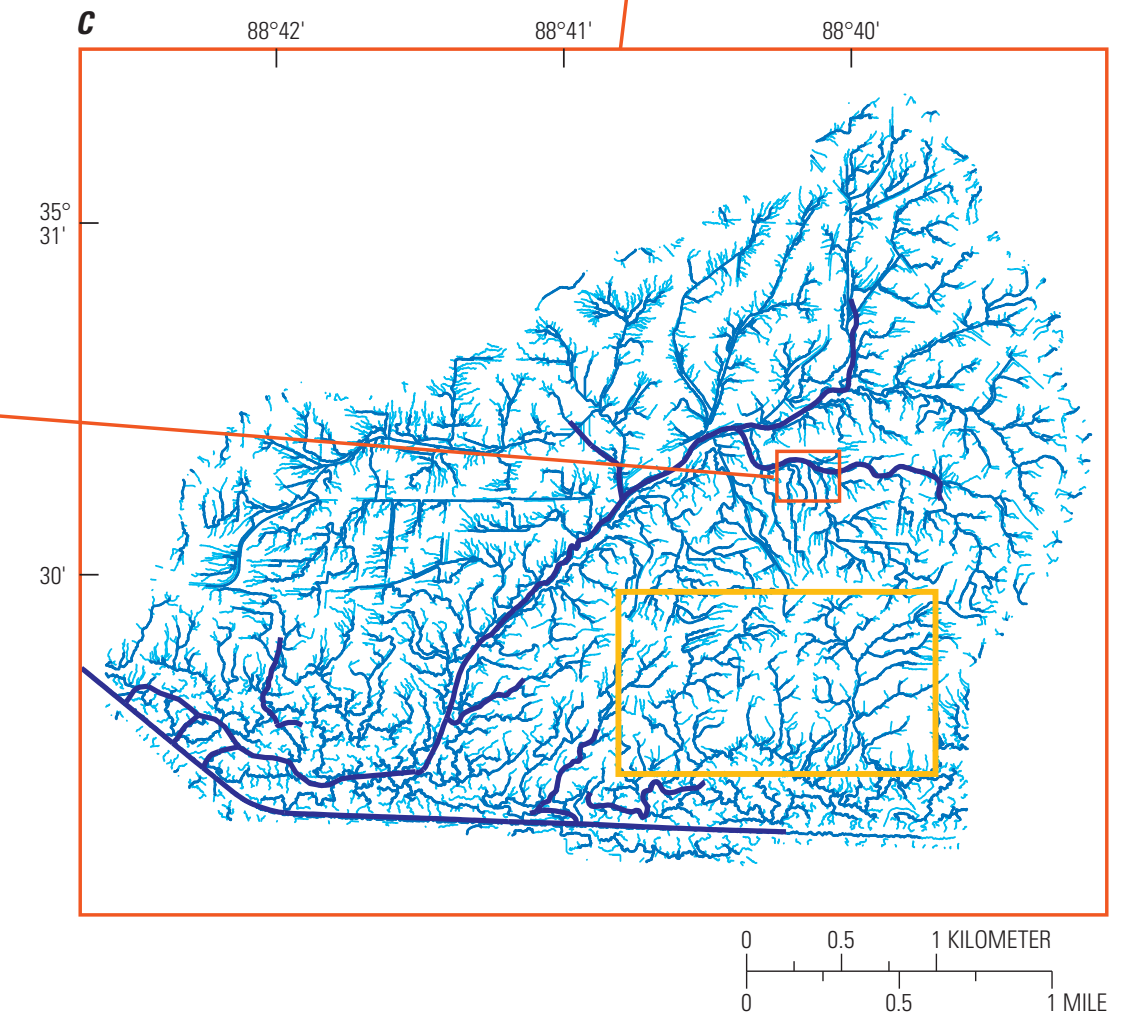

Base modified from U.S. Department of Agriculture, Natural

Resources Conservation Service, 1-meter-cell-size digital elevation model, 2011. Lambert Conformal Conic Projection, Horizontal datum: North American Datum of 1983), Vertical datum: North American Vertical Datum of 1988

Figure 6. Flow Network tool outputs compared to the high-resolution flowline from the National Hydrography Dataset (NHD) for the, $A$, Upper Sandy and, $B, C$, Pinson Mound study areas. 
Because the Flow Network tool delineates flow networks along cells having the lowest local elevation values, the mapped positions of resulting flow networks may be slightly different from those of actual stream centerlines. In some locations, the flow network appears to migrate in a sinuous fashion across the streambed. The accuracy of this geomorphology was assessed by field inspection. In most cases, such configurations represented the true geomorphology of streambeds, such as locations where highly sinuous stream channels are down-cutting into deposits of sediment. In a few cases, these apparent configurations may be byproducts of the analytical tools used to delineate flow networks, such as apparently sinuous "cuts" produced by the OPR tool. Where stream channels are very shallow or where flow passes over a vegetated surface without forming a distinct channel, small variations in elevation can divert the apparent flow direction derived from the DEM and create an artifact flow path; some such artifacts were located in the field. Local accumulations of woody debris also can obscure actual flow paths, causing erroneous delineation of flow paths over some short reaches.

An important limitation concerning the delineation of flow networks using lidar-derived DEMs is that where surface water is present at the time of lidar data collection, the lidar data represent water-surface elevations rather than bathymetric elevations (Charlton and others, 2003; Jones and others, 2008). As DEMs are prepared from raw QL2 lidar data, the hydroflattening process produces representations of water surfaces with constant elevation at all locations on the water surface for inland ponds and lakes of $8,000 \mathrm{~m}^{2}$ or larger (Heideman, 2014). For inland streams of at least 30-m nominal width, hydroflattening produces elevations that are level from bank to bank and that follow downhill gradients mirroring the surrounding terrain (Heideman, 2014). For stream channels that were inundated at the time of lidar data collection, the presence of water surfaces wider than the cell size of the resulting DEM obscures actual stream-channel geomorphology (Charlton and others, 2003) and may result in inaccurate flow-path locations within stream channels. Within the two study areas used to develop the DEM Geomorphology Toolbox, most stream channels contained ephemeral streams that were dry at the time of lidar data collection. Limitations related to inundation should be considered before applying the Flow Network tool to new study areas, as this and other tools in the DEM Geomorphology Toolbox were designed and calibrated for stream channels with sufficiently small drainage areas so that stream-channel geomorphology was not obscured by inundation.

In addition, it should be noted that the Flow Network tool and other tools in the DEM Geomorphology Toolbox were designed and calibrated for study areas having moderate topographic relief. Low-relief landscapes such as floodplains and river deltas, especially those having substantial areas of inundation at the time of lidar data collection and those where surface-water flow is bidirectional or divergent, may not be suitable for application of these tools and may be better analyzed by methodology developed by Jones and others (2008).

\section{Bank Slope}

In both study areas, the Bank Slope tool identified variations in channel bank slope along the flow networks (fig. 7). Slopes within a flow-corridor width of $60 \mathrm{ft}(18.3 \mathrm{~m})$ commonly exceeded 50 percent and in some locations exceeded 100 percent along the main stem of Sandy Creek and several of the larger tributaries in the Upper Sandy study area (fig. 7A). Similar results were obtained within the gully networks dissecting the bluffs on the southern boundary of the Pinson Mounds study area (fig. 7B).

Interpreting outputs from the Bank Slope tool requires awareness of several limitations. First, slope values produced by the Bank Slope tool may or may not be equivalent to those calculated from channel cross sections, because slope is calculated across the entire land surface within the user-specified flow corridor with the slope value for each cell calculated using the maximum elevation difference over the set of eight neighboring cells. In many—but not all—cases, this maximum elevation difference will occur in a direction roughly perpendicular to the direction of the channel thalweg.

Second, the spatial resolution of the input DEM constrains the Bank Slope tool's ability to accurately identify small, highly localized areas of steep slope. James and others (2007) demonstrated that cross sections produced from DEMs derived from lidar data at a nominal 3-m spacing underestimated gully depth and side slopes in permanent gully systems that are narrow and steep-sided. Using 1-m resolution DEMs as inputs, the Bank Slope tool also underestimated slope for certain small, steep, actively eroding streambanks within gully systems at Pinson Mounds. For example, an actively eroding and overhanging bank is present in a section of streambank that was identified by the Bank Slope tool as having slope exceeding 50 percent but not exceeding 100 percent (fig. 8).

Third, the flow-corridor width specified by the user represents the width over which the user believes steep slopes can deliver sediment directly to the stream channel, not the width of the channel itself. The Bank Slope tool requires the user to set a constant flow corridor width value for the entire study area. This is a limitation because study areas may contain stream channels of varying widths, some narrowly confined, others in broad flat-bottomed swales bounded by steep banks that are only intermittently near concentrated flow. Where flow-corridor width specified by the user is set equal to the bankfull width, the Bank Slope tool may not include all zones of steep bank slope that deliver sediment to the stream-channel network. Conversely, where the flow-corridor width specified by the user is much wider than the streamchannel width, the Bank Slope tool will probably highlight areas of steep slope that are not able to contribute sediment to the channel. 

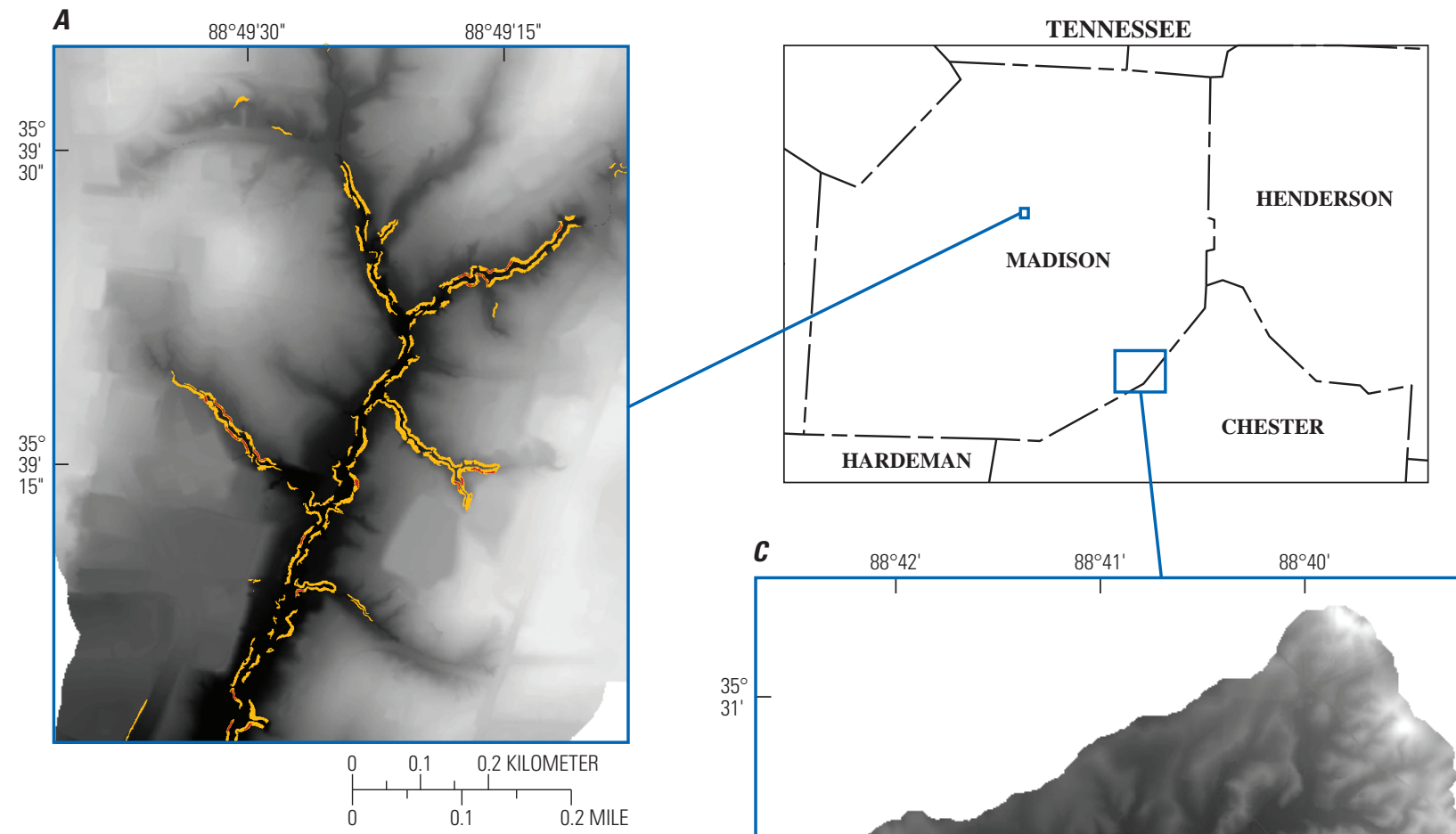

B
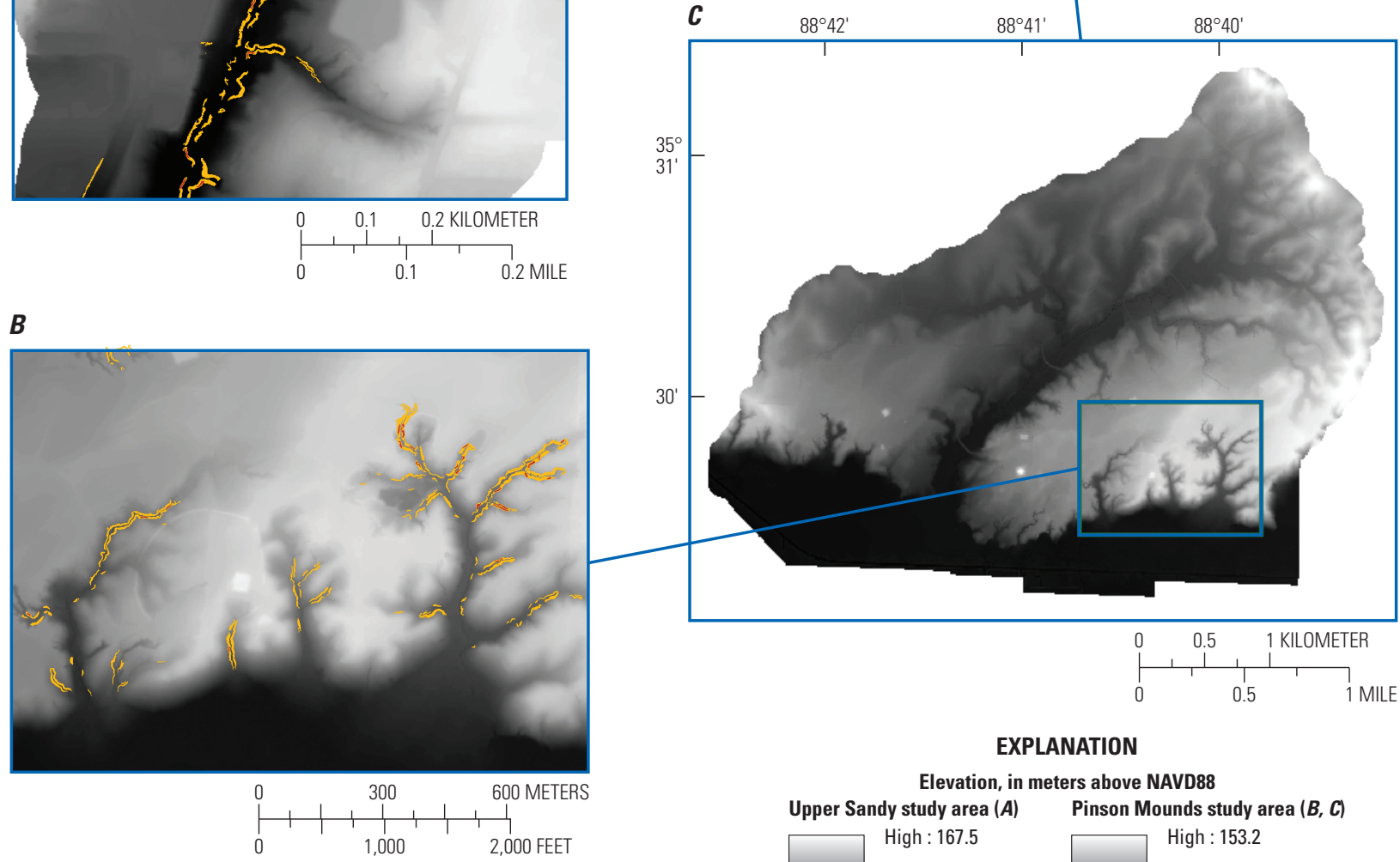

EXPLANATION

Elevation, in meters above NAVD88 Upper Sandy study area $(A) \quad$ Pinson Mounds study area $(B, C)$

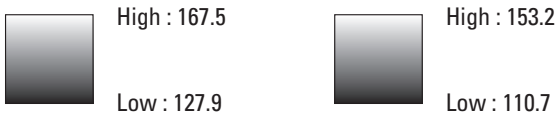

Output from the Bank Slope tool

Slope exceeds 100 percent

Slope exceeds 50 percent

Elevation data from U.S. Department of Agriculture, Natural Resources Conservation Service, 1-meter-cell-size digital elevation model, 2011. Lambert Conformal Conic Projection, Horizontal datum: North American Datum of 1983 (NAD 83), Vertical datum: North American Vertical Datum of 1988 (NAVD 88).

Figure 7. Outputs from the Bank Slope tool, $A$, within the Upper Sandy study area and, $B, C$, along gully networks within the Pinson Mounds study area. 


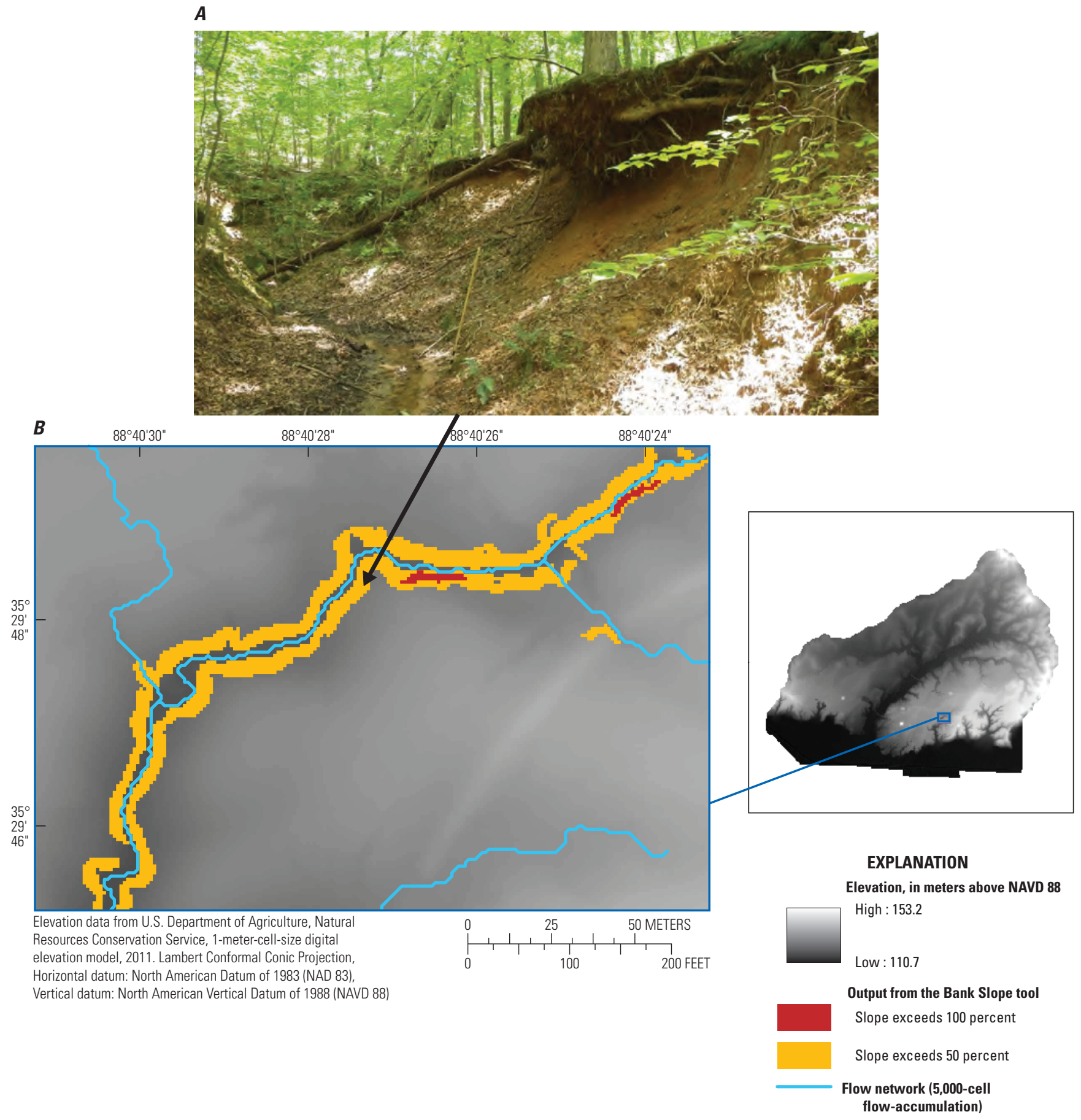

Figure 8. $\quad A$, An example of an actively eroding and overhanging bank in, $B$, a stream-channel section identified by the Bank Slope tool as having a slope exceeding 50 percent but not exceeding 100 percent in the Pinson Mounds study area. 
Fourth, the Bank Slope tool calculates slope only along the input flow network. Depending upon the flow-accumulation threshold used to produce the input flow network, the Bank Slope tool may fail to identify zones of steep bank slope upstream of the flow network. In cases where the user suspects this to be true, such as when polygons representing steep banks are truncated abruptly at the upstream ends of flow-network tributaries, the Bank Slope tool can be reapplied using a denser flow network produced by a lower flow-accumulation threshold.

Fifth, the Bank Slope tool does not differentiate actively eroding streambanks from stable, vegetated streambanks (fig. 9). At some locations in the Pinson Mounds study area, field inspection of steep bank polygons produced by the Bank Slope tool were found to represent steep but vegetated and probably stable sections of channel bank (fig. 9A). At other locations, the steep bank polygons were found to represent steep banks that were actively eroding and were probably contributing sediment into the stream-channel network, as indicated by exposed soil and overhanging roots (fig. 9B). Channel-bank stability is a function of several properties and processes in addition to slope, including physical soil properties, stream power, and types of vegetation present (Vandaele and others, 1996; Booth and Henshaw, 2001; Kirkby and Bracken, 2009). As a result, the Bank Slope tool alone cannot differentiate between actively eroding and stable streambanks. Instead, the tool can be used to identify zones of steep bank slope and these zones can be inspected in the field to determine their geomorphic stability and erosion risk.

\section{Channel Depth}

In both study areas, the Channel Depth tool indicated variations in stream-channel depth along the flow networks. Of particular interest were channel sections within the gully networks in the Pinson Mounds study area (fig. 10). Channel depth values were low upstream of gully heads, then increased rapidly as the flow network descended into a gully system (fig. 10A). The tool produced high channel-depth values in gully systems that were narrow and steep-walled (fig. 10B). Local decreases in channel depth values were produced along the flow network where the trench containing the active stream channel widened and the trench bottom contained an active floodplain, such as on the right side of the area shown in figure 10C. Tool output values also decreased at the downstream end of the gully system, where the flow network entered the floodplain of the South Fork Forked Deer River (fig. 10D).

Interpreting outputs from the Channel Depth tool requires awareness of several limitations. A primary limitation is that the tool applies a fixed, user-specified search radius across the entire study area. Results from the Channel Depth tool will vary with the search radius set by the user. Depending on stream-channel size, geomorphology, and the search radius applied, the tool may produce deeper or shallower values than the channel depth calculated from surveyed cross sections. Applying variable search radii was beyond the scope of this study; however, options exist for tool users to perform this type of analysis using a few additional steps. For example, the user could subdivide the input flow network into multiple flow networks, categorized by drainage area, and run the Channel Depth tool on each subdivided flow network. With each tool run, the user would set the search radius for the flow-network subset as deemed appropriate on the basis of drainage area or field measurements of channel width.

Because of the algorithm used by the Channel Depth tool, output values from this tool do not correspond to bankfull depth at most locations. Where the points within the userspecified search radius are all within the stream channel, such as in a wide braided reach, the tool output reflects the thalweg depth below in-channel bars. Where the highest points within the search radius are on the active floodplain, the tool output reflects the depth of the thalweg below the active floodplain. Where the stream channel is too narrow to be fully resolved by the DEM, however, such that elevations along the DEM-derived flow network are higher than actual thalweg elevations, the tool output underestimates channel depth. Where no distinct stream channel exists—as in the case of (1) alluvial fans, (2) valley bottoms and swamps with dispersed flow, and (3) small drainage areas - bankfull depth is undefined and the Channel Depth tool produces values reflecting local land slope. Lastly, in contexts of entrenched channels where the thalweg is near a steep slope of the adjacent terrace, the tool output reflects the height of the terrace slope within the search radius. Although this result greatly exceeds bankfull depth, it is valuable in indicating locations where flow is adjacent to steep banks. Along many stream channels, one bank is considerably steeper and (or) taller than the other. In such cases, the Channel Depth tool will produce depth estimates that are based on the height of the taller, steeper bank so long as both banks are within the user-specified search radius. As a result, the tool does not differentiate between stream channels having two tall, steep banks and stream channels having only one such bank.

Results from the Channel Depth tool should be interpreted cautiously with the aforementioned issues in mind and verified by field inspection. In the gully systems of the Pinson Mounds study area, field inspection of channel depth results indicated that the tool generally does not produce measurements of bankfull channel depth nor does it approximate measurements that would be obtained from surveyed cross sections. Nevertheless, the tool was effective in highlighting sections of channel adjacent to tall, actively eroding banks as well as incised channels in gully systems, both indicated by linear zones of high depth values. In addition, examining sections of the flow network with changing channel-depth values was useful in identifying gully heads (erosional features indicated by an abrupt increase in channel depth) and alluvial fan heads (depositional features indicated by an abrupt decrease in channel depth). 
A

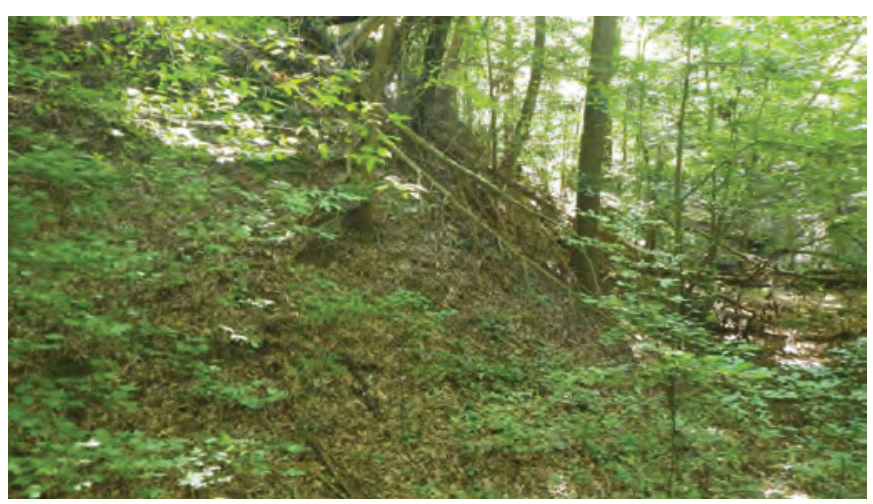

B

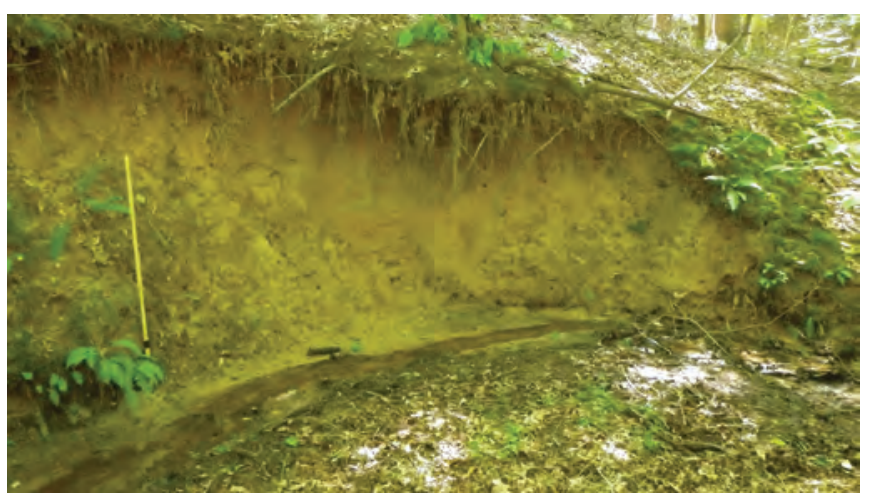

\section{C}

$88^{\circ} 40^{\prime} 35^{\prime \prime}$

8840'30"

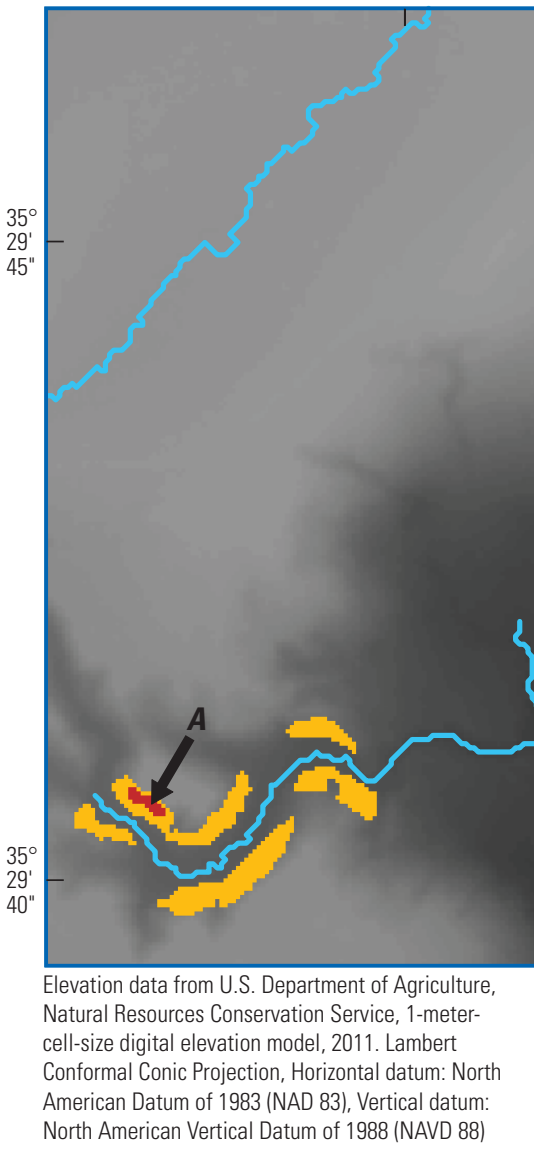

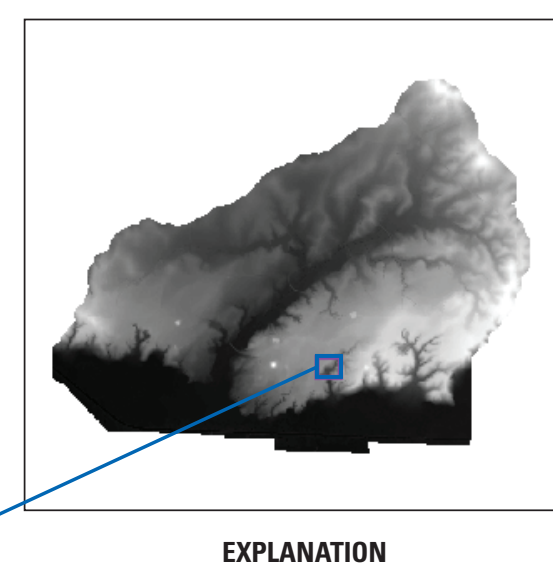

Elevation, in meters above NAVD88 High : 153.2

Low : 110.7

Output from the Bank Slope tool Slope exceeds 100 percent

Slope exceeds 50 percent

Flow network (5,000-cell flow-accumulation)

Figure 9. A, An area mapped with slope exceeding 100 percent that is vegetated and is probably stable, $B$, an area mapped with a slope exceeding 50 percent that shows signs of active erosion including exposed soil and overhanging roots, and $C$, output from the Bank Slope tool in the Pinson Mounds study area. 
A

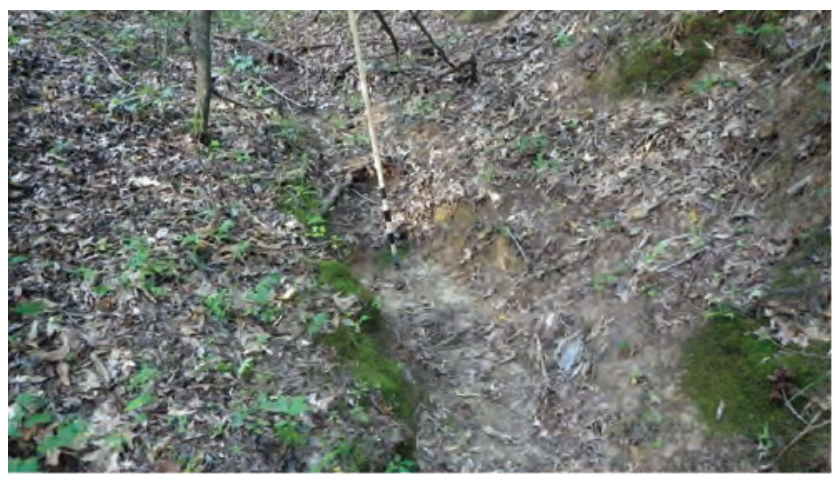

C

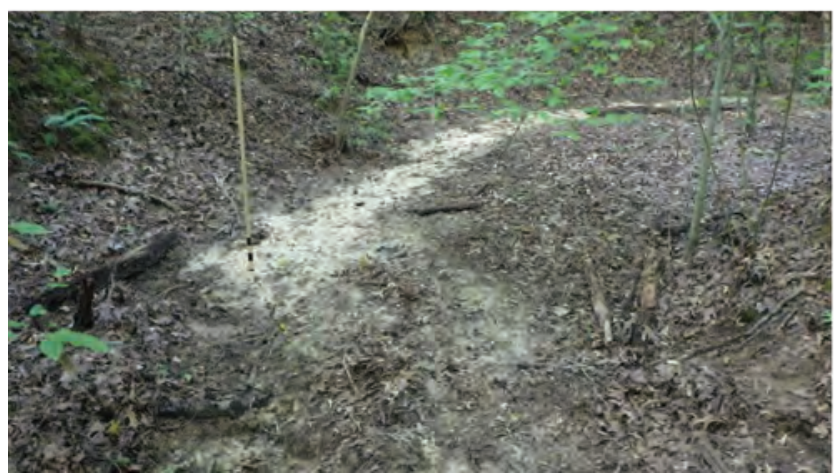

B

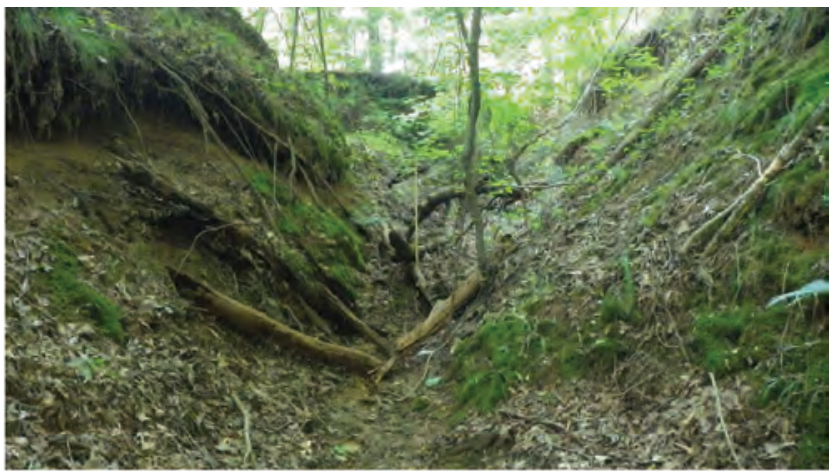

D

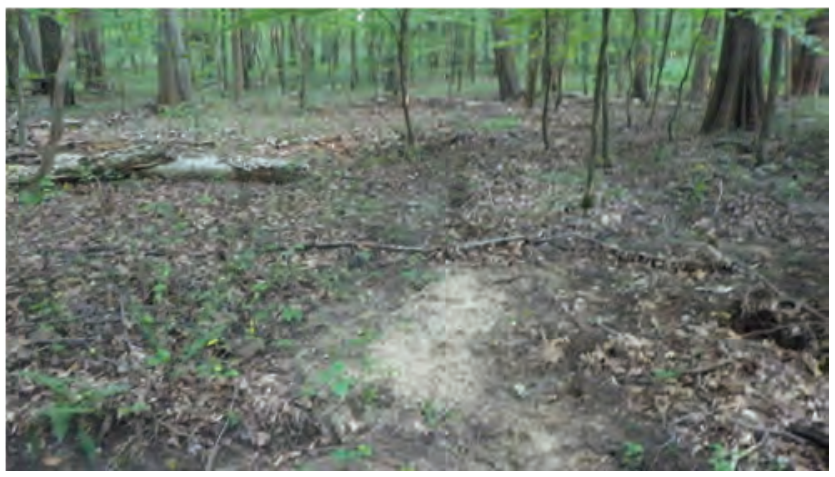

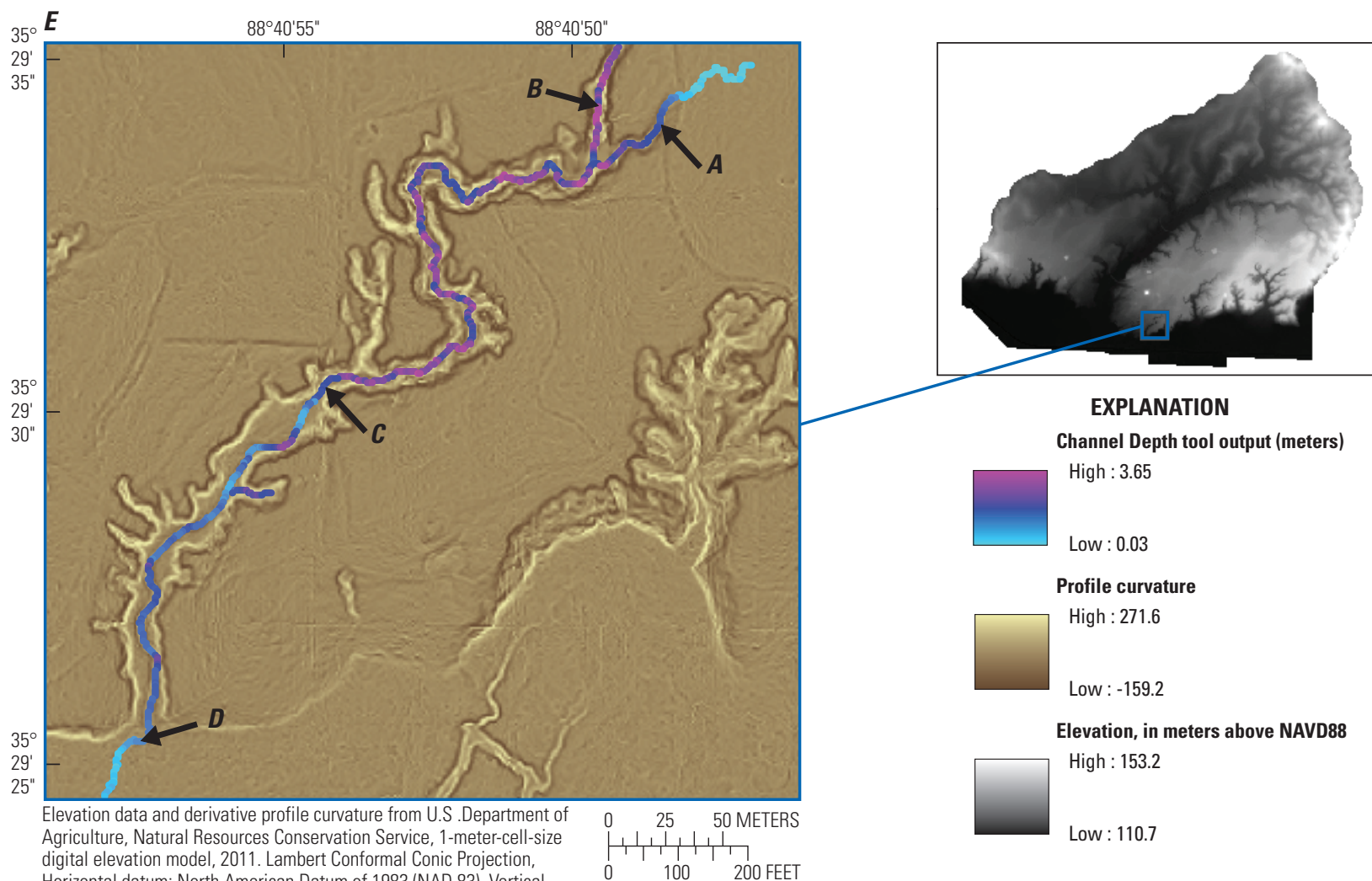

Horizontal datum: North American Datum of 1983 (NAD 83), Vertical

datum: North American Vertical Datum of 1988 (NAVD 88)

Figure 10. A, Upstream view of a gully head, $B$, upstream view of a narrow, steep-walled gully system, $C$, upstream view of a channel connected to a floodplain in the base of a trench, $D$, downstream view of the outlet of a gully system where flow enters the river floodplain, and $E$, calculated channel depth within gully networks using a 10-foot (3.05-meter) search radius, Pinson Mounds study area. 
Channel depth is one potential indicator of an erosional process known as channel incision. Factors contributing to the likelihood and rate of channel incision include erodible bed material and high stream power; stream power may increase in response to local changes in the channel or changes to the watershed (Schumm, 1979; Vandaele and others, 1996; Booth and Henshaw, 2001; Alonso and others, 2002; Poesen and others, 2003; Ferencevic and Ashmore, 2012; Daggupati and others, 2013). Channel incision can have multiple consequences for water quality and riparian habitat quality. Within incising channel reaches, consequences can include loss of aquatic habitat, increased erosion of channel banks, and the conversion of the former floodplain to an infrequently inundated terrace (Bradford and Piest, 1980; Booth and Henshaw, 2001; Kirkby and Bracken, 2009). Even after incision slows to apparent equilibrium, the resulting channel may lack desirable habitat features (Booth and Henshaw, 2001). Because channel incision contributes to sediment loads, the resulting downstream sedimentation can also affect aquatic habitat and exacerbate flooding in depositional areas. Barriers to sediment transport created by such deposition disconnect (or decouple) the downstream channel network from the upstream erosion (Happ and others, 1940; Pierce and King, 2007; Harvey, 2012; Katz and others, 2014).

\section{Channel Slope and Slope-Area Index}

The channel slope raster produced by the Channel Slope tool indicated slope values along flow networks as high as 377 percent in the Upper Sandy study area and as high as 114 percent in the Pinson Mounds study area (table 2). These raster output files did not differentiate slope values in the vicinity of stormwater-infrastructure features-which could be artificially high because of the process used to incorporate those features into the DEM-from those in the remainder of the flow network. By contrast, the point file produced by the Channel Slope tool excluded points within a 3.05-m buffer around culverts. Comparison of the raster results to the point results produced by the Channel Slope tool indicated that the highest slope values were all collocated with stormwaterinfrastructure features. Thus, these values were probably artifacts created by incorporation of those features into the DEM, because the maximum slopes in the point files were 52 percent and 61 percent for the Upper Sandy and Pinson Mounds study areas, respectively (table 2). Of the points with a slope greater than 2 percent (the output points of the Channel Slope tool), the majority were between 2 and 5 percent and only a small number exceeded 10 percent (table 2). In the Upper Sandy study area, points having slope values greater than 10 percent were typically in headwater tributaries to Sandy Creek rather than in the main stem of Sandy Creek. Channel slope values exceeded 10 percent immediately upstream of several tributary confluences with Sandy Creek. In the Pinson Mounds study area, several of the gullies draining into Hudson Branch and several gullies dissecting the bluff above the floodplain of the South Fork Forked Deer River included locations along the flow networks where the channel slope exceeded 10 percent.

When the Slope-Area Index tool was run using an exponent setting of 0.4 , an SAI threshold setting of 500, and an input flow network that had been produced using a flow-accumulation threshold of 5,000 cells, the tool produced 300 points in the Upper Sandy study area and 1,287 in the Pinson Mounds study area (table 3). Of these high-SAI points, each corresponding to the center of a $1-\mathrm{m}^{2}$ cell on the flow network, majorities in each study area were in cells having a channel slope greater than 5 percent, based on the output of the Channel Slope tool.

Table 2. Summary of channel slope values produced by the Channel Slope tool.

\begin{tabular}{|c|c|c|c|c|c|}
\hline \multirow{2}{*}{$\begin{array}{c}\text { Study } \\
\text { area }\end{array}$} & \multicolumn{2}{|c|}{$\begin{array}{l}\text { Range of channel slope values } \\
\text { produced by the Channel Slope tool, } \\
\text { minimum to maximum } \\
\text { (percent rise) }\end{array}$} & \multicolumn{3}{|c|}{$\begin{array}{l}\text { Percentage of points with channel } \\
\text { slope greater than } 2 \text { percent for } \\
\text { which channel slope was }\end{array}$} \\
\hline & Output raster file & Output point file & $\begin{array}{l}\text { Between } \\
2 \text { and } \\
5 \text { percent }\end{array}$ & $\begin{array}{l}\text { Between } \\
5 \text { and } \\
10 \text { percent }\end{array}$ & $\begin{array}{l}\text { Greater } \\
\text { than } \\
10 \text { percent }\end{array}$ \\
\hline Upper Sandy & $0-377$ & $0-52$ & 68 & 23 & 9 \\
\hline Pinson Mounds & $0-114$ & $0-61$ & 76 & 19 & 5 \\
\hline
\end{tabular}


Table 3. Summary of point values produced by the Slope-Area Index (SAI) tool.

[Tool parameter settings were as follows: exponent, 0.4; SAI threshold, 5,000. The input flow network was produced using a flow-accumulation threshold of 5,000 cells]

\begin{tabular}{l|c|ccc}
\hline \multirow{2}{*}{ Study area } & Number of high-SAl points & \multicolumn{3}{|c}{$\begin{array}{c}\text { Number of high-SAl points } \\
\text { with channel slope }\end{array}$} \\
\cline { 3 - 5 } & produced by the SAl tool & $\begin{array}{c}\text { Between } \\
\text { 5 and } \mathbf{1 0} \text { per- } \\
\text { cent }\end{array}$ & $\begin{array}{c}\text { Greater than } \\
\mathbf{1 0} \text { percent }\end{array}$ & $\begin{array}{c}\text { Total } \\
\text { (greater than } \\
\mathbf{5} \text { percent) }\end{array}$ \\
\hline Upper Sandy & 300 & 72 & 196 & 268 \\
Pinson Mounds & 1,287 & 366 & 548 & 914 \\
\hline
\end{tabular}

Both the Channel Slope tool and the Slope-Area Index tool were useful in identifying erosional features in both study areas, including features that were not apparent in aerial imagery. In the Upper Sandy study area, for example, a head cut $3 \mathrm{~m}$ tall is associated with four cells along the flow network with slope exceeding 10 percent and SAI exceeding 500 (fig. 11). This large erosional feature is not visible in the highest-resolution aerial imagery available for this study area, which is a $1-\mathrm{ft}(0.3-\mathrm{m})$ resolution, leaf-off orthophotograph obtained from the Tennessee Department of Transportation. Smaller erosional features detected by these tools included active and root-stabilized head cuts (examples in figs. 12A and 12B, respectively). These findings indicate that the resolution of 1-m DEMs and the analytic approaches of the Channel Slope tool and the Slope-Area Index tool can be useful in locating head cuts of varying sizes and morphologies within stream-channel networks.

Although the Channel Slope tool and the Slope-Area Index tool successfully identified head cuts in some cases, field inspection revealed a number of locations where these tools misidentified or failed to identify head cuts. Some of these locations represented omission errors, where head cuts were discovered by field inspections in stream-channel locations where no high-slope or high-SAI cells were identified by the tools, such as the head cut in figure 13A. Although the vertical drop of this feature is comparable to that of others successfully identified by the Channel Slope tool and the Slope-Area Index tool, field inspection of this head cut indicated that it did not represent a step in the thalweg profile. Immediately downstream of the plunge pool at the base of this head cut is a deposit of sand, shown in figure 13A,B with a clipboard resting at the upstream end of the deposit. Visual inspection in the field indicated the elevation of the deposit was only a few centimeters lower than the top of the root at the top of the plunge pool. The horizontal distance along the flow path from the top of the head cut to the upstream end of the deposition was estimated to be slightly less than $1 \mathrm{~m}$. Based on these observations, it is likely that either this site of geomorphic instability in the stream-channel network was too small to be resolved by the DEM, resulting in its failure to be detected by the Channel Slope tool or the Slope-Area Index tool, or that the DEM contained a single-cell depression that was filled by the OPR tool.

Commission errors also occurred in which high-slope or high-SAI cells along the flow network did not contain head cuts. For example, the section of stream channel shown in figure 13B contains no head cuts but corresponds to a flow-network cell with SAI exceeding 500, which was the user-specified SAI threshold used to identify high-SAI points in this study. Notably, the SAI value for the cell associated with this reach was 555, which does not greatly exceed the threshold. The Channel Slope tool did not identify this location as having steep slope; the maximum slope in a 5-cell neighborhood from this cell is 4.1 percent, with most cells having a slope of less than 2 percent. Users can adjust input parameters and interpretation of tool outputs to balance errors of omission and commission depending on management applications and local geomorphic and hydrologic factors. In landscapes prone to gully erosion, for example, management needs may prioritize the minimization of omission errors to ensure that few gullies are left undetected, resulting in a relatively high number of commission errors (Daggupati and others, 2013).

As the aforementioned examples illustrate, the Channel Slope tool and the Slope-Area Index tool are subject to a variety of limitations, such that tool users are advised to interpret tool results with caution and verify tool outputs in the field. Both tools are sensitive to the resolution of the input flow network. For example, both tools will fail to identify head cuts that are upstream of the input flow network; that is, at flow accumulations less than the threshold that was used to derive the input flow network. Additionally, both tools will probably fail to identify head cuts present at culvert outlets because of the way the Add Culverts tool incorporates culverts and other stormwater-infrastructure features into the DEM. The Add Culverts tool adjusts the elevation values of the input DEM along the length of each feature in the input vector file to equal the minimum elevation value crossed by that feature. These minimum elevation values typically occur at or near the downstream end of the feature, such as at a culvert outlet. 


\section{$\boldsymbol{A}$}

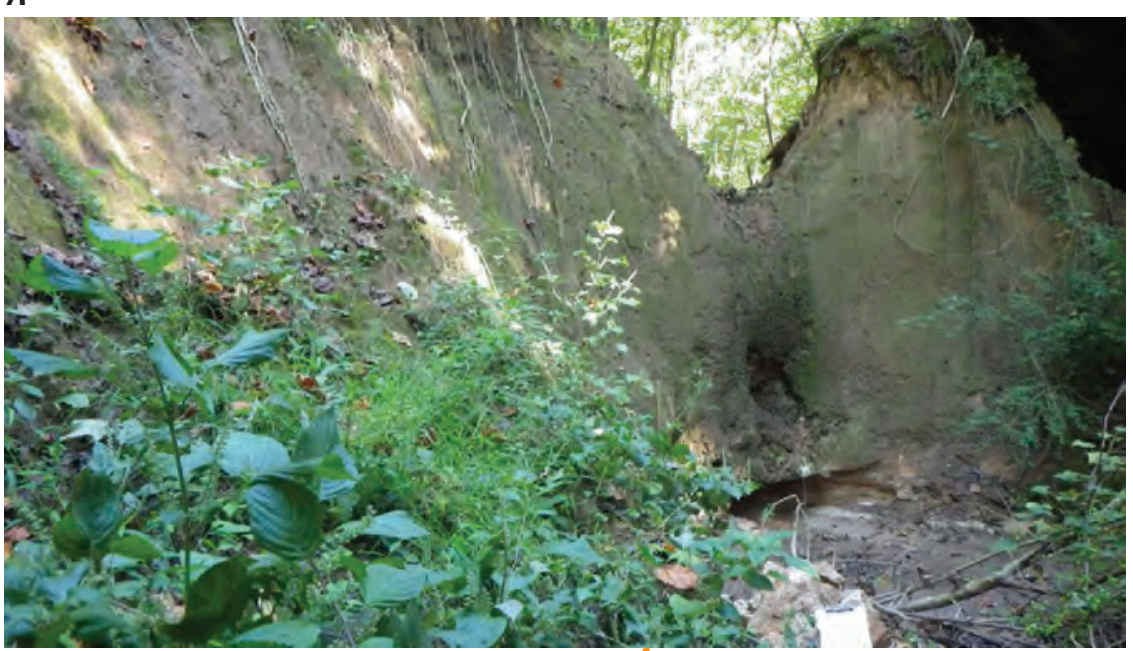

EXPLANATION

Elevation, in meters above NAVD88 High : 167.5

Low : 127.9

Flow network (5,000-cell flow-accumulation threshold)

- Channel Slope tool output exceeds 10 percent

- Slope-Area Index tool output exceeds $\mathbf{5 0 0}$

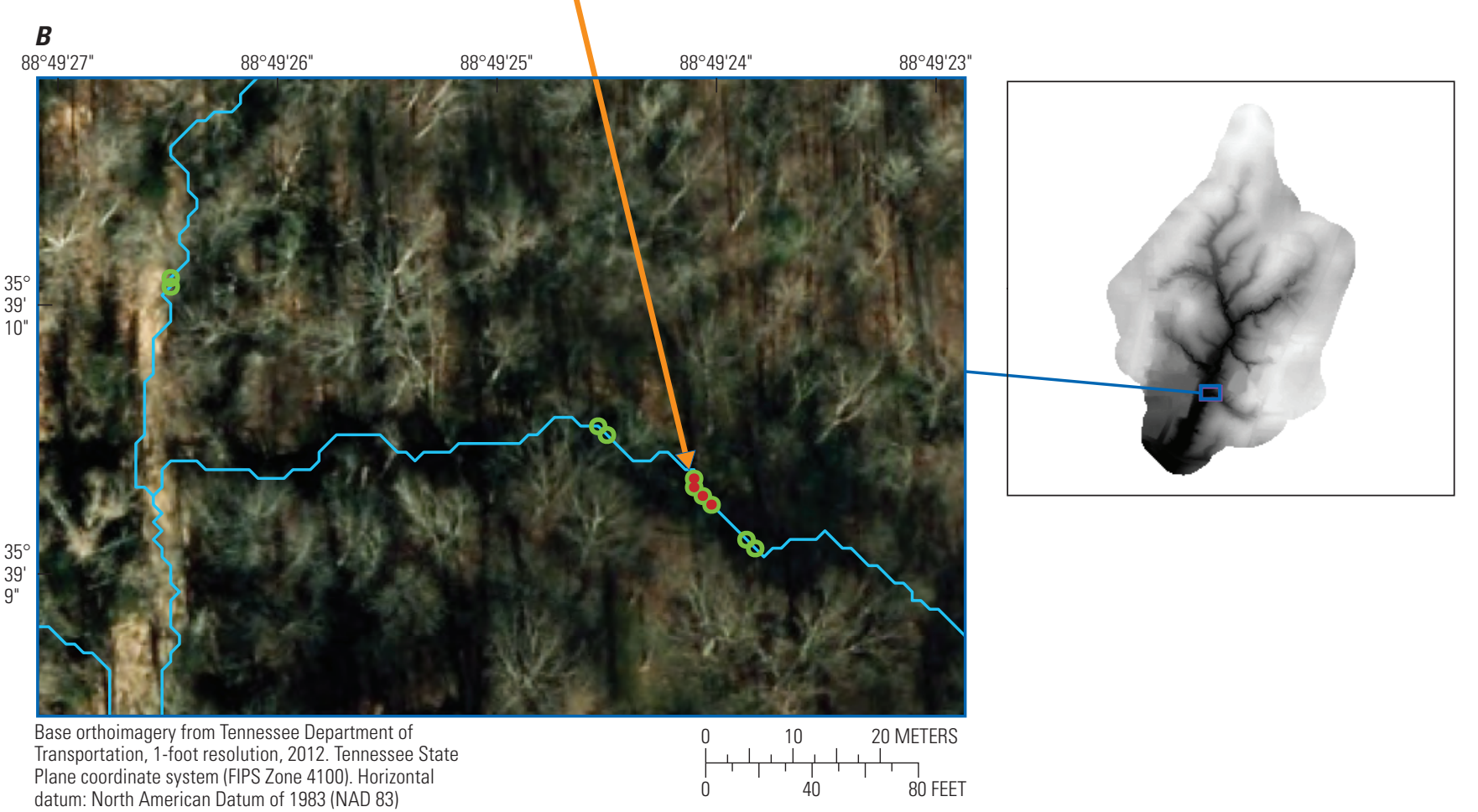

Figure 11. A, A head cut 3 meters tall that was not detectable from high-resolution aerial imagery but associated with, $B$, a flownetwork zone of steep slope and high slope-area index (SAI), Upper Sandy study area. 
$\boldsymbol{A}$

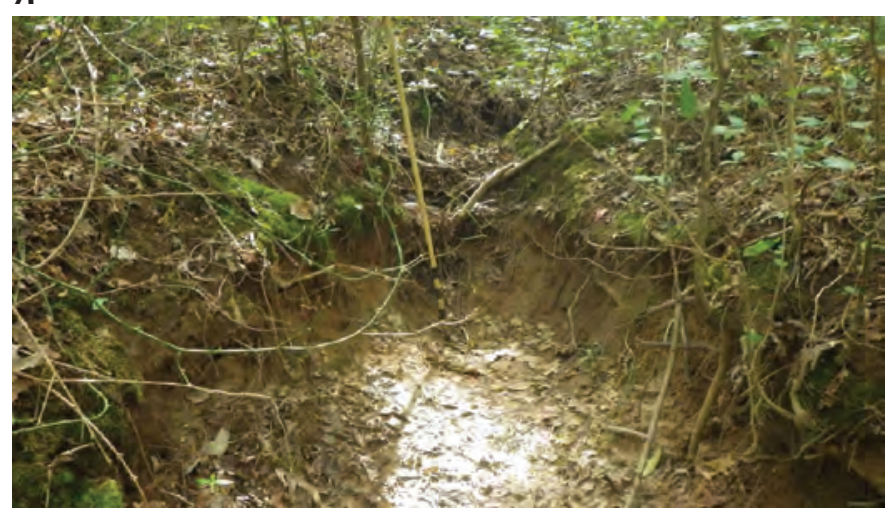

B

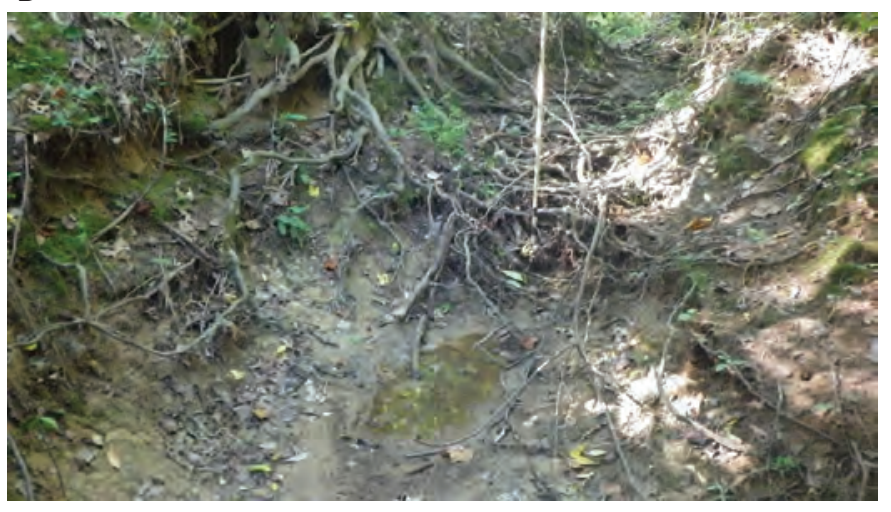

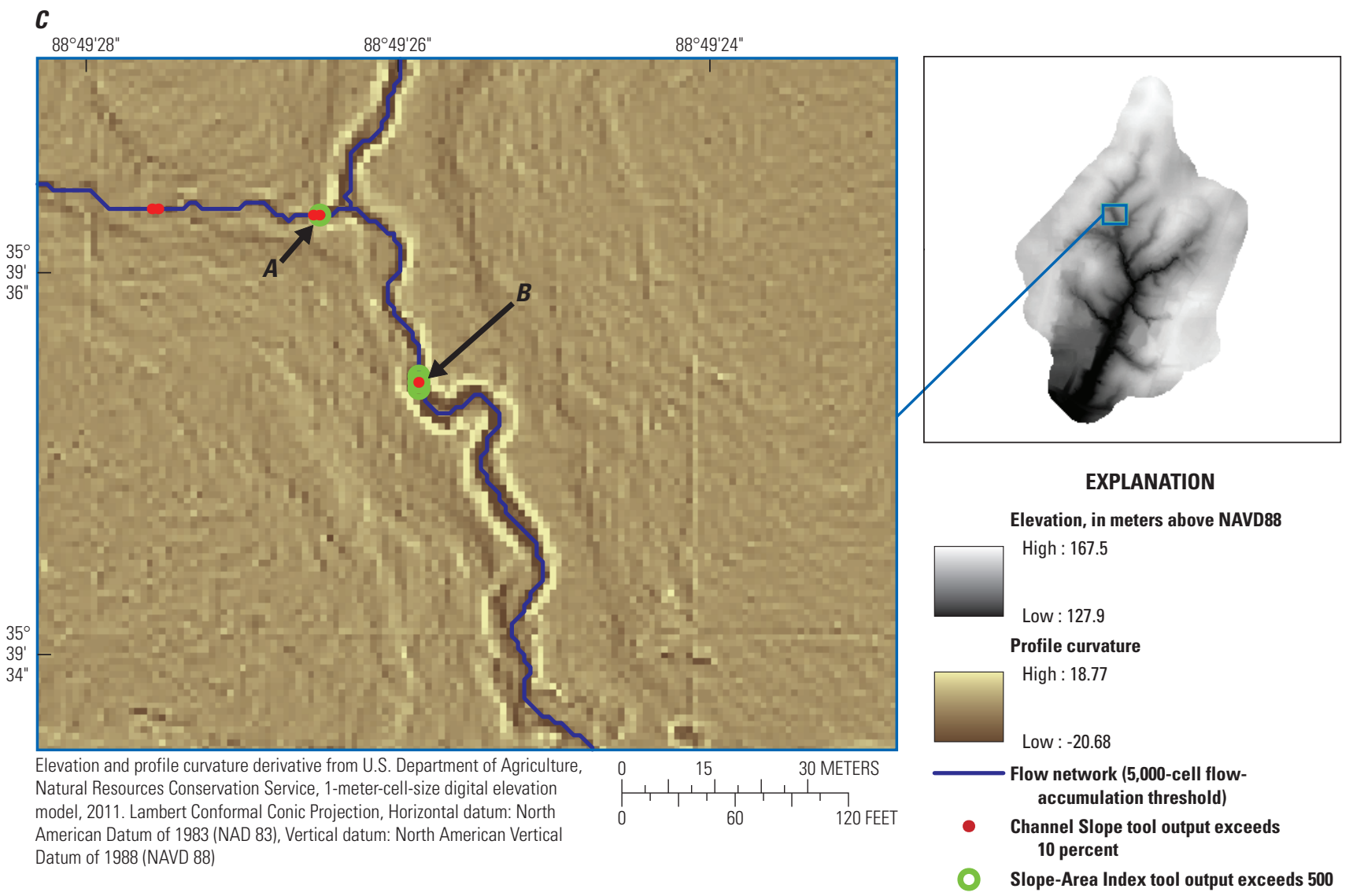

Figure 12. $A, 0.5$-meter-tall active head cut, $B$, a root-stabilized head cut, and $C$, output from the Channel Slope and SlopeArea Index tools, Upper Sandy study area. 
$\boldsymbol{A}$

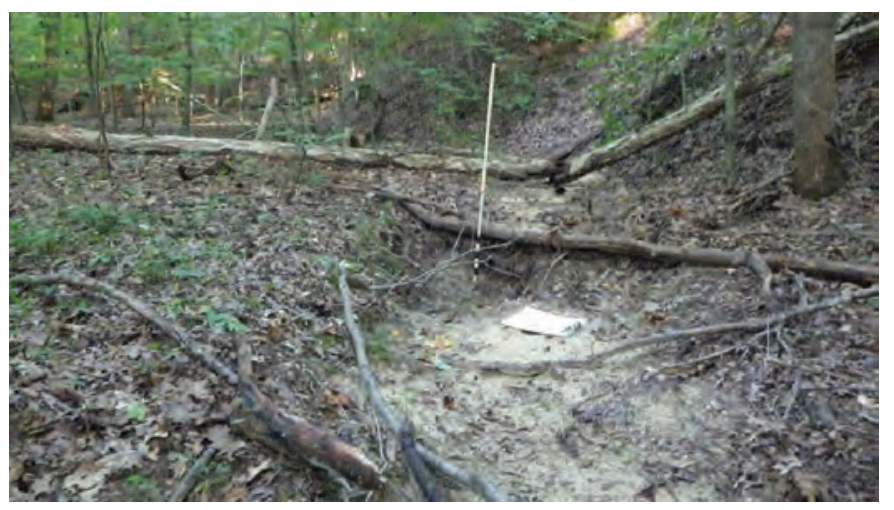

$B$

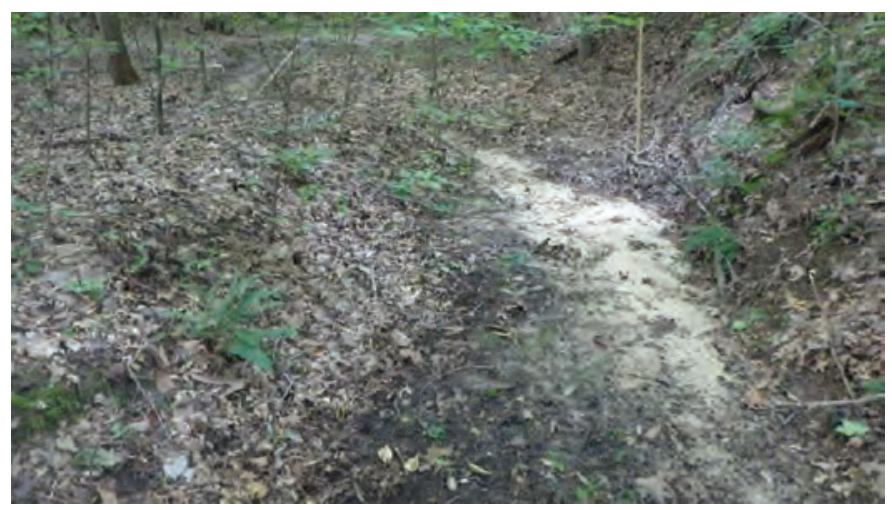

\section{C}

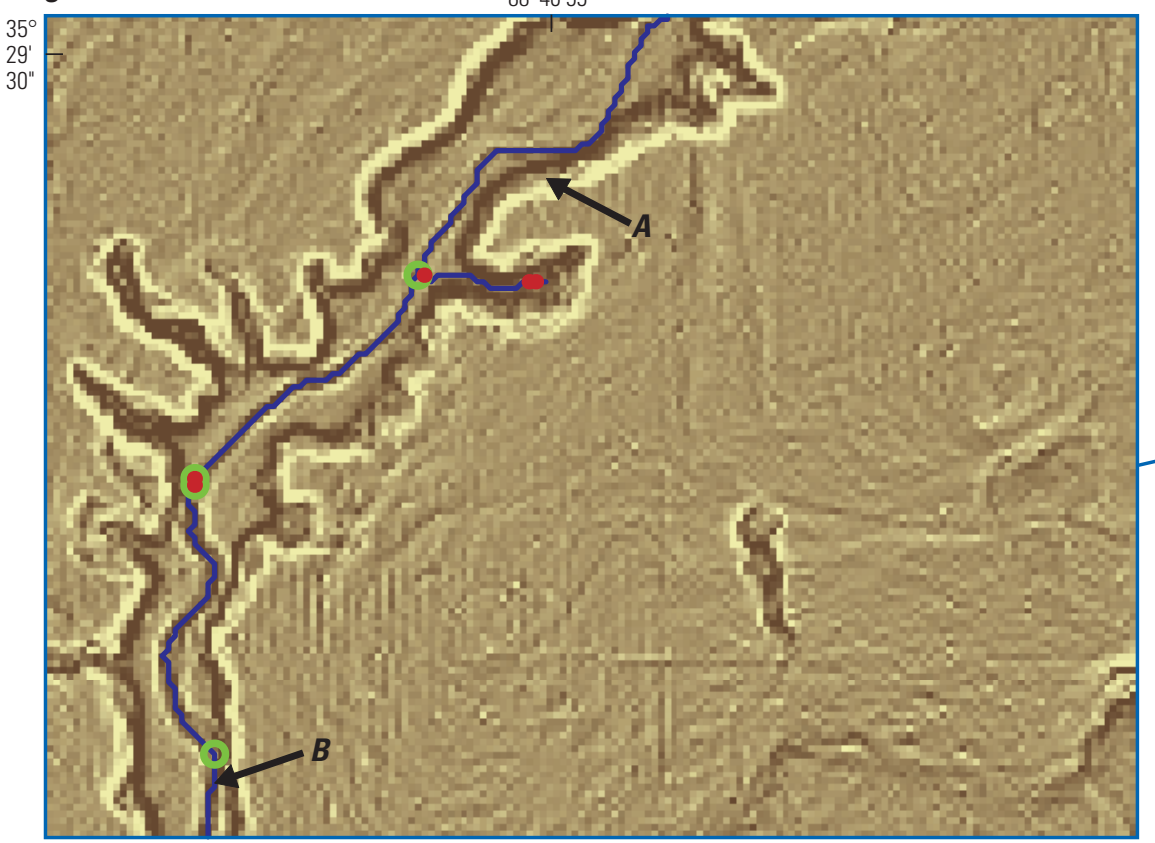

Elevation and profile curvature derivative from U.S. Department of Agriculture, Natural Resources Conservation Service, 1-meter-cell-size digital elevation model, 2011. Lambert Conformal Conic Projection, Horizontal datum: North American Datum of 1983 (NAD 83), Vertical
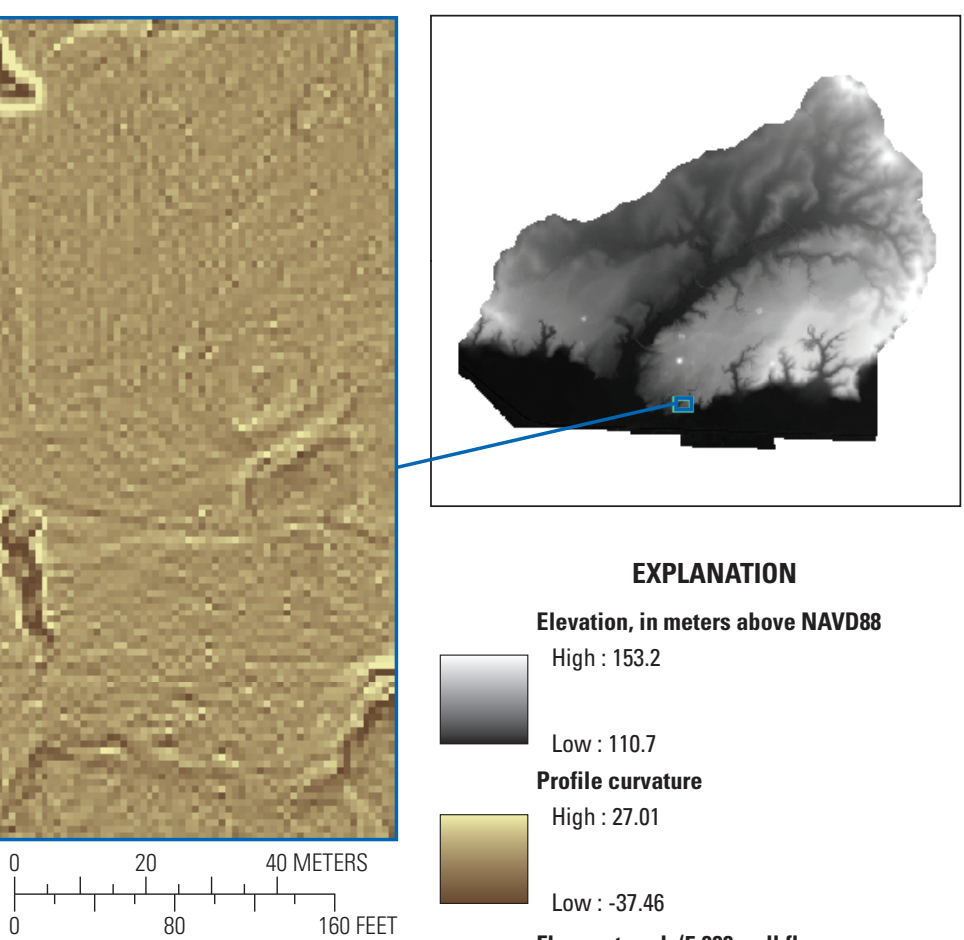

\section{EXPLANATION}

Elevation, in meters above NAVD88 High : 153.2

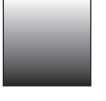

Low : 110.7

Profile curvature

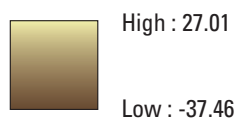
datum: North American Vertical Datum

accumulation threshold)

- Channel Slope tool output between 5 and 10 percent

Slope-Area Index tool output exceeds 500

Figure 13. Examples of errors produced by the Channel Slope tool and the Slope-Area Index tool, including, $A$, a head cut not identified by the tools, $B$, a location in the flow-network with high slope-area index (SAI) but no head cut, and $C$, tool outputs, Pinson Mounds study area. 
As a result, calculated channel slope values in the vicinity of culvert outlets are generally small, whether or not a steep slope associated with erosion was observed in the field.

For example, a culvert that crosses diagonally under a road in the Upper Sandy study area shows signs of erosion and woody debris accumulation at its outlet, including an approximately 0.25 - $\mathrm{m}$ vertical drop between the culvert apron and the stream channel below (fig. 14). Channel slope values produced by the Channel Slope tool are less than 2 percent in the vicinity of this culvert outlet and no high-SAI cells are present at the culvert outlet, reflecting the similarity between the modified (artificial) elevation values of the culvert and the elevation values along the flow network immediately downstream of the culvert. As is illustrated in figure 14, the culvert-modification process also results in confluences erroneously located inside culverts. Although these confluences produce artificially steep slopes in the output channel slope raster, the Channel Slope tool excludes output points in the immediate vicinity (10 ft, $3.05 \mathrm{~m}$ ) of the input stormwater-infrastructure features such that high-slope or high-SAI artifacts are not included in the vector output files at these locations.

Because the Channel Slope tool calculates slopes from one cell to another along flow networks, variability in channel slope may be present along any given reach. Although reach-scale averaging of channel slope was beyond the scope of this study, several options are available if the user wants to average channel slope across multiple cells. One option is to calculate a focal mean using the channel slope raster as the input and applying a desired radius within which to calculate mean values. A second option is to calculate the mean channel slope for each of the vector flow-line segments (line segments between confluences).

Because head cuts are defined by their abruptness (Montgomery and Dietrich, 1992; Montgomery and Foufoula-Georgiou, 1993), points along the thalweg with relatively high slope identify head cuts either at the upstream ends of gullies or elsewhere. Channel slope is also high at artificial or natural drops stabilized by rock or other resistant materials. Steep local drops stabilized by woody debris or roots may not currently exhibit the erosion and upstream migration typical of head cuts, but they have the potential to become head cuts through the decomposition or undermining of the woody material. The rates of head-cut erosion and upstream migration have been related to the height, steepness, and drainage area of head cuts along with other variables related to flow (Vandekerckhove and others, 2001; Alonso and others, 2002; Vandekerckhove and others, 2003; Rieke-Zapp and Nichols, 2011; DeLong and others, 2014). In general, changes in channel geomorphology that occur after lidar data collection will not be represented by tool outputs and may contribute to omission and commission errors. In this study, field investigation in 2015 suggested that several head cuts were located a few meters upstream from the locations indicated by the tool outputs produced using DEMs based on lidar data produced in 2011-12.
In general, the Channel Slope tool is likely to overpredict head cuts in small channels and underpredict it in larger channels, because it does not account for stream power. Stream power is a physical variable that represents the rate at which potential energy is expended in a stream channel as water flows downstream (Ferencevic and Ashmore, 2012). Stream power is a function of energy slope (approximated by water slope) and discharge; specific stream power is stream power per unit of stream-channel width (Ferencevic and Ashmore, 2012). Estimations of stream power or specific stream power were beyond the scope of tool development described in this report. However, the slope-area index can be a useful surrogate for stream power if discharge is assumed to be proportional to contributing drainage area (Ogren, 2012). Thus, the Slope-Area Index tool may be useful in some situations for identifying sites of geomorphic instability driven by stream power. In particular, slope-area index models have proven useful in predicting ephemeral gully development (Vandaele and others, 1996; Desmet and others, 1999; Daggupati and others, 2013) and in prioritizing implementation of best-management practices to mitigate erosion in agricultural landscapes (Ogren, 2012).

Because the Slope-Area Index tool allows the user to specify the exponent setting as well as the SAI threshold setting, spatial distributions of output points can be compared using different tool parameter settings. In general, when using the tool to identify possible locations of geomorphic instability in stream-channel networks, higher SAI threshold settings are expected to produce greater numbers of omission errors by failing to identify true sites of instability. Conversely, lower threshold settings would produce more commission errors by producing high-SAI points as tool outputs that do not correspond to sites of instability as indicated by field inspection. The tool parameter setting representing the exponent on drainage area in the calculation of slope-area index also influences the spatial configuration of results. In general, higher exponent settings are expected to shift the locations identified by the tool as having high SAI toward locations having larger drainage areas and less steep slopes, whereas lower exponent settings will preferentially identify steep locations with smaller drainage areas. Because both the SAI threshold and the exponent tool parameter settings are likely to affect tool outputs, users are encouraged to perform a thorough field verification of tool outputs, preferably with multiple tool parameter settings, to identify the optimal parameter settings for the study area and for the particular objectives of the investigation.

\section{Rough Terrain}

Application of the Rough Terrain tool to the culvert-modified, hydroconditioned DEM for the Upper Sandy study area using default tool settings produced an output file containing 58 polygons, ranging in size from $303 \mathrm{~m}^{2}$ to 


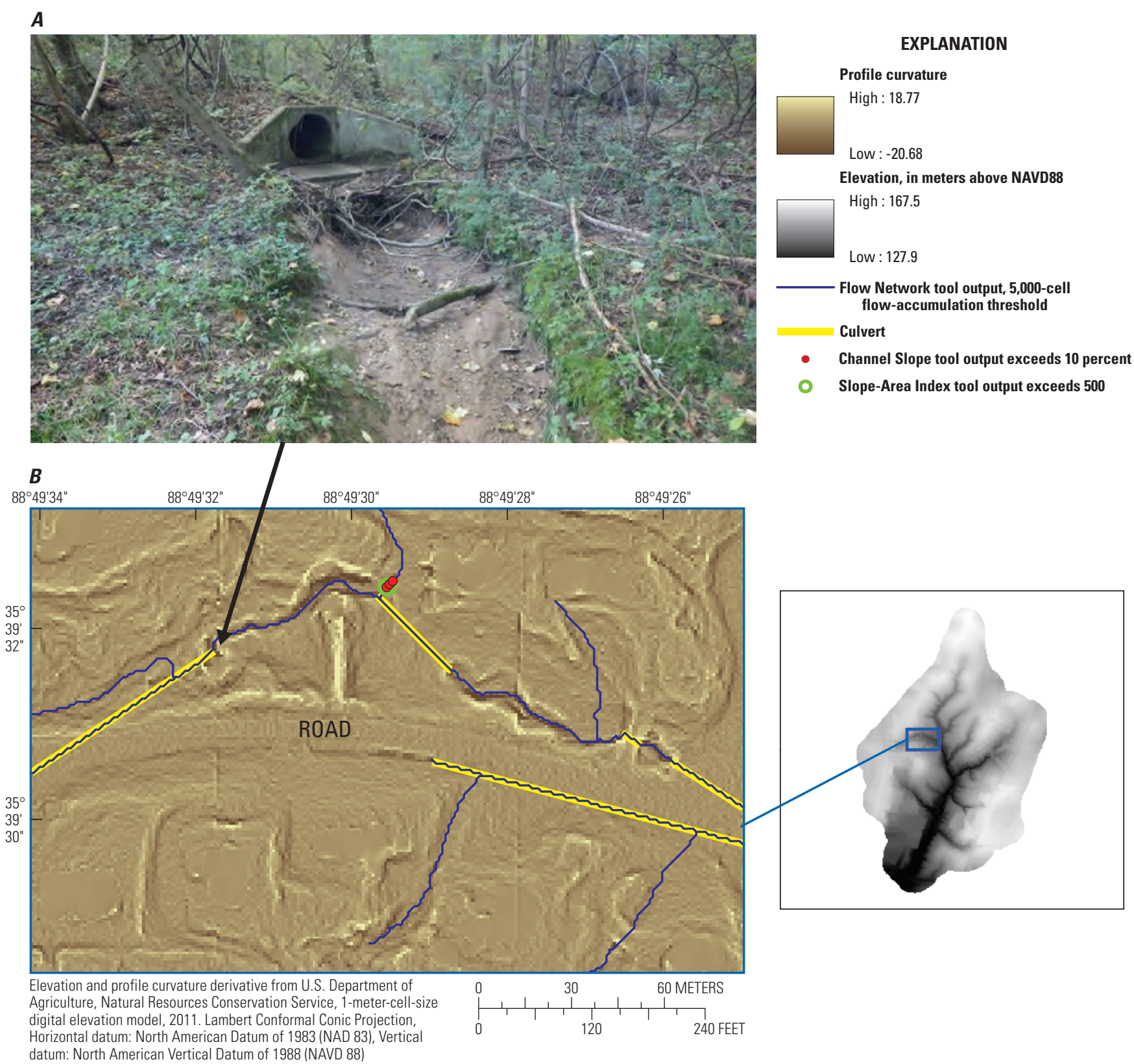

Figure 14. A, An example of erosion at a culvert outlet that was, $B$, not identified in Channel Slope tool or Slope-Area Index tool output, Upper Sandy study area. 
approximately 8 ha with a median of $441 \mathrm{~m}^{2}$. In the Pinson Mounds study area, the output file contained 307 polygons, ranging in size from $300 \mathrm{~m}^{2}$ to approximately 15.3 ha with a median of $581 \mathrm{~m}^{2}$.

Because the Rough Terrain tool processes data across the entire landscape and does not require a flow network as a data input, this tool is not sensitive to flow-network resolution (the flow-accumulation threshold that was used to create the input flow network), unlike the other tools described in this report. This quality of the Rough Terrain tool has advantages in some contexts. For example, the Rough Terrain tool highlighted a gully head in the Upper Sandy study area that is actively eroding urban infrastructure (fig. 15). Because this gully head has a relatively small drainage area, it was included on the flow network derived using a 1,000-cell flow-accumulation threshold (fine-resolution flow network) but not on the flow network derived using a flow-accumulation threshold of 5,000 cells (coarse-resolution flow network). As a result, this active and striking erosional feature was not identified by any of the other tools described in this report when the coarse-resolution flow network was used as the input. Other gullies having small drainage areas and eroded, kudzu-covered badlands were also successfully detected with this tool.

Results from the Upper Sandy study area indicate that the Rough Terrain tool identifies certain urban infrastructure features, such as stabilized steep embankments, retaining walls, and steep-sided ditches, in addition to gullied areas. For example, the Rough Terrain tool identified steep embankments in southwestern part of both maps in figure 16 as well as gullied areas in the north-central part of both maps. Rough-terrain polygons representing urban infrastructure features typically have distinctly linear boundaries and are commonly aligned with roads, building footprints, or property lines, enabling them to be visually distinguished as cultural features. These features may be at high risk for erosion when unmaintained and hidden from view in brush along rear property lines and hence may warrant inspection for signs of gully erosion.

\section{Topographic Position Index}

Visual inspection of the point locations resulting from TPI calculations indicated that calculated TPI values were of limited value in identifying depositional features such as alluvial fan heads. Many of the alluvial fan heads that are visually apparent in the three-cell-radius TPI raster for the Pinson Mounds study area were successfully identified by the aforementioned approach of analyzing TPI along flow networks, indicating that it produced relatively few omission errors. The approach produced a large number of commission errors; however, because many point locations were produced that did not correspond to any depositional feature. This preliminary assessment indicates the approach needs further refinement and calibration before it can be adapted into an informative tool for alluvial fan-head identification.
Therefore, no TPI-based tool was included in the DEM Geomorphology Toolbox.

\section{Spatial Analysis of Multiple Geomorphic Indicators}

When the tools in the DEM Geomorphology Toolbox described in this report were run on the input DEMs for the two study areas, areas of spatial overlap in tool outputs were apparent. Locations of densely concentrated features generated by two or more tools represent feature clusters. Figure 17 illustrates a feature cluster representing the head of a gully system in the Pinson Mounds study area. Field inspection indicated that this gully system contains multiple sites of active erosion including several head cuts, some exceeding $1 \mathrm{~m}$ in vertical drop (fig. 17A, B). These erosional features are located in feature clusters represented by outputs from multiple tools (fig. 17C). The clusters are contained within output polygons of the Rough Terrain tool and are located in flow-network sections more than $2.5 \mathrm{~m}$ deep, as indicated by output from the Channel Depth tool. Additionally, these active erosional features are in flow-network locations having a channel slope exceeding 10 percent based on Channel Slope tool output, SAI exceeding 500 based on Slope-Area Index tool output, and are adjacent to bank slopes exceeding 50 percent based on the Bank Slope tool output. Similarly, figure 18 illustrates a feature cluster in an entrenched reach of the main stem of Sandy Creek in the Upper Sandy study area. In this area, field inspection indicated a tributary gully (fig 18A) and a 3-m-tall overhanging bank (fig. 18B) were sites of active erosion. The tributary gully is within a flow-network section having a depth exceeding $2.0 \mathrm{~m}$, channel slope exceeding 10 percent, SAI exceeding 500, and adjacent bank slopes exceeding 50 percent (fig. 18C). The overhanging bank is on a flow-network section having a channel depth exceeding $4.5 \mathrm{~m}$ and adjacent bank slopes exceeding 100 percent. Both are located within polygons produced by the Rough Terrain tool that effectively outline the entrenched reach.

Feature clusters produced by running multiple tools on the same input DEM may be useful for prioritizing resource deployment for field investigation, because they represent possible erosional features as indicated by multiple complementary analytical methods. For example, although the Bank Slope tool and the Channel Slope tool both use slope calculations, the former focuses on the larger flow corridor whereas the latter focuses on slope along the flow network. The Rough Terrain tool is unique from the other tools in this report in two respects: it includes analysis of profile curvature and it does not limit analysis to the immediate vicinity of flow networks. The Channel Depth tool identifies maximum vertical distances present within a user-defined search radius and thus provides information that is complementary, not redundant, to slope-based indicators. As a result, feature clusters suggest that multiple approaches to deriving geomorphic indicators from the DEM converge spatially on locations of geomorphic instability. 
$\boldsymbol{A}$

B

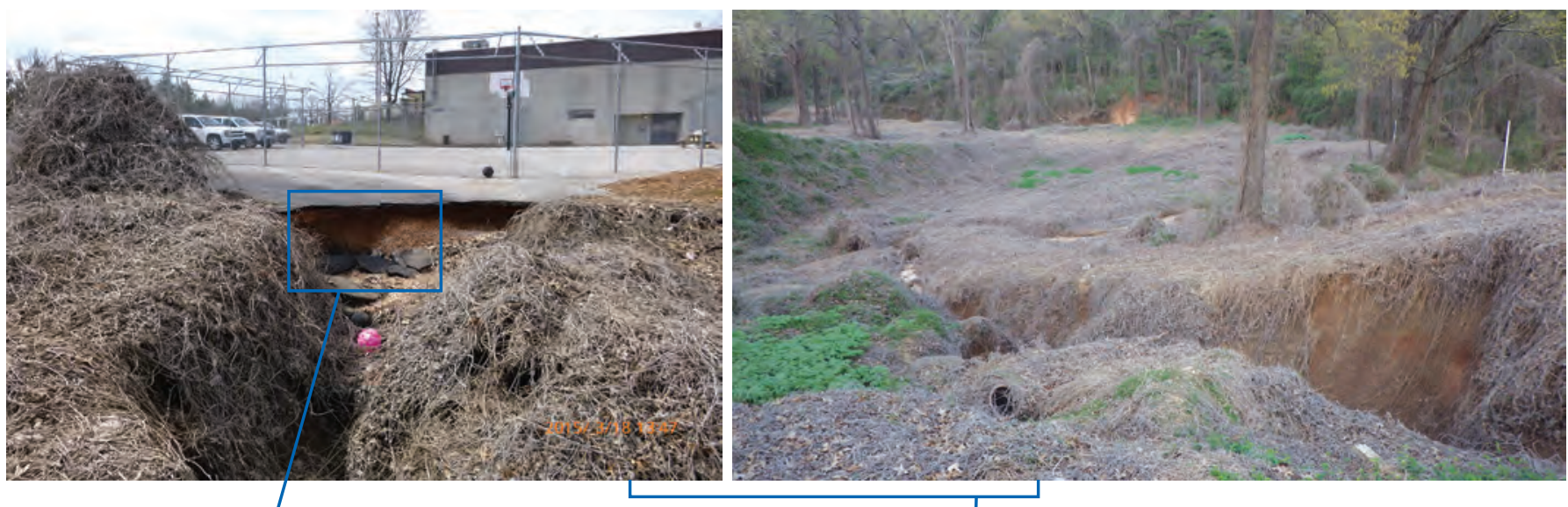

C

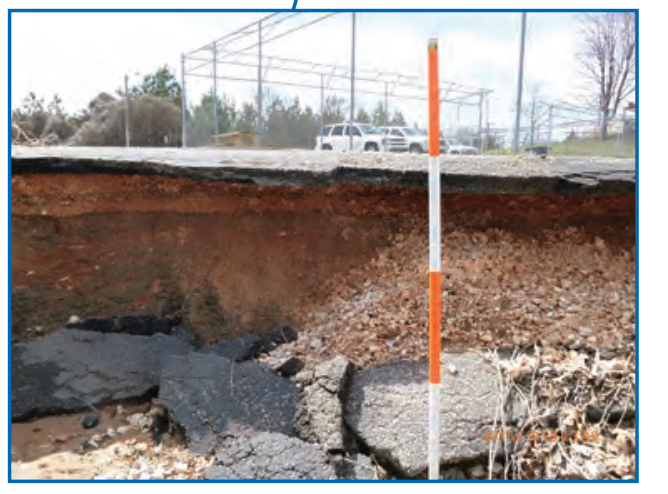

D

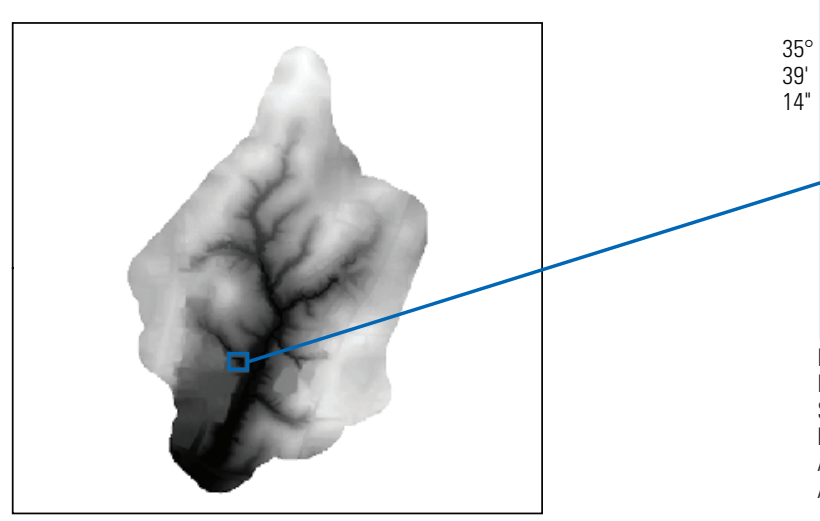

Elevation, in meters above NAVD88 High : 167.5

EXPLANATION

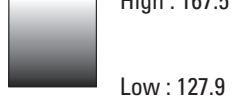

Department of Agriculture Natural Resources Conservation Service, 1-meter-cell-size digital elevation model, 2011.

Lambert Conformal Conic Projection, Horizontal datum: North

American Datum of 1983 (NAD 83), Vertical datum: North

American Vertical Datum of 1988 (NAVD 88)

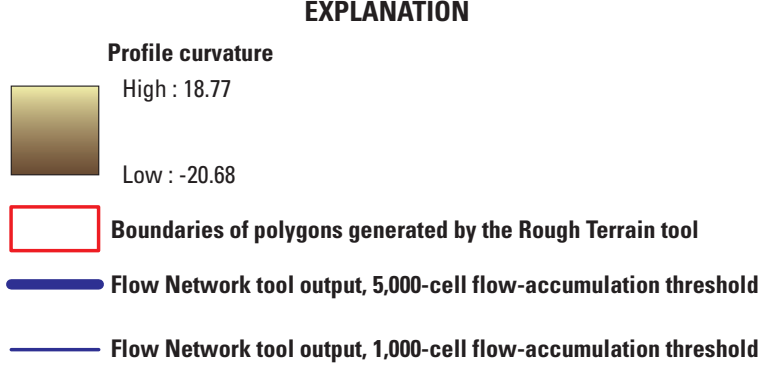

Figure 15. An example of a gully head eroding urban infrastructure, including, $A$, an upstream view of the gully head, $B$, a downstream view of the gully, $C$, a close-up view of the eroded area undercutting asphalt, and $D$, boundaries of polygons generated by the Rough Terrain tool, Upper Sandy study area. 
$\boldsymbol{A}$

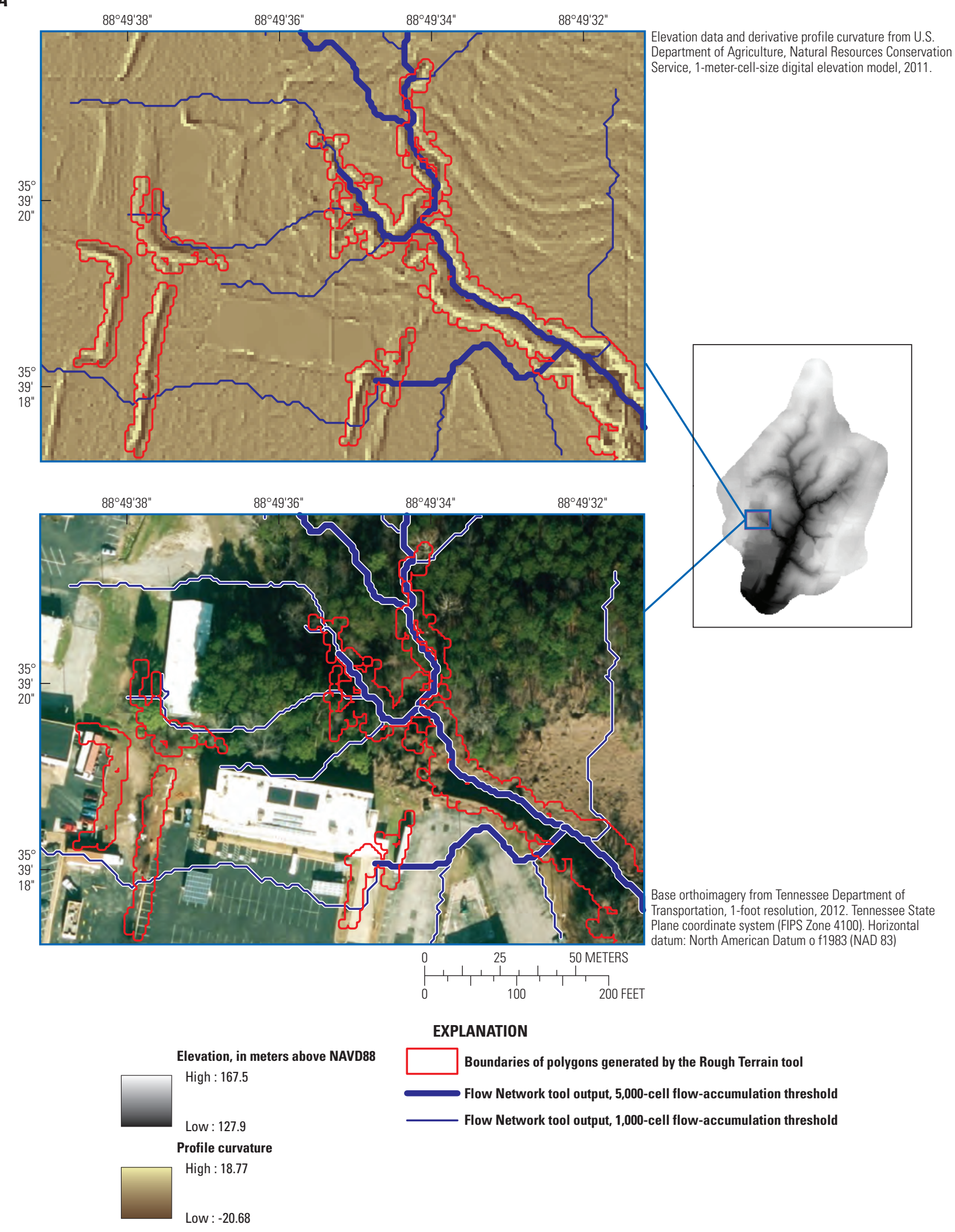

Figure 16. Output polygons from the Rough Terrain tool superimposed on, $A$, profile curvature derived from the digital elevation model (DEM), and on, $B$, aerial orthoimagery of identical extent, Upper Sandy study area. 
$\boldsymbol{A}$

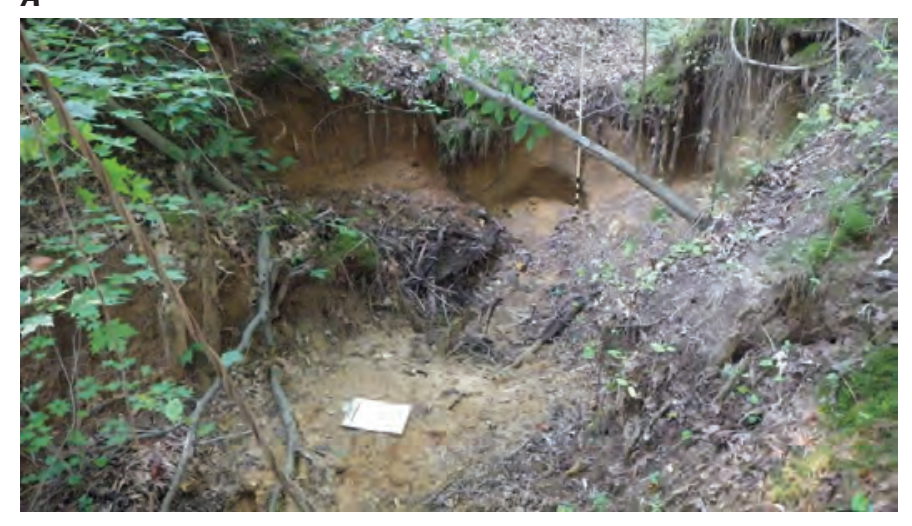

B

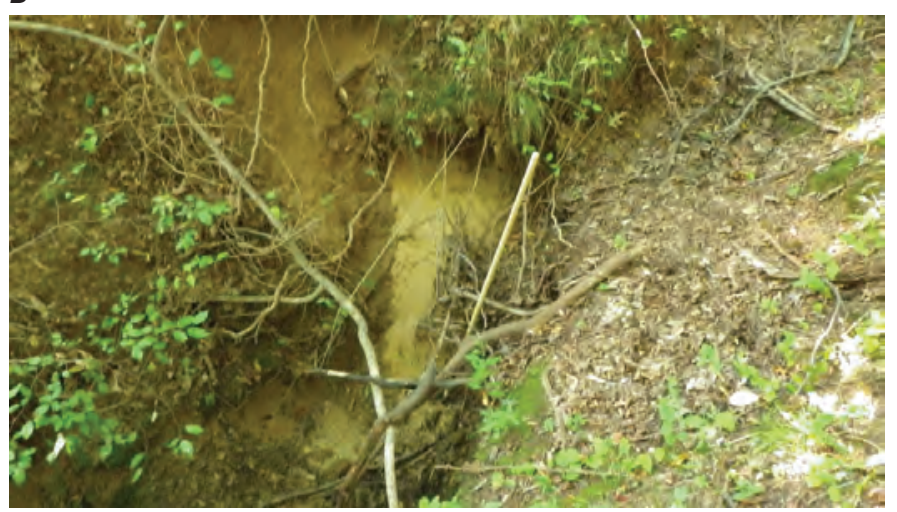

C $88^{\circ} 40^{\prime} 55^{\circ}$

$88^{\circ} 40^{\prime} 50^{\prime \prime}$

$88^{\circ} 40^{\prime} 45^{\prime \prime}$

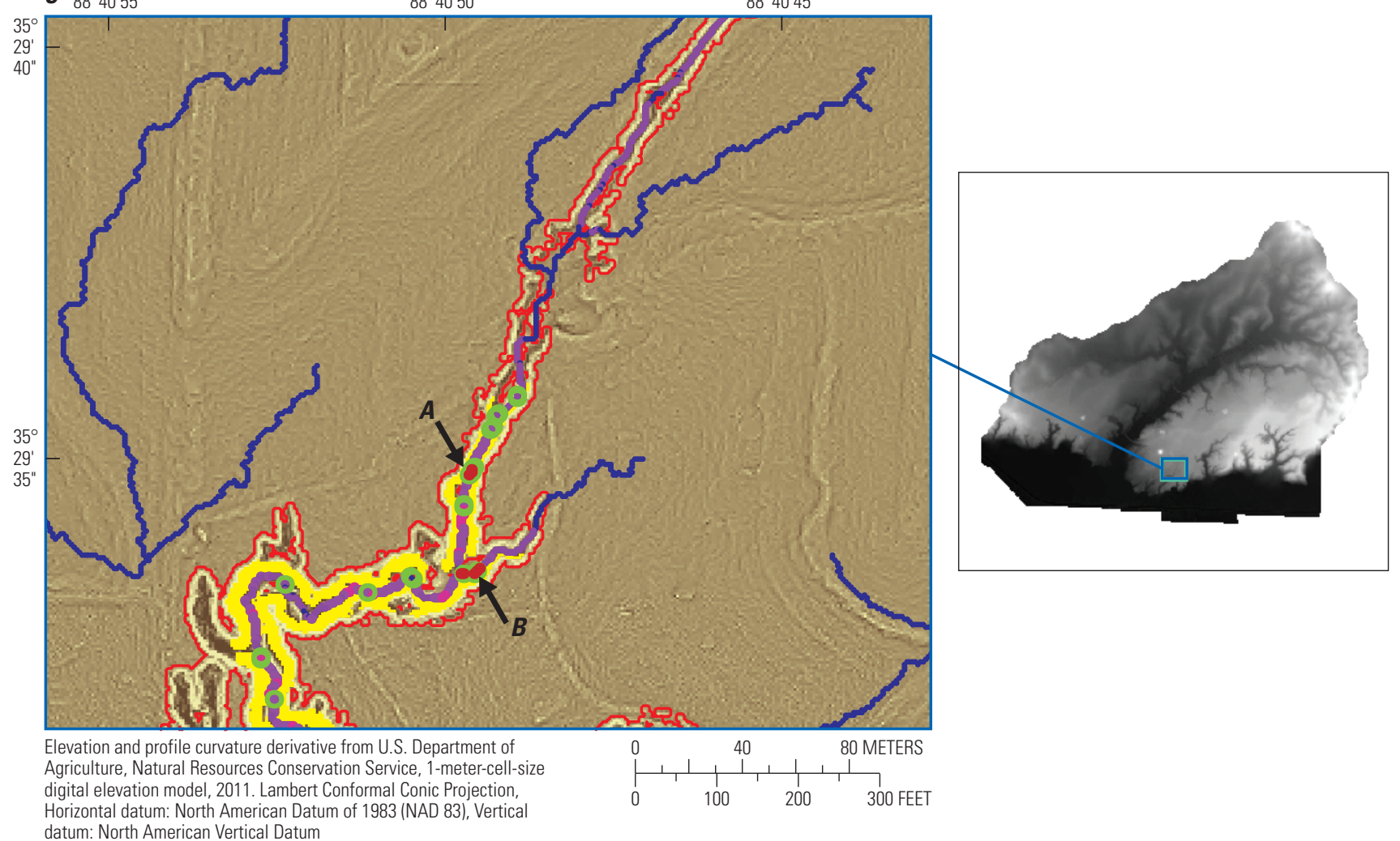

Horizontal datum: North American Datum of 1983 (NAD 83), Vertical datum: North American Vertical Datum

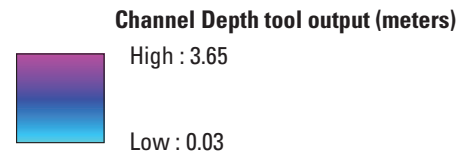

Profile curvature

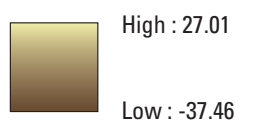

Elevation, in meters above NAVD88

High : 153.2

Low : 110.7

\section{EXPLANATION}

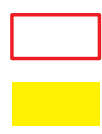

Boundaries of polygons generated by the Rough Terrain tool

Bank Slope tool output exceeds 50 percent

- Channel Slope tool output exceeds 10 percent

- Slope-Area Index tool output exceeds $\mathbf{5 0 0}$

Figure 17. Actively eroding head cuts in, $A$, the main channel of a gully system, and $B$, a small tributary to the gully system, associated with, $C$, feature clusters of outputs from multiple tools, Pinson Mounds study area. 
A

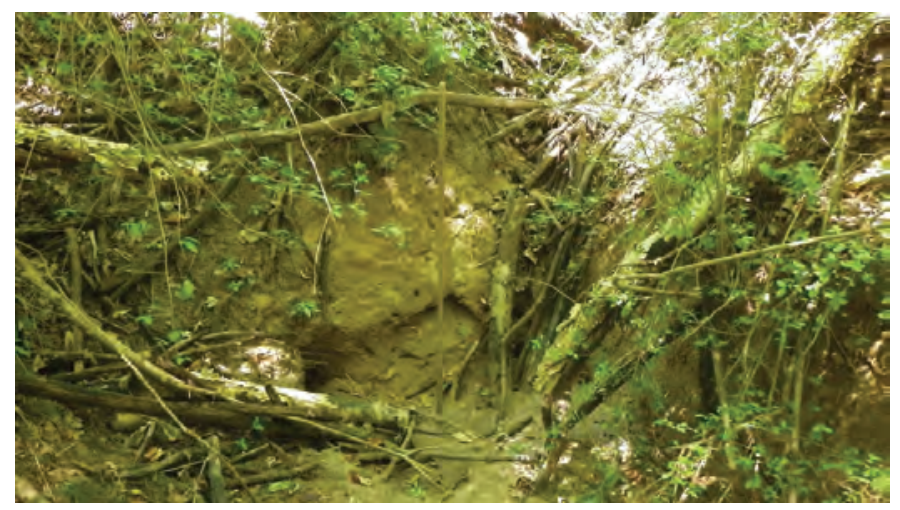

$B$

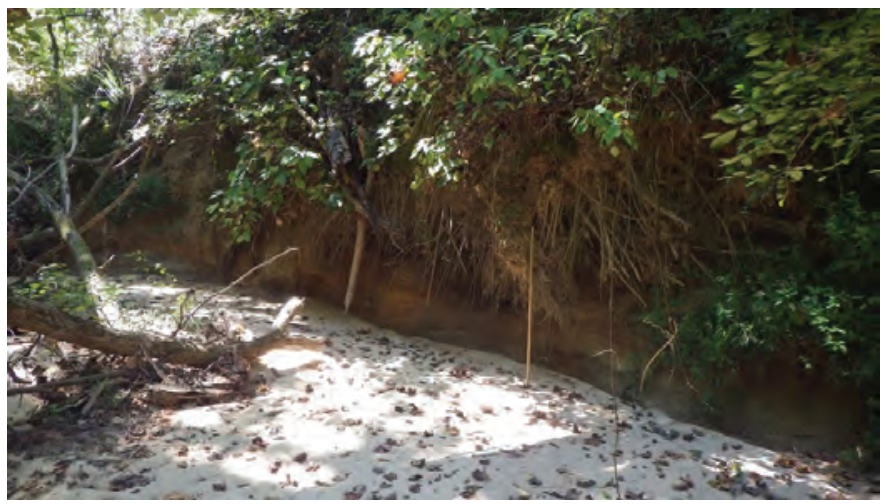

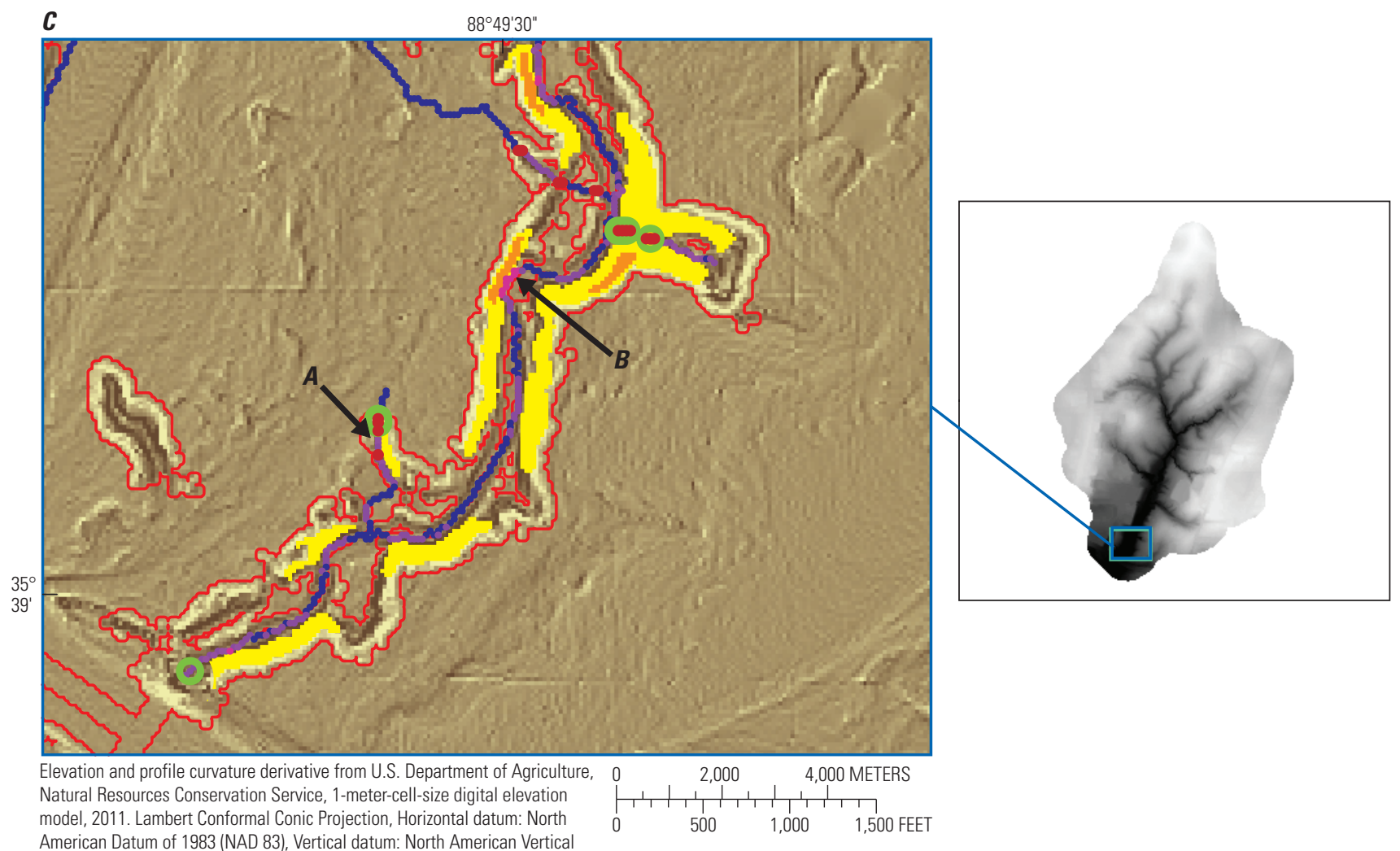

American Datum of 1983 (NAD 83). Vertical datum: North American Vertical Datum of 1988 (NAVD 88)

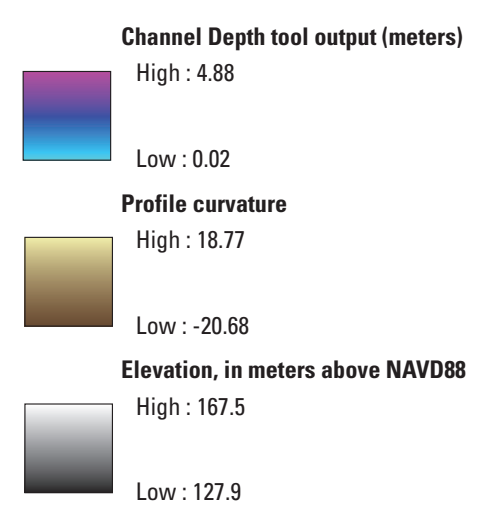

\section{EXPLANATION}

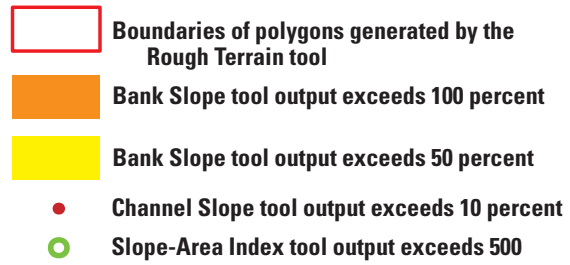

Figure 18. A, A tributary gully, and $B$, an overhanging bank, associated with, $C$, feature clusters of outputs from multiple tools, Upper Sandy study area. 


\section{Summary and Conclusions}

Identifying sites of geomorphic instability within stream-channel networks is a key component of watershed management and is particularly important for reducing suspended-sediment loads. Historically, investigations of stream-channel geomorphology—and of gully erosion in particular-have required time-intensive methods such as field surveys or visual analysis of aerial orthoimagery. More recently, high-resolution digital elevation models (DEMs) derived from airborne light detection and ranging (lidar) have enabled the identification of erosional and depositional features within stream-channel networks.

To improve the efficiency of DEM-based analysis, the U.S. Geological Survey conducted a pilot study in two contrasting study areas in West Tennessee to develop automated tools for identifying possible locations of geomorphic instability within stream-channel networks. The DEM Geomorphology Toolbox was developed for the study and contains seven tools to aid in the automated identification of stream-channel geomorphic features. Following acquisition and preprocessing of DEMs, stormwater-infrastructure locations were digitized in the field and used to modify the DEMs. Hydroconditioning was performed using the Optimized Pit Removal (OPR) tool (Jackson, 2013) to remove internal topographic depressions. Flow networks were derived using flow-accumulation thresholds of 1,000 and 5,000 cells from the culvert-modified, hydroconditioned DEMs. Field verification of tool outputs was performed in selected parts of both study areas and documented by photographs and field notes, with particular emphasis on identifying commission and omission errors in tool outputs. The Add Culverts tool and the Flow Network tool allow users to derive flow networks at user-specified flow-accumulation thresholds using preprocessed DEMs and vector files of stormwater infrastructure locations as inputs. Results from field verification efforts suggest that modifying DEMs on the basis of stormwater-infrastructure data can improve the accuracy of the derived flow networks. Those derived using flow-accumulation thresholds of 1,000 and 5,000 cells were both considerably more detailed than the high-resolution $(1: 24,000)$ flowlines included in the National Hydrography Dataset (NHD) (Simley and Carswell, 2009), including additional headwater reaches and many small tributaries not present in the NHD flowline.

The Bank Slope tool produces a raster of slope within a user-specified flow corridor surrounding an input flow network and a vector polygon file representing areas of bank slope exceeding the bank-slope threshold specified by the user. In eroded sections of stream-channel networks in both study areas, bank slopes commonly exceeded 50 percent and in some locations exceeded 100 percent. This tool successfully highlighted some areas of eroded and unstable streambank but failed to detect highly localized areas of steep slope that were probably too small to be resolved by 1-meter DEMs. In addition, the Bank Slope tool does not differentiate actively eroding streambanks from stable, vegetated streambanks of similar slope.

The Channel Depth tool employs a user-specified search radius to produce a channel depth raster representing the maximum elevation difference in the vicinity of each cell of an input flow network. High channel-depth values were associated with narrow, steep-walled gully systems. Rapid increases in channel depth values along the flow network were observed at gully heads. Locally decreasing channel-depth values were observed at the downstream ends of gully systems and at locations where the trench containing an active stream channel widened. Results from the Channel Depth tool are sensitive to the application of a fixed, user-specified search radius. Results do not correspond to bankfull depth at most locations, but nevertheless are useful for locating gully heads, alluvial fan heads, sections of channel adjacent to tall, actively eroding banks, and incised channels in gully systems.

The Channel Slope tool produces a channel slope raster containing slope values along an input flow network along with a vector point file representing the locations of channel slope greater than 2 percent. The Slope-Area Index (SAI) tool highlights points along an input flow network where the slope-area index (Vandaele and others, 1996; Daggupati and others, 2013) exceeds a user-specified threshold. The Channel Slope and Slope-Area Index tools were useful in identifying erosional features in both study areas, such as head cuts of varying sizes and morphologies. Field inspection indicated that some head cuts were neither detected by the Channel Slope tool nor the SAI tool. In other cases, high channel slope or SAI values were obtained in areas of the flow network having no observable signs of geomorphic instability. Users are advised to adjust input parameters and interpretation of tool outputs to balance errors of omission and commission depending on management applications and local geomorphic and hydrologic factors.

The Rough Terrain tool identifies areas within the input DEM that represent concentrations of high upward profile curvature (high convexity and high concavity) connected by steep slopes. In this study, such areas were commonly associated with gully systems that likely developed in agricultural fields and persisted under second-growth forest. The Rough Terrain tool processes data across the entire landscape, does not require an input flow network, and therefore is not sensitive to flow-network resolution unlike the other tools described in this report. Field verification of tool outputs suggests that the Rough Terrain tool identifies gullied areas as well as urban infrastructure features, such as stabilized steep embankments, retaining walls, and steep-sided ditches.

In both study areas, spatial overlaps in tool outputs (feature clusters) were apparent when multiple tools in the DEM Geomorphology Toolbox were run on the same input DEM. Feature clusters may be useful in prioritizing field investigations, because the clusters represent possible 
erosional features indicated by multiple complementary analytical methods. For example, large active gully heads were present in the study areas where multiple cells having high SAI values coincided with areas of high channel depth and high bank slope.

The tools in the DEM Geomorphology Toolbox were developed in two relatively small study areas having similar soils, geology, and physiography but contrasting land-use histories (one urban, one rural). Application of these tools to larger geographic areas or to different geologic or physiographic settings would require an iterative process involving field identification of geomorphic features of interest and adjustment of tool parameter settings to discriminate those features most effectively. For example, parameter settings such as the flow corridor width in the Bank Slope tool and search radius in the Channel Depth tool would need to be increased to effectively analyze larger channels. Parameter settings might also need to be adjusted on the basis of landscape characteristics such as land-use and disturbance history. For example, SAI thresholds for detecting ephemeral gullies may be lower in tilled agricultural fields than in undisturbed forested watersheds.

\section{References Cited}

Aksoy, H., and Kavvas, M., 2005, A review of hillslope and watershed scale erosion and sediment transport models: Catena, v. 64, p. 247-271.

Alonso, C.V., Bennett, S.J., and Stein, O.R., 2002, Predicting head cut erosion and migration in concentrated flows typical of upland areas: Water Resources Research, v. 38, no. 12, p. 39-1-39-15.

Biron, P.M., Choné, G., Buffin-Bélanger, T., Demers, S., and Olsen, T., 2013, Improvement of streams hydrogeomorphological assessment using LiDAR DEMs: Earth Surface Processes and Landforms, v. 38, p. 1808-1821.

Blackwood, D.C., 2012, Watershed management in West Tennessee, in 2012 Watershed symposium: Tennessee Water Resources Research Center, University of Tennessee, Knoxville, Tenn.

Booth, D.B., and Henshaw, P.C., 2001, Rates of channel erosion in small urban streams, in Wigmosta, M., and Burges, S. eds., Land use and watersheds-Human influence on hydrology and geomorphology in urban and forest areas: AGU Monograph Series, Water Science and Application, v. 2, p. 17-38.

Bradford, J.M., and Piest, R.F., 1980, Erosional development of valley-bottom gullies in the upper midwestern United States, in Coates, D.R. and Vitek, J.D. eds., Geomorphic thresholds: George Allen and Unwin, London, p. 75-101.
Broster, J., and Schneider, L., 1977, Settlement and subsistence: an analysis of Middle Woodland sites on the south fork of the Forked Deer River, West Tennessee: Journal of Alabama Archaeology, v. 23, no. 1, p. 58-69.

Brown, W., Keathley, G., and Conner, C., 1978, Soil survey of Madison County, Tennessee: U. S. Department of Agriculture Soil Conservation Service, 51 p.

Bull, L., and Kirkby, M., 1997, Gully processes and modelling: Progress in Physical Geography, v. 21, no. 3, p. 354-374.

Callow, J.N., Van Niel, K.P., and Boggs, G.S., 2007, How does modifying a DEM to reflect known hydrology affect subsequent terrain analysis?: Journal of Hydrology, v. 332, no. 1-2, p. 30-39.

Carswell, W.J., 2013, The 3D elevation program-Summary for Tennessee: U.S. Geological Survey Fact Sheet 20143008, 2 p.

Cartwright, J., and Diehl, T., 2016, Geomorphic and hydrologic data derived from digital elevation models in Madison County, Tennessee, in 2015: U.S. Geological Survey data release, accessed December 2, 2015, from www.sciencebase.gov at http://dx.doi.org/10.5066/ F7D50K20.

Chan, D., and Crabtree, S., 2014, Leveraging LiDAR for the field-NRCS-KY tools overview: Presentation to the Kentucky Agricultural Monitoring Committee on December 9, 2014, U.S. Department of Agriculture Natural Resources Conservation Service, accessed August 12, 2015, at http://ky.water.usgs.gov/projects/ky_ag_monitoring_ committee/ppts_12092014_mtg/NRCS.KASMC Executive Meeting 2014 Presentation.pdf.

Charlton, M.E., Large, A.R., and Fuller, I.C., 2003, Application of airborne lidar in river environmentsThe River Coquet, Northumberland, UK: Earth Surface Processes and Landforms, v. 28, p. 299-306.

City of Jackson, 2015, City of Jackson, Tennessee, property search application: Accessed October 14, 2015, at http:// tn.jackson.geopowered.com/.

Cocker, M.D., 2007, Geologic controls on erosion, sedimentation of streams, and potential for groundwater contamination in southwestern Georgia, in Proceedings of the 2007 Georgia Water Resources Conference: University of Georgia, Atlanta, Georgia, p. 3-6.

Conoscenti, C., Angileri, S., Cappadonia, C., Rotigliano, E., Agnesi, V., and Märker, M., 2014, Gully erosion susceptibility assessment by means of GIS-based logistic regression-A case of Sicily (Italy): Geomorphology, v. 204, p. 399-411. 
Cubanski, P., 2013, Stormwater watershed delineation, analyses, and regulatory requirements; County of Monterey: Watershed Management Experiential Learning for USDA Careers, Monterey, California, 17 p.

Dabney, S., Yoder, D., Vieira, D., Bingner, R., and Wells, R., 2010, Scaling a representative storm sequence to estimate ephemeral gully erosion with RUSLE2, in 2nd Joint Federal Interagency Conference: Las Vegas, Nevada, p. 9.

Daggupati, P., Douglas-Mankin, K., and Sheshukov, A., 2013, Predicting ephemeral gully locations and length using topographic index models: Transactions of the American Society of Agricultural and Biological Engineers, v. 56, no. 4, p. 1427-1440.

DeLong, S.B., Johnson, J.P.L., and Whipple, K.X., 2014, Arroyo channel head evolution in a flash-flood-dominated discontinuous ephemeral stream system: Geological Society of America Bulletin , v. 126 , no. 11-12 , p. 1683-1701.

Desmet, P., Poesen, J., Govers, G., and Vandaele, K., 1999, Importance of slope gradient and contributing area for optimal prediction of the initiation and trajectory of ephemeral gullies: Catena, v. 37, p. 377-392.

Dewberry, 2011, Final report of the National Enhanced Elevation Assessment: Fairfax, Virginia, Dewberry, 84 p.

Dewberry, 2012, Tennessee LiDAR: Report produced for the U.S. Army Corps of Engineers: USACE, TO\# 0001, St. Louis, Misouri, 164 p.

Dougall, C., Carroll, C., Herring, M., and Trevithick, R., 2007, Sednet modelling in the Fitzroy Basin (2007); spatially variable ground cover and revised gully layers can potentially generate significant changes in erosion sources and patterns, in Oxley, L. and Kulasiri, D. eds., MODSIM 2007, International Congress on Modelling and Simulation: Modelling and Simulation Society of Australia and New Zealand [Proceedings], p. 881-887.

Esri, 2015, GIS dictionary: Accessed January, 12, 2015, at http://support.esri.com/en/knowledgebase/Gisdictionary/ browse.

Eustace, A., Pringle, M., and Witte, C., 2009, Give me the dirt-Detection of gully extent and volume using high-resolution Lidar, in Jones, S., and Reinke, K., eds., Innovations in remote sensing and photogrammetry: Berlin and Heidelberg, Springer-Verlag, p. 255-269.

Fenneman, N., and Johnson, D., 1946, Physical divisions of the United States: U.S. Geological Survey map prepared in cooperation with the Physiographic Commission, scale $1: 7,000,000$.
Ferencevic, M., and Ashmore, P., 2012, Creating and evaluating digital elevation model-based stream-power map as a stream assessment tool: River Research and Applications, v. 28, p. 1394-1416.

Fitzpatrick, F., Waite, I.R., D’Arconte, P.J., Meador, M.R., Maupin, M., and Gurtz, M.E., 1998, Revised methods for characterizing stream habitat in the National Water-Quality Assessment Program: U.S. Geological Survey WaterResources Investigations Report 98-4052, 68 p.

Franklin, S., 2001, Remote sensing for sustainable forest management: Boca Raton, Florida, CRC Press, LLC., 409 p.

Hansen, W.F., 2001, Identifying stream types and management implications: Forest Ecology and Management, v. 143, no. 1-3, p. 39-46.

Happ, S.C., Rittenhouse, G., and Dobson, G.C., 1940, Some principles of accelerated stream and valley sedimentation: U.S Department of Agriculture Technical Bulletin 695.

Happ, S., Rittenhouse, G., and Dobson, G., 1975, Valley sedimentation as a factor in sediment-yield determinations, in Meyer, L., Foster, G., and Romkens, M. eds., Present and prospective technology for predicting sediment yields and sources, ARS S-40: Oxford, Miss., U.S. Department of Agriculture Agricultural Research Service.

Hardeman, W.D., Miller, R.A., and Swingle, G.D., 1966, Geologic map of Tennessee: State of Tennessee, Department of Conservation, Division of Geology.

Harrelson, C., Rawlins, C.L., and Potyondy, J., 1994, Stream channel reference sites-An illustrated guide to field technique: Fort Collins, Colo., U.S. Department of Agriculture, Forest Service, General Technical Report RM-245, 61 p.

Harvey, A.M., 2012, The coupling status of alluvial fans and debris cones-A review and synthesis: Earth Surface Processes and Landforms, v. 37, no. 1, p. 64-76.

Heideman, H.K., 2014, Lidar base specification (ver. 1.2): U.S. Geological Survey Techniques and Methods, book. 11, chap. B4, 67 p., with appendixes.

Heine, R., Lant, C., and Sengupta, R., 2004, Development and comparison of approaches for automated mapping of stream channel networks: Annals of the Association of American Geographers, v. 94, no. 3, p. 477-490.

Henley, W., Patterson, M., Neves, R., and Lemly, A., 2000, Effects of sedimentation and turbidity on lotic food webs: a concise review for natural resource managers: Reviews in Fisheries Science, v. 8, no. 2, p. 125-139.

Hessel, R., and Van Asch, T., 2003, Modelling gully erosion for a small catchment on the Chinese Loess Plateau: Catena, v. 54, p. 131-146. 
Höfle, B., Griesbaum, L., and Forbriger, M., 2013, GISbased detection of gullies in terrestrial LiDAR data of the Cerro Llamoca peatland (Peru): Remote Sensing, v. 5, p. 5851-5870.

Hogan, D.M., Jarnagin, S.T., Loperfido, J.V., and Van Ness, K., 2014, Mitigating the effects of landscape development on streams in urbanizing watersheds: Journal of the American Water Resources Association, v. 50, no. 1, p. 163-178.

Jackson, S., 2013, Optimized pit removal tutorial, version 1.5.1: Austin, Texas, University of Texas, Center for Research in Water Resources, $17 \mathrm{p}$.

James, L.A., Watson, D.G., and Hansen, W.F., 2007, Using LiDAR data to map gullies and headwater streams under forest canopy—South Carolina, USA: Catena, v. 71, no. 1, p. 132-144.

Jenson, S.K., 1991, Applications of hydrologic information automatically extracted from digital elevation models: Hydrological Processes, v. 5, p. 31-44.

Jenson, S.K., and Domingue, J.O., 1988, Extracting topographic structure from digital elevation data for geographic information system analysis: Photogrammetric Engineering and Remote Sensing, v. 54, no. 11, p. 1593-1600.

Jones, K.L., Poole, G.C., O’Daniel, S.J., Mertes, L., and Stanford, J., 2008, Surface hydrology of low-relief landscapes: assessing surface water flow impedance using LIDAR-derived digital elevation models: Remote Sensing of Environment, v. 112, no. 11, p. 4148-4158.

Katz, H.A., Daniels, J.M., and Ryan, S., 2014, Slope-area thresholds of road-induced gully erosion and consequent hillslope-channel interactions: Earth Surface Processes and Landforms, v. 39, no. 3, p. 285-295.

Kenny, F., Matthews, B., and Todd, K., 2008, Routing overland flow through sinks and flats in interpolated raster terrain surfaces: Computers and Geosciences, v. 34, p. $1417-1430$.

Kirkby, M., and Bracken, L., 2009, Gully process and gully dynamics: Earth Surface Processes and Landforms, v. 34, p. 1841-1851.

Ladd, D.E., and Law, G.S., 2007, Tennessee StreamStats—A web-enabled geographic information system application for automating the retrieval and calculation of streamflow statistics: U.S. Geological Survey Fact Sheet 2007-3081, $2 \mathrm{p}$.

Lawler, D., 1993, The measurement of river bank erosion and lateral channel change-A review: Earth Surface Processes and Landforms, v. 18, p. 777-821.
Li, R., Tang, Z., Li, X., and Winter, J., 2013, Drainage structure datasets and effects on LiDAR-derived surface flow modeling: ISPRS International Journal of Geo-Information, v. 2, no. 4, p. 1136-1152.

Lu, H., Moran, C.J., Prosser, I.P., and DeRose, R., 2004, Investment prioritization based on broadscale spatial budgeting to meet downstream targets for suspended sediment loads: Water Resources Research, v. 40, no. W09501, p. 16.

Mainfort, R., 1988, Middle Woodland ceremonialism at Pinson Mounds, Tennessee: American Antiquity, v. 53, no. 1 , p. $158-173$.

Mainfort, R.C., Kwas, M.L., and Mickelson, A.M., 2011, Mapping never-never land-An examination of Pinson Mounds cartography: Southeastern Archaeology, v. 30, no. 1 , p. $148-165$.

Martínez-Casasnovas, J., 2003, A spatial information technology approach for the mapping and quantification of gully erosion: Catena, v. 50, p. 293-308.

Martz, L.W., and Garbrecht, J., 1999, An outlet breaching algorithm for the treatment of closed depressions in a raster DEM: Computers and Geosciences, v. 25, no. 7, p. $835-844$.

Merritt, W.S., Letcher, R.A., and Jakeman, A.J., 2003, A review of erosion and sediment transport models: Environmental Modelling and Software, v. 18, p. 761-799.

Montgomery, D., and Dietrich, W., 1992, Channel initiation and the problem of landscape scale: Science, v. 255, no. 5046, p. 826-830.

Montgomery, D.R., and Foufoula-Georgiou, E., 1993, Channel network source representation using digital elevation models: Water Resources Research, v. 29, no. 12, p. 39253934.

Norton, D., Wickham, J., Wade, T., Kunert, K., Thomas, J., and Zeph, P., 2009, A method for comparative analysis of recovery potential in impaired waters restoration planning: Environmental Management, v. 44, p. 356-368.

Nyssen, J., Poesen, J., Veyret-Picot, M., Moeyersons, J., Haile, M., Deckers, J., Dewit, J., Naudts, J., Teka, K., and Govers, G., 2006, Assessment of gully erosion rates through interviews and measurements-A case study from northern Ethiopia: Earth Surface Processes and Landforms, v. 31, no. 2, p. 167-185.

O’Callaghan, J.F., and Mark, D.M., 1984, The extraction of drainage networks from digital elevation data: Computer Vision, Graphics, and Image Processing, v. 27, no. 2, p. 247. 
Ogren, B.M., 2012, Precision conservation in the Zumbro river watershed using LiDAR and digital terrain analysis to identify critical areas associated with water resource impairment in agricultural landscapes: Papers in Resource Analysis, v. 14, p. 15.

Pederson, D., 2015, Tennessee awarded USGS 3DEP Lidar grant, in TNGIC Today quarterly newsletter: Tennessee Geographic Information Council, Inc., p. 2-2.

Perroy, R.L., Bookhagen, B., Asner, G.P., and Chadwick, O., 2010, Comparison of gully erosion estimates using airborne and ground-based LiDAR on Santa Cruz Island, California: Geomorphology, v. 118, no. 3-4, p. 288-300.

Pierce, A., and King, S., 2007, The influence of valley plugs in channelized streams on floodplain sedimentation dynamics over the last century: Wetlands, v. 27, no. 3, p. 631-643.

Poesen, J., 2011, Challenges in gully erosion research: Landform Analysis, v. 17, p. 5-9.

Poesen, J., Nachtergaele, J., Verstraeten, G., and Valentin, C., 2003, Gully erosion and environmental change: Importance and research needs: Catena, v. 50, no. 2-4, p. 91-133.

Poesen, J.W., Torri, D.B., and Vanwalleghem, T., 2011, Gully erosion: procedures to adopt when modelling soil erosion in landscapes affected by gullying, in Morgan, R. and Nearing, M. eds., Handbook of erosion modelling: Oxford, U.K., Blackwell, p. 360-386.

Poppenga, S.K., Worstell, B.B., Stoker, J.M., and Greenlee, S.K., 2009, Comparison of surface flow features from Lidar-derived digital elevation models with historical elevation and hydrography data for Minnehaha County, South Dakota: U.S. Geological Survey Scientific Investigations Report 2009-5065, 34 p.

Poppenga, S.K., Worstell, B.B., Stoker, J.M., and Greenlee, S.K., 2010, Using selective drainage methods to extract continuous surface flow from 1-meter lidar-derived digital elevation data: U.S. Geological Survey Scientific Investigations Report 2010-5059, 12 p.

Ribaudo, M.O., 1986, Reducing soil erosion-Offsite benefits: U.S. Department of Agriculture, Economic Research Service, Agricultural Economic Report No. 561, 24 p.

Rieke-Zapp, D.H., and Nichols, M.H., 2011, Headcut retreat in a semiarid watershed in the southwestern United States since 1935: Catena, v. 87, no. 1, p. 1-10.

Roberts, J.K., and Collins, R.L., 1926, The Tertiary of west Tennessee: American Journal of Science, v. 69, p. 235-243.

Rustomji, P., 2006, Analysis of gully dimensions and sediment texture from southeast Australia for catchment sediment budgeting: Catena, v. 67, p. 119-127.
Saksa, M., and Minár, J., 2012, Assessing the natural hazard of gully erosion through a Geoecological Information System (GeIS) - A case study from the Western Carpathians: Geografie, v. 117, no. 2, p. 152-169.

Schumm, S., 1979, Geomorphic thresholds: the concept and its applications: Transactions of the Institute of British Geographers, p. 485-515.

Shellberg, B.J.G., and Brooks, A.P., 2013, Alluvial gully prevention and rehabilitation options for reducing sediment loads in the Normanby catchment and Northern Australia: Griffith University, Australian Rivers Institute, 314 p.

Simley, J.D., and Carswell Jr., W.J., 2009, The National Map-Hydrography: U.S. Geological Survey Fact Sheet, 2009-3054, 4 p.

Smiley, P., Knight, S., Shields, D., and Cooper, C., 2009, Influence of gully erosion control on amphibian and reptile communities within riparian zones of channelized streams: Ecohydrology, v. 2, p. 303-312.

Snyder, G., 2012, National enhanced elevation assessment at a glance: U.S. Geological Survey Fact Sheet 2012-3088, 2 p.

Soil Science Society of America, 2008, Glossary of soil science terms: Accessed December 7, 2015, at https://www. soils.org/publications/soils-glossary.

Svoray, T., Michailov, E., Cohen, A., Rokah, L., and Sturm, A., 2012, Predicting gully initiation-Comparing data mining techniques, analytical hierarchy processes and the topographic threshold: Earth Surface Processes and Landforms, v. 37, p. 607-619.

Taguas, E.V, Yuan, Y., Bingner, R., and Gomez, J., 2012, Modelling the contribution of ephemeral gully erosion under different soil managements-A case study in an olive orchard microcatchment using the AnnAGNPS model: Catena, v. 98, p. 1-16.

Thrush, S.F., Hewitt, J.E., Cummings, V.J., Ellis, J.I., Hatton, C., Lohrer, A., and Norkko, A., 2004, Muddy waters-Elevating sediment input to coastal and estuarine habitats: Frontiers in Ecology and the Environment, v. 2, no. 6, p. 299-306.

Trimble, S.W., 2008, Happ, S.C., Rittenhouse, G. and Dobson, G.C. 1940: Some principles of accelerated stream and valley sedimentation: U.S. Department of Agriculture Technical Bulletin 695: Progress in Physical Geography, v. 32, no. 3, p. 337-345. [Technical Bulletin 695 republished in Progress in Physical Geography serial as part of "Classics in physical geography revisited" series.]

U.S. Environmental Protection Agency, 2012, Identifying and protecting healthy watersheds: concepts, assessments, and management approaches: U.S. Environmental Protection Agency, Washington, D.C., 296 p. 
Valentin, C., Poesen, J., and Li, Y., 2005, Gully erosionImpacts, factors, and control: Catena, v. 63, p. 132-153.

Vandaele, K., Poesen, J., Govers, G., and Van Wesemael, B., 1996, Geomorphic threshold conditions for ephemeral gully incision: Geomorphology, v. 16, no. 2, p. 161-173.

Vandekerckhove, L., Poesen, J., and Govers, G., 2003, Medium-term gully headcut retreat rates in Southeast Spain determined from aerial photographs and ground measurements: Catena, v. 50, p. 329-352.

Vandekerckhove, L., Poesen, J., Oostwoud Wijdenes, D., and de Figueiredo, T., 1998, Topographical thresholds for ephemeral gully initiation in intensively cultivated areas of the Mediterranean: Catena, v. 33, p. 271-292.

Vandekerckhove, L., Poesen, J., Oostwoud Wijdenes, D., and Gyssels, G., 2001, Short-term bank gully retreat rates in Mediterranean environments: Catena, v. 44, p. 133-161.
Venner, M., 2014, Culvert management case studiesVermont, Oregon, Ohio, and Los Angeles County: U.S. Department of Transportation, Federal Highway Administration, 49 p.

Wantzen, K., 2006, Physical pollution-Effects of gully erosion benthic invertebrates in a tropical clear-water stream: Aquaric Conservation: Marine and Freshwater Ecosystems, v. 16, p. 733-749.

Weiss, A., 2001, Topographic position and landforms analysis: Poster presentation, ESRI User Conference, San Diego, California.

Wood, P.J., and Armitage, P.D., 1997, Biological effects of fine sediment in the lotic environment: Environmental Management, v. 21, no. 2, p. 203-217. 


\section{Glossary}

Glossary definitions marked with an asterisk (*) are direct quotations from the references cited; definitions without an asterisk were adapted from the references cited.

alluvial fan A wedge-shaped deposit of recent stream alluvium (transported sediment) that radiates outward and downslope as, in plan view, an open fan from a site draining an area of high relief or topography, such as the mouth of a valley, onto a gentler slope, typically an alluvial plain; the deposit is thickest at the fan apex, near the valley mouth, and thins to a feather edge at the terminus of the fan (W. Osterkamp, U.S. Geological Survey, written commun., 2015).

alluvium Sediment deposited by flowing water in a streambed, delta, or on a floodplain or other bottomland feature during comparatively recent geologic time (W. Osterkamp, U.S. Geological Survey, written commun., 2015).

artifact An inaccurate result or artificial anomaly introduced into a surface model, such as a DEM, resulting from a data manipulation process (Heideman, 2014).

braided stream* [A stream] with a wide, relatively horizontal channel bed over which water during low flows forms an interlacing pattern of splitting into numerous small conveyances that again coalesce a short distance downstream (W. Osterkamp, U.S. Geological Survey, written commun., 2015).

cell* A single element of a raster dataset. Each cell contains a single numeric value of information representative of the area covered by the cell (Heideman, 2014).

channel* A natural, or constructed, passageway or depression of perceptible linear extent containing continuously or periodically flowing water and sediment, or a connecting link between two bodies of water (W. Osterkamp, U.S. Geological Survey, written commun., 2015). Used in this report as a synonym for stream channel.

channel incision Lowering of a channel bed; also known as downcutting. circular neighborhood The two-

dimensional space around a point that includes all locations at a distance from the point less than or equal to $r$, where $r$ is the radius of the circle defining the outer boundary of the circular neighborhood.

commission error A false positive in the context of remote sensing (Franklin, 2001); used in this report to refer to tool outputs indicating possible locations of geomorphic instability that do not show signs of instability indicated by field inspection.

culvert* A tunnel carrying a stream or open drainage under a road or railroad, or through another type of obstruction to natural drainage. Typically, constructed of formed concrete or corrugated metal and surrounded on all sides, top, and bottom by earth or soil (Heideman, 2014).

deposition The constructive process of sediment accumulation into beds or irregular masses, especially the mechanical settling of sediment from suspension or tractive movement in water (W. Osterkamp, U.S. Geological Survey, written commun., 2015).

digital elevation model (DEM)* The digital cartographic representation of the elevation of the land at regularly spaced intervals in $\mathrm{x}$ and y directions, using $\mathrm{z}$ values referenced to a common vertical datum (Heideman, 2014).

entrenched channel A confined channel that is not connected to a floodplain.

ephemeral gully* A gully, typically in an agricultural field, that develops due to water erosion during a growing season but which is subject to removal by any primary tillage operation (W. Osterkamp, U.S. Geological Survey, written commun., 2015).

ephemeral stream A stream characterized by inconsistent or infrequent streamflow within a normally dry channel; except during periods of streamflow, the channel bed is directly underlain by unsaturated alluvium (W. Osterkamp, U.S. Geological Survey, written commun., 2015). 
erosion* The detachment and movement of soil or rock by water, wind, ice, or gravity (Soil Science Society of America, 2008).

floodplain* A strip of relatively smooth land bordering a stream incision, built of sediment carried by the stream and dropped in slackwater beyond the influence of the swift current of the channel (W. Osterkamp, U.S. Geological Survey, written commun., 2015).

flow corridor In the context of this report, an area of user-specified width within or surrounding the active channel, applied consistently across the study area within which the user may apply a tool.

focal mean The mean (average) value of raster cell values within a specified distance or neighborhood surrounding an input raster cell.

geomorphic instability A landform property marked by erosion or deposition at rates that are rapid relative to the surrounding landscape.

geomorphology* The study of landforms including, in recent times especially, investigations into the processes that cause and alter the landforms (W. Osterkamp, U.S. Geological Survey, written commun., 2015).

gully In the context of this report, a small, steep-sided channel cut in unconsolidated materials by an ephemeral stream. The gullies in this study are permanent gullies rather than ephemeral gullies; that is, they are not obliterated by field cultivation, but rather, remain as long-term landscape features. The sides of gullies are defined by steep slopes that represent either the edges of stream terraces (terrace slopes) or the sides of the valley (valley walls). Some of the gullies mentioned in this report have narrow bottoms occupied entirely by the stream channel, whereas others have wider gully bottoms that include discontinuous floodplains.

head cut An abrupt, steep step in the thalweg profile of a channel at which the stream has sufficient power to erode the bed, occurring both at the upstream end of gullies and along incising channels.

\section{hydroconditioning (hydrologic}

conditioning) A process by which elevation values are modified to produce coherent flow directions and flow accumulations. In particular, hydroconditioning requires the removal of internal topographic depressions (raster cells of low elevation completely surrounded by cells of higher elevations). light detection and ranging (lidar) An active remote-sensing technology that uses laser scanning to generate high-resolution elevation data over large areas.

omission error A false negative in the context of remote sensing (Franklin, 2001); used in this report to refer to locations of geomorphic instability identified by field inspection that were not identified by tool outputs.

parameter In the context of this report, a user-specified tool setting that helps define a tool's behavior as it is run (Esri, 2015).

permanent gully* A channel resulting from erosion and caused by the concentrated but intermittent flow of water, usually during and immediately following heavy rains. Permanent gullies are deep enough (usually $>0.5$ meters) to interfere with, and not to be obliterated by, normal tillage operations (Soil Science Society of America, 2008).

profile curvature Curvature in the direction of steepest slope; curvature is the second derivative of elevation (the slope of slope).

raster A type of geospatial data structure composed of a spatially continuous array of equally sized cells, with each cell containing a single piece of numeric information representative of the area covered by the cell (Heideman, 2014; Esri, 2015).

sediment Transported and deposited particles or aggregates derived from rocks, soil, or biological material (Soil Science Society of America, 2008).

stormwater infrastructure In the context of this report, man-made structures installed for the purpose of routing runoff from precipitation; especially culverts but also including ditches and storm sewers.

stream power A physical variable that represents the rate at which potential energy is expended in a stream channel as water flows downstream (Ferencevic and Ashmore, 2012).

valley plug A location within a channel where flow is blocked by sediment deposition, forcing floodwater and suspended sediment out of the channel and onto the floodplain (see Pierce and King, 2007).

vector A type of geospatial data structure, with subtypes including points, lines, and polygons, that is geometrically described by coordinate pairs (Heideman, 2014; Esri, 2015). 


\section{Appendix 1. Prospectus for Tool Application to Larger Geographic Areas}

The tools in the digital elevation model (DEM) Geomorphology Toolbox that are described in this report were developed and calibrated in two relatively small study areas. As a result, additional field verification and tool calibration would be required for these tools to be applied to larger geographic areas. This appendix contains a prospectus intended to support future planning and implementation efforts for tool application to geographic areas beyond the scope of this pilot study. Field verification resources were estimated for the study areas for the scope of field work described in this report and were compared across study areas. A generalized work plan was developed, itemizing the steps that would be required for tool application to other geographic areas.

\section{Field-Verification Resources}

Field-verification resources were estimated for both study areas in terms of hours spent on field verification of flow networks and tool outputs (table 1-1). Field verification of flow networks was considerably more resource-intensive in the Upper Sandy study area (8.5 person-hours spent to cover a 1.8-square-kilometer $\left[\mathrm{km}^{2}\right]$ study area containing 11 kilometers [km] of roads) compared to the Pinson Mounds study area (7.0 person-hours for a $13.6-\mathrm{km}^{2}$ study area containing $25 \mathrm{~km}$ of roads). Field verification of tool outputs was also more resource-intensive in the Upper Sandy study area (9.5 person-hours spent to cover an 8,600-square-meter $\left[\mathrm{m}^{2}\right]$ study area containing 2,500 meters [m] of flow network) compared to the Pinson Mounds study area (12.5 person-hours for a 20,600 $\mathrm{m}^{2}$ study area containing 5,500 $\mathrm{m}$ of flow network). In fact, field verification of tool outputs was conducted almost twice as quickly in the Pinson Mounds area (approximately $440 \mathrm{~m}$ of flow network inspected per hour) as in the Upper Sandy area (approximately $265 \mathrm{~m}$ per hour).

The differences in field-verification resources between the two study areas reflect differences in a number of practical and logistical constraints. Accessibility is an important determinant of field-verification resource requirements and includes considerations such as the distance between parking areas and the field features to be inspected, the topography of the terrain that must be navigated, the density and type of vegetation cover, and the access permission granted by private landowners. In several respects, the Pinson Mounds study area was more accessible than the Upper Sandy study area. For example, the Pinson Mounds study area has a relatively sparse understory, whereas the Upper Sandy study area has a greater density of brush and kudzu that impedes access and visibility. Season is an important consideration in planning field-verification efforts, because dense vegetation obstructs observation and movement.

Another set of determinants of resource requirements, especially for field verification of flow networks, is the number, spatial arrangement, and accessibility of stormwater infrastructure features. In general, urban or suburban watersheds are likely to require more field effort than agricultural or forested watersheds to digitize the locations of stormwater infrastructure features, because of the number and complexity of culverts and other infrastructure features.

Table 1-1. Field verification resources used in tool development and calibration for two study areas.

[Field verification of tool outputs was performed using flow networks derived with a 5,000-cell flow accumulation threshold. km, kilometer; $\mathrm{km}^{2}$, square kilometer; m, meter; $\mathrm{m}^{2}$, square meter]

\begin{tabular}{lcc}
\hline \multicolumn{1}{c}{ Data category } & $\begin{array}{c}\text { Upper Sandy } \\
\text { study area }\end{array}$ & $\begin{array}{c}\text { Pinson Mounds } \\
\text { study area }\end{array}$ \\
\hline \multicolumn{1}{c}{ Flow network field verification } & \\
\hline Distance $(\mathrm{km})$ of roads in study area & 11 & 25 \\
$\begin{array}{lcc}\text { Size of study area }\left(\mathrm{km}^{2}\right) \\
\text { Number of culverts digitized }\end{array}$ & 58 & 13.6 \\
Person-hours spent on field verification & 8.5 & 70 \\
\hline \multicolumn{2}{c}{ Tool output field verification } & 7 \\
\hline Area $\left(\mathrm{m}^{2}\right)$ used for field verification & 8,600 & 20,600 \\
Distance $(\mathrm{m})$ of flow network inspected & 2,500 & 5,500 \\
Person-hours spent on field verification & 9.5 & 12.5 \\
\hline
\end{tabular}


In urban areas, for example, storm sewers commonly drain into complex subterranean networks of conveyances, the configuration and connectivity of which may not be readily apparent at the ground surface. In such cases, field inspections may require the use of flashlights and compasses to determine the orientation of subsurface pipes. By contrast, culverts under driveways and small roads in rural areas commonly have inlets and outlets that are easily visible from roadways. Digitization of stormwater infrastructure features is likely to be a rate limiting step in the process of flow-network delineation and verification. Indeed, digitizing these features on the basis of field inspection would probably create substantial barriers to tool application across large geographic areas, such as across multiple counties. As a result, if existing, high-precision digital datasets of stormwater infrastructure locations can be obtained from municipalities or other agencies, such data could greatly expedite the tool application process and could potentially enable tool application to large geographic areas.

Notably, the field resource estimates in table 1-1 do not account for all required activities associated with field verification. In particular, these estimates do not include time that was spent preparing for field work (compiling base layers for navigation), setting up or putting away field equipment, travelling to and between field sites, and processing field data. For this study, field notes were dictated as audio files and later transcribed. Transcription required approximately 10 hours for the Pinson Mounds study area and approximately 5 hours for the Upper Sandy study area. Additional post-field-data processing included inspection and, where needed, manual correction of Global Positioning System (GPS) locations for field photographs. It should also be noted that the study areas described in this report are not representative of West Tennessee as a whole, much less other physiographic areas. Study areas were selected partly on the basis of ease of access, especially a lack of barriers to entry based on land ownership. Additionally, the field areas used to verify tool outputs were relatively free of obstructions to navigation, such as dense vegetation, inundation, fences, or hazardous terrain.

\section{Work Plan}

Applying the tools in the DEM Geomorphology Toolbox that are described herein to geographic areas beyond the two study areas will generally involve the following steps:
1. Reconnaissance - Preliminary field visits are conducted at the proposed study site and available data layers are consulted to determine accessibility, road network density and configuration, land ownership, presence of dense vegetation and other possible obstacles.

2. DEM preparation - The DEM tiles for the study site are obtained, compiled, and preprocessed according to the steps itemized in the methods section of this report.

3. Derivation of preliminary flow networks-Using the tools described in this report, preliminary flow networks are derived from the DEM.

4. Field verification of preliminary flow networksPreliminary flow networks are inspected in the field, and vector line files are digitized representing culverts and other stormwater infrastructure.

5. Culvert modification-Using the files created in step 4, the DEM is modified and hydroconditioned, enabling derivation of modified flow networks using the tools described in this report.

6. Tool application-The tools applied in this report are applied to generate geomorphic indicators.

7. Spatial analysis - Outputs of tools applied in step 6 are mapped and spatially analyzed to determine locations having concentrations of features identified by multiple tools; such locations may be used to prioritize field inspection efforts.

8. Field inspection of tool outputs - Tool outputs from step 6 are inspected in the field and documented using photography and field notes, with special attention paid to commission errors (features identified by tools that do not correspond to signs of geomorphic instability as indicated by field inspection) and omission errors (field indicators of geomorphic instability that were not identified by tool outputs).

9. Tool calibration -Field data collected in step 8 are used to refine and calibrate tools to minimize occurrences of omission and commission errors. 
Publishing support provided by the U.S. Geological Survey

Science Publishing Network, Lafayette and Tacoma Publishing Service Centers

For more information concerning the research in this report, contact the Director, Lower Mississippi-Gulf Water Science Center U.S. Geological Survey 540 Grassmere Park, Suite 100 Nashville, Tennessee 37211 http://tn.water.usgs.gov/ 
